Andrews University

Digital Commons @ Andrews University

2015

\title{
A Biblical and Missiological Framework for Cross-Cultural \\ Mission: A Case Study of the Lobi Funeral Rites in Burkina Faso
}

Boubakar Sanou

Andrews University, sanou@andrews.edu

Follow this and additional works at: https://digitalcommons.andrews.edu/dissertations

Part of the Missions and World Christianity Commons

\section{Recommended Citation}

Sanou, Boubakar, "A Biblical and Missiological Framework for Cross-Cultural Mission: A Case Study of the Lobi Funeral Rites in Burkina Faso" (2015). Dissertations. 1572.

https://digitalcommons.andrews.edu/dissertations/1572

https://dx.doi.org/10.32597/dissertations/1572

This Dissertation is brought to you for free and open access by the Graduate Research at Digital Commons @ Andrews University. It has been accepted for inclusion in Dissertations by an authorized administrator of Digital Commons@ Andrews University. For more information, please contact repository@andrews.edu. 


\begin{abstract}
A BIBLICAL AND MISSIOLOGICAL FRAMEWORK FOR CROSS-CULTURAL MISSION: A CASE STUDY OF THE LOBI FUNERAL RITES IN BURKINA FASO
\end{abstract}

by

Boubakar Sanou

Adviser: Gorden R. Doss 


\section{ABSTRACT OF GRADUATE STUDENT RESEARCH}

Dissertation

Andrews University

Seventh-day Adventist Theological Seminary

Title: A BIBLICAL AND MISSIOLOGICAL FRAMEWORK FOR CROSSCULTURAL MISSION: A CASE STUDY OF THE LOBI FUNERAL RITES IN BURKINA FASO

Name of researcher: Boubakar Sanou

Name and degree of faculty adviser: Gorden R. Doss, PhD

Date completed: August 2015

\section{Problem}

Converts to Christianity in traditional contexts often face pressure to continue traditional rituals and practices which sometimes contain unbiblical elements. Nonselective performance of traditional practices can produce dual allegiance and syncretism. Such is the case with Lobi Seventh-day Adventists concerning their traditional funeral rites of passage. Some core elements of these traditional funeral rites, in which all community members are expected to fully participate, conflict with biblical teachings on the human condition after death. 


\section{Method}

This dissertation starts by laying the theoretical and theological basis for addressing the problem. The dissertation then uses ethnographic research of funeral rites among the Lobi people of Burkina Faso to understand the biblical and missiological issues they raise. The process of data collection during my field research was based on observation of people's behavior at a funeral ceremony and on a purposeful sampling of 16 participants for interviews to have a personal and deeper understanding of the Lobi cultural and religious contexts in relation to funeral rites. I interviewed three Lobi religious leaders, six Lobi Adventists who have taken part in traditional funeral rites before becoming Adventists, two Lobi Adventists who continue to take part in traditional funeral rites, four Lobi Adventists who are being pressured to participate in funeral rites, and a Lobi Catholic priest who has published on Lobi funeral rites.

\section{Results}

My findings broadened my understanding of the religious and sociocultural significance of the Lobi funeral rites as well as the challenges some traditional practices pose to those committed to being fully biblical Christians. A biblical and missiological framework was developed to address the challenges such traditional rites pose to Christian mission in general and to Seventh-day Adventist mission in particular.

\section{Conclusion}

Given that the number of converts to Christianity among the Lobi of Burkina Faso is only five percent of their population, the Joshua Project considers them to be an unreached people group. If more Lobi are to be won to Christ and become mature 
disciples, their real-life situations need to be understood and addressed both biblically and missiologically. A well-planned ethnographic study is helpful in reaching this goal. Biblical and missiological principles derived from such a process can also be generalized to other cross-cultural mission contexts. 


\author{
Andrews University \\ Seventh-day Adventist Theological Seminary
}

\title{
A BIBLICAL AND MISSIOLOGICAL FRAMEWORK FOR CROSS-CULTURAL MISSION: A CASE STUDY OF THE LOBI FUNERAL RITES IN BURKINA FASO
}

\author{
A Dissertation \\ Presented in Partial Fulfillment \\ of the Requirements for the Degree \\ Doctor of Philosophy
}

by

Boubakar Sanou

August 2015 
(C) Copyright by Boubakar Sanou 2015

All Rights Reserved 


\title{
A BIBLICAL AND MISSIOLOGICAL FRAMEWORK FOR CROSS-CULTURAL MISSION: A CASE STUDY OF THE LOBI FUNERAL RITES IN BURKINA FASO
}

\author{
A dissertation \\ presented in partial fulfillment \\ of the requirements for the degree \\ Doctor of Philosophy
}

by

Boubakar Sanou

APPROVAL BY THE COMMITTEE

Faculty Adviser,

Gorden R. Doss

Professor of Missions

Bruce L. Bauer

Professor of Missions

Teresa Reeve

Associate Professor of

New Testament

Stanley Patterson

Professor of Christian Ministry

Wilbert R. Shenk

Senior Professor of Mission History and Contemporary Culture
Director of $\mathrm{PhD} / \mathrm{ThD}$ Program

Thomas Shepherd

Dean, SDA Theological Seminary

Jiří Moskala

Date approved 
Kurt, Margaret, Sarah, Amy, and Eric Unglaub, Missionaries to the Lobi of Burkina Faso, 1993-2000 


\section{TABLE OF CONTENTS}

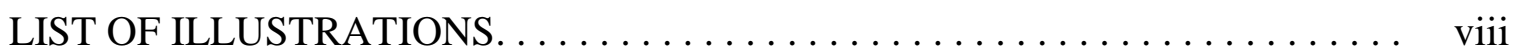

ACKNOWLEDGMENTS $\ldots \ldots \ldots \ldots \ldots \ldots \ldots \ldots \ldots \ldots \ldots \ldots \ldots \ldots \ldots \ldots$, ix

Chapter

1. OVERVIEW OF THE DISSERTATION $\ldots \ldots \ldots \ldots \ldots \ldots \ldots \ldots \ldots$

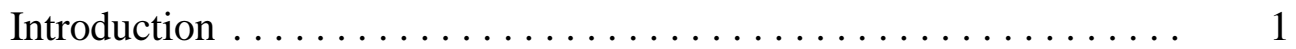

Background of the Study $\ldots \ldots \ldots \ldots \ldots \ldots \ldots \ldots \ldots \ldots \ldots \ldots$

Challenge to Christian Mission ...................... 5

Statement of the Problem........................ 8

Purpose Statement .......................... 8

Research Questions............................ 8

Justification for the Research . . . . . . . . . . . . . . . . . 9

Conceptual Framework $\ldots \ldots \ldots \ldots \ldots \ldots \ldots \ldots \ldots \ldots . \ldots \ldots$

Methodology............................... 12

Delimitation ............................... 13

Limitations .............................. 13

Dissertation Outline .......................... 13

2. RELIGIOUS AND SOCIO-CULTURAL ASPECTS OF THE LOBI

FUNERAL RITES.............................. 15

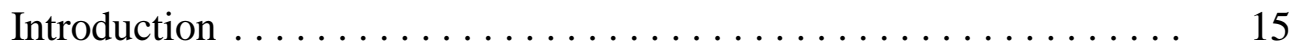

Socio-Cultural Context of the Lobi .................. 16

Brief History and Geographical Location . . . . . . . . . . 16

Social Organization ........................ 18

Community Life and Social Values. . . . . . . . . . . . . . . . 19

Status, Leadership, and Rites of Passage . . . . . . . . . . 20

Introduction to Rites of Passage....................... 21

Birth Rites among the Lobi ..................... 22

Initiation Rites among the Lobi $\ldots \ldots \ldots \ldots \ldots \ldots \ldots \ldots .23$

Marriage Rites among the Lobi .................. 28

Conceptual Background of Lobi Funeral Rites . . . . . . . . . . . 29

The Concept of God ......................... 29

Spirits ................................ 31

Ancestors .............................. 32

Lobi Funeral Rites of Passage $\ldots \ldots \ldots \ldots \ldots \ldots \ldots \ldots \ldots, \quad 38$ 


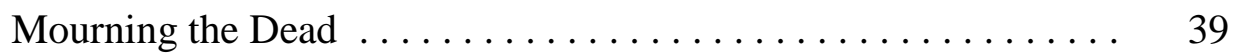

Finding the Cause of Death . . . . . . . . . . . . . . . 40

The Central Funeral Rites. . . . . . . . . . . . . . . . . . . 43

The First Funeral Rite....................... 44

The Second Funeral Rite $\ldots \ldots \ldots \ldots \ldots \ldots \ldots \ldots \ldots$

Conclusion ................................ 48

3. DEATH AND FUNERAL RITES OF PASSAGE IN THE BIBLE. . . . . . 51

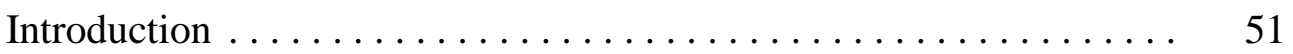

Cultural Contexts of the Bible ................... 51

Cultural Values of Community in the Old Testament ......... 52

Cultural Values of Community in the Early Church .......... 55

Biblical View of Life and Death .................. 58

The Nature of Humans and the State of the Dead in the Bible ... 58

The Gathering to One's Ancestors/People............... 63

Belief in the Afterlife........................... 67

The Resurrection of the Dead ..................... 69

Rituals and Cultural Practices Surrounding Death in Scripture...... 70

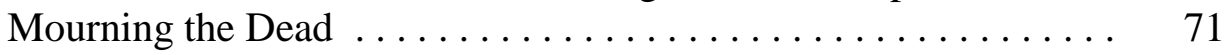

Burial Customs............................. 71

Baptism for the Dead ........................ 75

Forbidden Death-Related Rituals................. 80

Cutting One's Body for the Dead — Leviticus 19:28 . . . . . 80

Spiritism—Leviticus 20:6, 27; Deuteronomy 18:10-13..... 81

Shaving the Head for the Dead—Deuteronomy $14: 1-2 \ldots \ldots \quad 82$

Conclusion ............................... 83

4. RESEARCH FINDINGS AND CHALLENGES $\ldots \ldots \ldots \ldots \ldots \ldots \ldots$

Introduction ............................... 85

Description of Research Process ................... 85

Interviews with Lobi Religious Leaders. . . . . . . . . . . . 85

Interviews with Lobi Seventh-day Adventists........... 88

Members Who Took Part in Lobi Funeral Rites before

Conversion ............................ 88

Members Who Took Part/Are Taking Part in Lobi Funeral

Rites after Becoming Adventists ............... 91

Members Experiencing Pressure to Participate in Lobi

Funeral Rites........................... 93

Observation of Public Behavior at a Funeral . . . . . . . . . . . 94

Biblical and Missiological Challenges................... 96

The Fear of Evil Powers. . . . . . . . . . . . . . . . . . . . . . 96

Social Pressure ........................... 97

Poor Discipleship of Some Converts . . . . . . . . . . . . . . . 97

Lack of Worldview Change . . . . . . . . . . . . . . . . . . 98 
Inconsistency of Some Church Leaders . . . . . . . . . . . . .

5. A BIBLICAL AND MISSIOLOGICAL FRAMEWORK FOR RESPONDING TO THE LOBI FUNERAL RITES. . . . . . . . . . . . . . 101

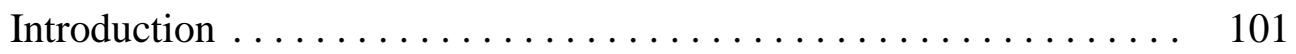

Critical Contextualization ........................ 102

God and Cultural Context of the Old Testament . . . . . . . . . . . . 104

Contextualization in the New Testament . . . . . . . . . . . 106

The Incarnation as a Foundation of Contextualization . . . . . 106

Christ as the Logos in John 1:1, $14 \ldots \ldots \ldots \ldots \ldots \ldots \ldots$

The Gospels . . . . . . . . . . . . . . . . . . . . . . . . . 109

The Jerusalem Council-Acts 15. . . . . . . . . . . . . . . . 109

Process of Critical Contextualization. . . . . . . . . . . . 110

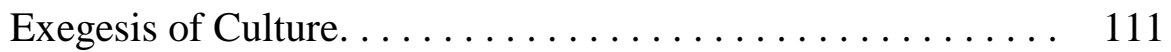

Exegesis of Scripture . . . . . . . . . . . . . . . . 112

Critical Response ...................... 112

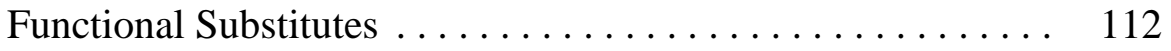

Transformational Ministry . . . . . . . . . . . . . 113

Minimizing the Risk of Religious Syncretism in Mission . . . . . . . . 113

Understanding Religious Syncretism. . . . . . . . . . . . . . 115

Factors Contributing to Religious Syncretism . . . . . . . . . . . 117

Growing Acceptance of Religious Pluralism........... 117

Mission Approaches to Other Religions and Cultures . . . . . . 119

Inadequate Discipling of New Converts. . . . . . . . . . 121

A Biblical Response to Religious Syncretism . . . . . . . . . . . . . 122

Emphasis on Discipleship. ................ 122

Long-term commitment to the spiritual welfare and

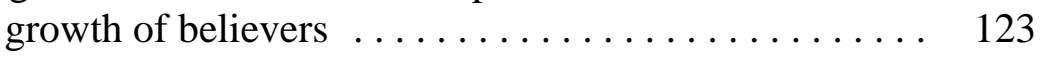

Modeling a spiritual walk with God ........... 123

Personal attention to believers' spiritual needs . . . . . . 124

The teaching of biblical truth $\ldots \ldots \ldots \ldots \ldots \ldots 124$

Dimensions of Biblical Discipleship . . . . . . . . . . 125

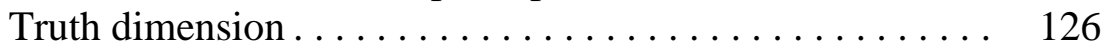

Allegiance dimension $\ldots \ldots \ldots \ldots \ldots \ldots \ldots \ldots \ldots \ldots \ldots$

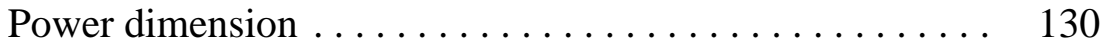

Toward a balanced approach $\ldots \ldots \ldots \ldots \ldots \ldots \ldots$

Theological and Missiological Perspectives on Culture . . . . . . . 139

Working Definition of Culture. . . . . . . . . . . . . . . 139

A Theological Perspective on Culture . . . . . . . . . . . . . . 140

A Missiological Perspective on Culture. . . . . . . . . . . . . . 143

Creating Functional Substitutes for Lobi Funeral Rites. . . . . . . . 148

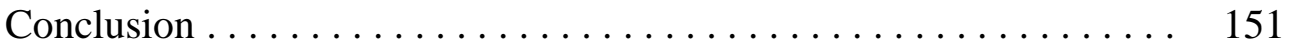


6. SUMMARY, CONCLUSION, AND RECOMMENDATIONS ........ 155

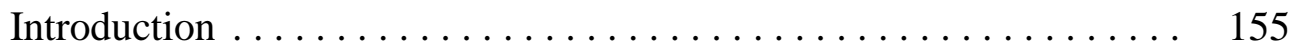

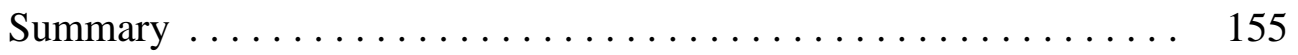

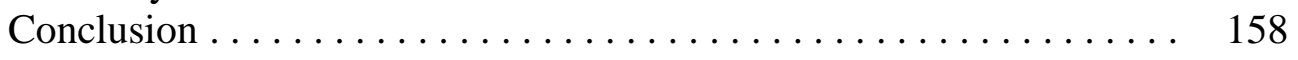

Recommendations ....................... 161

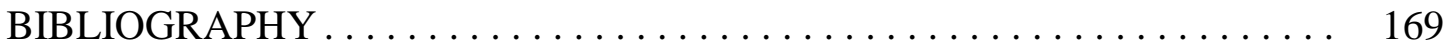




\section{LIST OF ILLUSTRATIONS}

1. Major Ethnic Groups of Burkina Faso. . . . . . . . . . . . . . . . 17

2. Discipleship Supported by Its Truth, Allegiance, and Power Dimensions ..... 137

3. The Relation between the Three Dimensions as Proposed by Charles Kraft . . . 137 


\section{ACKNOWLEDGMENTS}

My journey into the Doctor of Philosophy program began in August 2011. Without the help of God and the many people he used to help my family, this journey would have been impossible to accomplish.

I am grateful to God for all his provisions. The journey was difficult, sometimes unbearable financially and emotionally, but God has always come up with a way of rescue.

I express grateful thanks to Kady Sanou, my sister, for her love and support; Serge and Chantal Sanou, our first hosts in the United States; Linda Bauer, who has been a mother to my wife and me here in Berrien Springs, always tenderly caring for us; Bruce Bauer, Peter and Jacobus Van Bemmelen, Loren and Ann Hamel, Allain and Georgette Long, Rosemarie Anker, Steve Nash, Thomas Shepherd, Mabel Bowen, Bonnie Proctor, Cheryl and Gorden Doss, Norman Doss, John and Rubi Snell, Rudi Maier, Hyveth Williams, Yvonna Applewhite, Diana Rimoni, Emmanuel Harrison Takyi, Choi Gyeong Chun, Kelvin Onongha, Haron Matwetwe, Wagner Kuhn, Christon Arthur, Chiemela Ikonne, Marcellin and Esther Apiou, Claude and Katherine Apiou, Stéphane Saba, Philippe and Aïcha Apiou, Frédéric Apiou, Gérard and Sandrine Bayili, William H. Wright, Dafrassi Ouattara, Michael Adomako, Ugochukwu Elems, Emmanuel and Oluwabukola Abar, Michael and Enid Harris, Clément and Fati Fassinou, and the donors 
to the $\mathrm{PhD} / \mathrm{ThD}$ Scholarship Funds, for the various ways they have allowed God to use them to be a blessing to my family.

I am appreciative of the spiritual support of my prayer group partners Sami Kam, Sié Kam, Jean Jacques Manigni, Gérard Bayili, Gaston Ouédraogo, and Adamou Yoni. They have prayed faithfully for my family every single Monday.

Pastor Ben Issouf Ouédraogo and Abbé Hervé Sansan Pooda have been very instrumental in the success of my field research in Burkina Faso. Thank you very much.

Gorden Doss, Bruce Bauer, Teresa Reeve, and Stanley Patterson, my committee members, have challenged and channeled my thoughts. They have helped me to be balanced in thinking both biblically and missiologically. I am very grateful to them.

Finally, I am very thankful to my beloved wife, Sylvie, a true partner in ministry. She has always encouraged me to aim high for the glory of God. I am grateful for her love, support, and constant prayers. 


\section{CHAPTER 1}

\section{OVERVIEW OF THE DISSERTATION}

\section{Introduction}

This dissertation is a study of mission within the Lobi cultural context in Burkina Faso. The Lobi are an ethnic group living in three West African countries: southwestern Burkina Faso, northern Côte d'Ivoire, and western Ghana. The Lobi are predominantly ethno-religionists. ${ }^{1}$ This study aims at investigating the socio-cultural and religious significance associated with the Lobi funeral rites of passage, ${ }^{2}$ evaluating these cultural practices in the light of biblical teachings. It will then propose a biblical and missiological framework for responding to them in order to facilitate a full acceptance of the gospel and thus avoid syncretistic practices among Lobi Seventh-day Adventists. ${ }^{3}$

\footnotetext{
${ }^{1}$ The Joshua Project, an organization dedicated to reaching people groups with the gospel, gives the following statistics on the Lobi living in Burkina Faso: Population $(528,000)$, Evangelicals $(2.00 \%)$, and Christian adherents (5.00\%). Because the percentage of Evangelicals is only $2 \%$ and that of the Christian adherents is only 5\% among the Lobi, they are considered an unreached people group by the Joshua Project (accessed December 7, 2014, www.joshuaproject.net/ countries.php?rog3=UV).

${ }^{2}$ Catherine Bell, Ritual: Perspectives and Dimensions (New York: Oxford University Press, 1997), 94. She defines rites of passage as "ceremonies that accompany and dramatize such major events as birth, coming-of-age initiations for boys and girls, marriage, and death. Sometimes called 'life-crisis' or 'lifecycle' rites, they culturally mark a person's transition from one stage of social life to another."

${ }^{3}$ The Seventh-day Adventist Church is present in Burkina Faso since 1971. But it was only in 1992 that two Adventist Frontier missionaries (Kurt Unglaub and Herbert Prandl) took the SDA message to the Lobi. Their strategies consisted of establishing good rapport with villagers, helping them with basic needs, and then Bible studies followed. Their first converts were baptized in 1994. Today there are about 438 Lobi Seventh-day Adventists in Burkina Faso.
} 


\section{Background to the Study}

Prior to the advent of Christianity and Islam in Africa, the religious systems developed by Africans formed the basis of their social and cultural life. Although this has been to some extent modified by colonial and postcolonial experiences, these indigenous religions continue to exist alongside and sometimes within Christianity and Islam and to play an important role in daily experience. As most converts to Christianity are from the African Traditional Religions (ATR) background, "it is not uncommon to find Biblebelieving Christians in Africa reverting to unchristian practices from time to time, and especially, in times of felt needs and crises." ${ }^{4}$

Because the gospel is always received from within one's own cultural identity, ${ }^{5}$ those who leave ATR to join Christianity take with them, in large measure, their cultural worldview, which is heavily influenced by traditional beliefs. A convert to Christianity or Islam from an ATR background does not become a Christian or a Muslim with the same experiences and challenges as someone from another part of the world. Just like converts world-wide, African converts' new religious practices remain colored by the culture in which they grew up. This is so because when people come to Christ they are likely to interpret the Scriptures through the filter of their own worldview, thus often tending to be

${ }^{4}$ Zacchaeus Mathema, "Towards an Understanding of the African Worldview," in The Church, Culture and Spirits: Adventism in Africa, ed. Kwabena Donkor (Silver Spring, MD: Biblical Research Institute, General Conference of Seventh-day Adventists, 2011), 38. See also Alexander Jebadu, "Ancestral Veneration and the Possibility of its Incorporation into the Church," Exchange 36, no. 3 (2007): 246-247. According to him, the same religious phenomenon is also practiced in Asia, Latin America, Melanesia, and Australia (among the Aborigines).

${ }^{5}$ Timothy C. Tennent, Invitation to World Missions: A Trinitarian Missiology for the Twenty-first Century (Grand Rapids, MI: Kregel, 2010), 186. 
syncretistic by weaving non-biblical beliefs and practices from past religious systems into the beliefs and practices of Christianity. ${ }^{6}$

In general, rites of passage are seen as very important moments in the social and religious life of a community. Rituals related to funeral ceremonies, in particular, are of utmost significance as they are believed to maintain the relationship between the world of the living and that of the ancestors (the living dead). Together the living and their ancestors form an ongoing community. ${ }^{7}$ As such, the relation between the living and the dead stands out as one of the most fundamental features of traditional religious life. James Amanze points out that "it is commonly believed that the ancestors still live, though invisible, and that they are certainly present in the life of the individual and the community. ... They see everything, hear everything, are interested in the affairs of human beings, and wish, above everything else, to be remembered."8 The ancestors are believed to be the guarantors of life and well-being, ${ }^{9}$ the representatives of law, order,

${ }^{6}$ Gailyn Van Rheenen, Communicating Christ in Animistic Contexts (Pasadena, CA: William Carey Library, 1991), 95.

${ }^{7}$ Teresa Cruz e Silva and Ana Laforte, “Christianity, African Traditional Religions and Cultural Identity in Southern Mozambique," in Rites of Passage in Contemporary Africa: Interaction between Christian and African Traditional Religions, ed. James L. Cox (Cardiff, UK: Cardiff Academic Press, 1998), 37.

${ }^{8}$ James N. Amanze, "Christianity and Ancestors Veneration in Botswana," Studies in World Christianity 9, no. 1 (2003): 44.

${ }^{9}$ Aylword Shorter, "Conflicting Attitudes to Ancestor Veneration in Africa," African Ecclesial Review 11, no. 1 (January 1969): 29. See also Bolaji Idowu, African Traditional Religion: A Definition (London, UK: SCM Press, 1973), 193. 
and ethical values in the community, ${ }^{10}$ and the intermediaries between the living and God. ${ }^{11}$

African social structure also places an emphasis on community centeredness rather than individualism. A sense of community and humane living are highly cherished values of traditional African life. With this attitude toward life, it is "the community [that] makes and produces the individual. The individual has no existence of his own apart from the community's." 12 The following saying best describes this social structure, "I am, because we are; and since we are, therefore I am." ${ }^{13}$ Full membership in the community is synonymous with participating in its beliefs, ceremonies, rituals, and festivals; and "to be without one of these corporate elements of life is to be out of the whole picture." ${ }^{14}$ Because identification with the community is a primary virtue, individuals generally find fulfillment in as much as they belong. Eugene Hillman captures more vividly this sense of communal life in the following way:

In societies that are held together by strong kin relationships, individuality is rarely, if ever asserted as an explicit value in itself. The person is not generally seen in isolation from the community. Rather, his personal individuality is affirmed and

${ }^{10}$ John S. Mbiti, African Religions \& Philosophy (Oxford, UK: Heinemann, 1990), 82. Misfortune, illness, and death in the community are often interpreted as the sign of the ancestors' anger because of an individual or family's misconduct. Any time the ancestors' authority is questioned, they in turn question people's lives.

${ }^{11}$ Ignatius M. Zvarevashe, "The Problem of Ancestors and Inculturation," African Ecclesial Review 29, no. 4 (August 1987): 242. See also Edward Geoffrey Parrinder, Religion in Africa (Baltimore, MD: Penguin Books, 1969), 69. It is believed that "just as a chief is approached through an intermediary, so prayer may go to God through the ancestral spirits."

${ }^{12}$ Zablon Nthamburi, "Making the Gospel Relevant Within the African Context and Culture," African Ecclesial Review 25, no. 3 (June 1983): 163.

${ }^{13}$ Mbiti, African Religions and Philosophy, 106.

${ }^{14}$ Ibid., 2. Because in some instances this means being severed from one's context of security, it makes many converts to Christianity vulnerable to syncretism and dual allegiance. 
fulfilled only in relation to the good of others, and this is explicitly recognized as normative, to the extent that the individual is expected to follow the socially established patterns. In this sense, each man lives for others, and his personal development is always community-oriented. ${ }^{15}$

\section{Challenge to Christian Mission}

The above overview highlights the current challenge to Christian mission in the traditional African context. For Christian witness to be effective in this context, the presentation of the gospel must not only be biblically sound but also "culturally relevant and receiver-oriented thus minimizing rejection by and alienation of the people to whom it is presented." 16 Further, "because the gospel cannot be heard in the abstract apart from a cultural home," ${ }^{17}$ God must speak to an African as an African, and not as a Middle Easterner, a North American, or any other person outside of Africa.

Historically, Christian responses to the beliefs and practices of traditional religions have taken one of four main forms: displacement, accommodation, fulfillment, or substitution. ${ }^{18}$ The displacement paradigm "denies that there is anything that is of God in non-Christian religions." ${ }^{\prime 19}$ Its advocates judge every aspect of traditional religious beliefs and practices to be idolatrous, and thus anti-biblical, and require converts to

\footnotetext{
${ }^{15}$ Eugene Hillman, Polygamy Reconsidered: African Plural Marriage and the Christian Churches (New York: Orbis Books, 1975), 112.

${ }^{16}$ Boubakar Sanou, "Motivating and Training the Laity to Increase their Involvement in Ministry in the Ouaga-Center Adventist Church in Burkina Faso" (DMin diss., Andrews University, 2010), 42.

${ }^{17}$ Dean Flemming, Contextualization in the New Testament: Patterns for Theology and Mission (Downers Grove, IL: InterVarsity, 2005), 138.

${ }^{18}$ Henry N. Smith, “A Typology of Christian Responses to Chinese Ancestor Worship,” Journal of Ecumenical Studies 26, no. 4 (Fall 1989): 628.

${ }^{19}$ Jabulani A. Nxumalo, "Christ and Ancestors in the African World: A Pastoral Consideration," Journal of Theology for Southern Africa no. 32 (September 1980): 6.
} 
Christianity to make a complete conceptual and ritual break with them. They assume that there is religious incompatibility between Christianity and traditional practices. ${ }^{20}$

The accommodation model emphasizes the socio-ethical motives of traditional beliefs and practices and permits Christian converts to actively participate in them. ${ }^{21}$ The principle of accommodation presupposes the acknowledgment of neutral and naturally good elements in non-Christian ways of life and insists that such elements should be incorporated as an essential part of the local Christian community's behavior. ${ }^{22}$ In some contexts, this paradigm of mission often tends towards an uncritical acceptance of traditional practices by the church as part of people's cultural heritage that should be respected. ${ }^{23}$ As a result, it is susceptible to opening the door to syncretism as Christians continue to maintain beliefs and practices that stand in conflict with the gospel. ${ }^{24}$

The fulfillment model assumes that all the positive elements of traditional customs already exist in the Christian tradition in a higher form, and therefore views traditional rites as “a laudable preparation for Christianity's more complete revelation, instead of as a totally depraved system." 25 The fulfillment theorists are not content with merely replacing old cultural forms with new Christian ones. They are also concerned with

${ }^{20}$ Smith, “A Typology of Christian Responses to Chinese Ancestor Worship,” 629.

${ }^{21}$ Ibid., 641.

${ }^{22}$ Louis J. Luzbetak, The Church and Cultures: New Perspectives in Missiological Anthropology (Maryknoll, NY: Orbis Books, 1988), 67.

${ }^{23}$ Paul Hiebert, Anthropological Insights for Missionaries (Grand Rapids, MI: Baker Books, 1985), 185; Mary Yeo Carpenter, "Familism and Ancestor Veneration: A Look at Chinese Funeral Rites," Missiology: An International Review 24, no. 4 (October 1996): 504.

${ }^{24}$ Hiebert, Anthropological Insights for Missionaries, 185.

${ }^{25}$ Smith, “A Typology of Christian Responses to Chinese Ancestor Worship,” 638, 640. 
finding approaches to satisfy the meanings behind the traditional rites as a way of respecting the important motives that form the foundation of traditional practices. ${ }^{26}$ This type of sympathetic evangelism is also susceptible to syncretism.

The substitution paradigm seeks Christian functional substitutes to replace what it sees as valuable social and psychological functions of traditional rituals to satisfy the function of old religious practices and thus fill the gaps left by eliminating non-biblical practices. ${ }^{27}$ While the substitution model retains the theological exclusivism of the displacement model, it nevertheless acknowledges that an inconsiderate Christian approach to traditional religions builds up barriers that keep many people from fully responding to the gospel. Biblically appropriate functional substitutes provide enough cultural continuity along with the change to adequately convey Christian meanings and forms within the traditional context. They also afford the best means of meeting felt needs associated with rites of passage without creating cultural voids. ${ }^{28}$

This dissertation draws on principles of the substitution paradigm. Although this paradigm of mission may have some weaknesses, it appears to be the most credible of the four models. Using the critical contextualization approach, this paradigm emphasizes "the importance of formulating, presenting, and practicing the Christian faith in such a way that is relevant to the cultural context of the target group in terms of conceptualization, expression and application; yet maintaining theological coherence, biblical integrity, and

\footnotetext{
${ }^{26}$ Smith, "A Typology of Christian Responses to Chinese Ancestor Worship,” 639.

${ }^{27}$ Ibid., 635.

${ }^{28} \mathrm{Ibid} ., 635$.
} 
theoretical consistency." ${ }^{29}$ It is essential that the universal message of the Word of God, which transcends all cultures, be particularized in each ministry context. ${ }^{30}$

\section{Statement of the Problem}

African social structure puts considerable pressure on many converts to Christianity to take part in ATR rituals, which most of the time include unbiblical practices (e.g., sacrificing to the ancestors, divination, providing gifts to the deceased for their journey to the land of the ancestors) in order to be accepted as full members of their communities and tribes. Such situations can easily lead new converts to succumb to dual allegiance and syncretism as they continue to practice elements of ATR. The Seventh-day Adventist (SDA) Church in Burkina Faso is faced with the problem of understanding and resolving the syncretistic challenges faced by both new converts and established members in the Lobi context.

\section{Purpose Statement}

The purpose of this research is to do an ethnographic study of the Lobi funeral rites and then to propose a biblical and missiological framework for responding to the challenges they pose to Christian mission. This will help the SDA Church make true disciples and avoid syncretism and dual allegiance among its members.

\section{Research Questions}

Three main questions will guide this study:

\footnotetext{
${ }^{29}$ Enoch Wan, "Critiquing the Model of the Traditional Western Theology and Calling for SinoTheology," Chinese Around the World (November 1999): 13.

${ }^{30}$ Tennent, Invitation to World Missions, 334
} 
1. What are some of the cognitive, affective, and evaluative meanings attached to the Lobi funeral rites?

2. How does the Bible evaluate the issues related to Lobi funeral rites?

3. What approach to missions among the Lobi in regard to their funeral rites would best facilitate the development of biblical Christianity?

\section{Justification for the Research}

Mission always takes place in particular contexts in which religion, culture, and many other factors play significant roles in people's approach to what matters to them. ${ }^{31}$ A thorough understanding of a people group's cultural practices is therefore a prerequisite to any effective cross-cultural communication of the gospel to them. ${ }^{32}$

By investigating the cultural meanings associated with one of the most important rites of passage among the Lobi in Burkina Faso, evaluating them in the light of Scripture, and proposing a biblical and missiological framework for responding to the challenge they pose to Christian mission, this research has the potential to make a significant contribution towards effective ministry and mission.

\section{Conceptual Framework}

The conceptual framework of this study builds on the models developed by Paul Hiebert and Charles Kraft to address cross-cultural issues in mission as well as on the categories developed by Ronald L. Grimes, Catherine Bell, and Victor Turner to describe

\footnotetext{
${ }^{31}$ Sanou, "Motivating and Training the Laity," 42.
}

${ }^{32}$ Lloyd E. Kwast, "Understanding Culture," in Perspectives on the World Christian Movement, 4th ed., ed. Ralph D. Winter and Steven C. Hawthorne (Pasadena, CA: Institute of International Studies, 2009), 397. 
the structure, perspectives, and dimensions of rituals. This study of the impact of culture on religious practices will be based on:

1. An exegesis of the Lobi culture. Paul Hiebert asserts that there are three basic dimensions of culture: the cognitive, the affective, and the evaluative. ${ }^{33}$ Because Scripture needs to penetrate and transform every aspect of an individual's life, the Lobi funeral rites have been studied using these three dimensions of culture.

2. A ritual exegesis of the Lobi funeral rites. According to Ronald L. Grimes, the first prerequisite to understand a rite adequately is to fully describe that rite. He provides a set of six categories that help in mapping the field of ritual. (a) Ritual space: where does the ritual enactment occur? (b) Ritual objects: what, and how many objects are associated with the rite? What is done with those objects? (c) Ritual time: at what time of the day does the ritual occur? (d) Ritual sound and language: does the rite employ nonlinguistic sounds such as animal calls, shouting, or moaning? What moods are avoided? (e) Ritual identity: what ritual roles and offices are operative — elder, priest, diviner, healer? Who participates most fully? (f) Ritual action: what kinds of actions are performed as part of the rite? What are the central gestures? ${ }^{34}$ Grimes argues that "if we are to treat rites as seriously as we do ethics and theologies, we must work with full, evocative descriptions, not merely summaries of the values and beliefs implicit in them." 35 A detailed ritual exegesis of the Lobi funeral rites will help highlight their socio-cultural significance.

\footnotetext{
${ }^{33}$ Hiebert, Anthropological Insights for Missionaries, 30-34.

${ }^{34}$ Ronald L. Grimes, Beginnings in Ritual Studies, 3rd ed. (Waterloo, Ontario, Canada: Ritual Studies International, 2010), 19-32. See also Catherine Bell, Ritual Perspectives and Dimensions (New York: Oxford University Press, 1997), and Victor Turner, The Ritual Process: Structure and AntiStructure, 2nd ed. (New Brunswick, NJ: Aldine Transaction, 2008).

${ }^{35}$ Grimes, Beginnings in Ritual Studies, 19.
} 
3. A biblical exegesis of selected passages. This step is necessary to understand the biblical principles about funeral rites to give a biblical and theological response to the issues related to the Lobi funeral rites.

4. A biblical and missiological response to Lobi funeral rites. Although the Word of God is supreme over each culture, the books of the Bible have been revealed and written within specific cultures. Charles H. Kraft argues that "if the church is to be meaningful to receiving peoples, it needs to be [as] appropriate to their cultural lives as the early Church was to the lives of first century peoples." ${ }^{36}$ In other words, Jesus' religion is to be incarnated into every culture. The Willowbank Report also states that "God's personal self-disclosure in the Bible was given in terms of the hearers' own culture. ... The biblical writers made critical use of whatever cultural material that was available to them for the expression of their message." ${ }^{\prime 7}$ Because the "universal dimension of the gospel precludes any ethnocentrism or parochialism,"38 all genuine communication of the gospel in missions should seek to make the gospel concepts and ideas relevant to people within their own cultures. ${ }^{39}$ While firmly maintaining biblical integrity, the church in its mission must also be resourceful and flexible in adjusting its

\footnotetext{
${ }^{36}$ Charles H. Kraft, "Culture, Worldview and Contextualization," in Perspectives on the World Christian Movement: A Reader, 4th ed., ed. Ralph D. Winter and Steven C. Hawthorne (Pasadena, CA: Institute of International Studies, 2009), 402.

${ }^{37}$ The Lausanne Committee for World Evangelization, "The Willowbank Report," in Perspectives on the World Christian Movement: A Reader, 4th ed., ed. Ralph D. Winter and Steven C. Hawthorne (Pasadena, CA: Institute of International Studies, 2009), 508.

${ }^{38}$ Andreas J. Köstenberger, "The Challenge of a Systematized Biblical Theology of Mission: Missiological Insights from the Gospel of John," Missiology: An International Review 23, no. 4 (October 1995): 456.

${ }^{39}$ Hiebert, Anthropological Insights for Missionaries, 55.
} 
methods and procedures to the changing situations of the world in which it finds itself. The relevance of the Church in any context depends on its ability to effectively address the realities of the pressing socio-cultural problems encountered by its converts. ${ }^{40}$

Although all cultures are human and therefore corrupted by sin, we must nonetheless recognize that the gospel can still be comprehended and applied from within every culture. ${ }^{41}$ There is, however, the possibility of falling into syncretism in the process of gospel transmission/translation. Therefore, Paul Hiebert advocates for an ongoing critical contextualization. ${ }^{42}$

\section{Methodology}

Missiology is concerned with overcoming barriers to the full reception of the gospel. Many of those barriers are cultural. For that reason, ethnographic descriptions have been used to address the breadth of the cultural issues related to the Lobi funeral rites of passage. In the process, library research, interviews, and observation of public behavior at funerals have been conducted to provide a base for understanding the Lobi social, cultural, and religious contexts. As missiological thinking should flow from scriptural principles, selected biblical passages have been closely examined to give a biblical and theological response to the issues related to human condition after death and the traditional Lobi funeral rites.

\footnotetext{
${ }^{40}$ Nthamburi, "Making the Gospel Relevant Within the African Context and Culture," 162.

${ }^{41}$ Craig Ott, Stephen J. Strauss, and Timothy C. Tennent, Encountering Theology of Mission: Biblical Foundations, Historical Developments, and Contemporary Issues (Grand Rapids, MI: Baker Academic, 2010), 268.

${ }^{42}$ Hiebert, Anthropological Insights for Missionaries, 186-190.
} 
The process of data collection during my field research was based on observation of people's behavior at a funeral ceremony and on a purposeful sampling of 16 participants for interviews in order to have a personal understanding of the Lobi cultural and religious contexts. I interviewed three Lobi religious leaders, six Lobi Adventists who have taken part in funeral rites before becoming Adventists, two Lobi Adventists who continue to take part in funeral rites, four Lobi Adventists who are being pressured to participate in funeral rites, and a Lobi Catholic priest who has published on Lobi funeral rites. All the participants in my interviews were adults.

\section{Delimitation}

This study of the Lobi funeral rites is limited to current practices and does not probe deeply into their historical origin and how they may have evolved over the last few centuries.

\section{Limitations}

The following are the limitations to this project: (1) there is a scarcity of written resources dealing with funeral rites of passage as practiced by the Lobi in Burkina Faso; (2) Many Adventists who are known to participate in death-related rites declined my invitation for interviews; (3) The number of respondents (15) appears less than ideal; and (4) My non-Lobi origins give me a certain bias in my approach to this study.

\section{Dissertation Outline}

This dissertation is structured around six chapters. The first chapter sets the background of the study.

Chapter 2 discusses the religious, social, and cultural dimensions of the Lobi 
funeral rites. Since in the Lobi context every aspect of life revolves around religion, this chapter focuses on the impact of religious beliefs on everyday life in the Lobi context. Important Lobi rites of passage are discussed with an emphasis on funeral rites, which are believed to lead to a person's elevation to ancestorhood, and on the role ancestors are believed to play in the life of the community.

Chapter 3 examines death and funeral rites in the Bible with a special interest in the biblical view of life and death, the rituals and cultural practices surrounding death, and three forbidden death-related rituals in Scripture.

Chapter 4 reports on my field research. It also highlights five major biblical and missiological challenges that need to be addressed for effective ministry and mission among the Lobi.

Chapter 5 proposes a biblical and missiological framework for responding to the Lobi funeral rites. The principles of this framework could also apply to studying any group of people in order to ensure that the gospel presentation is both biblically coherent and culturally relevant, thus minimizing the risk of religious syncretism.

Chapter 6 summarizes the dissertation, draws conclusions, and makes recommendations for enhancing Seventh-day Adventist mission and ministry in crosscultural settings in general and among the Lobi in particular. 


\section{CHAPTER 2}

\section{RELIGIOUS AND SOCIO-CULTURAL ASPECTS \\ OF THE LOBI FUNERAL RITES}

\section{Introduction}

The focus of this chapter is to describe the religious, social, and cultural dimensions of Lobi funeral rites of passage. The description starts with the religious context because religion is a fundamental element of Lobi life and is at the center of every aspect of their social and cultural life. Everything undertaken by the Lobi is informed by their religious beliefs. ${ }^{1}$ Mbiti rightly remarks that "Africans are notoriously religious" to the point that "religion permeates into all departments of life so fully that it is not easy or possible always to isolate it."

As primarily a religious activity, funerals play a very important role among the Lobi as in the rest of traditional African contexts. ${ }^{3}$ The traditional Lobi society is

\footnotetext{
${ }^{1}$ Hervé Sansan Pooda, interview by author, Gaoua, Burkina Faso, May 12, 2014. Hervé Sansan Pooda is a Lobi Catholic priest based in Gaoua, Burkina Faso. He has done extensive work on the Lobi funeral rites of passage. I had a long interview with him during my field research.

${ }^{2}$ Mbiti, African Religions and Philosophy, 1.

${ }^{3}$ There are excellent sources dealing with similarities in funeral rites across many African societies. I use some of these sources on shared African beliefs and practices in my description of the Lobi funeral rites when I know from my experience of living among the Lobi and from my field research that the Lobi share these general characteristics. These general characteristics of funeral rites in traditional African contexts have also been cross-checked with the available primary sources dealing with the Lobi funeral rites.
} 
conservative in that it is their religious tradition that dictates the contours of all the other aspects of life. The societal structures are believed to have been revealed to their ancestors for whom they have great reverence and respect. Ancestors are believed to have a continuing influence on the living community. Following the footsteps of their ancestors is therefore perceived both as a privilege and a mandate. Society cannot fully understand itself unless its members continue to learn and act upon what has been transmitted to and by their ancestors. According to Hervé Sansan Pooda, among the Lobi funerals are so important that they always supersede other scheduled social activities. ${ }^{4}$ Funerals bring more people together in Lobi villages than any other social event. All other activities must be stopped in order to honor the dead. ${ }^{5}$ This makes relating to funerals a key aspect of effective mission.

\section{Socio-Cultural Context of the Lobi}

\section{Brief History and Geographic Location}

According to history the Lobi migrated in successive waves from northwest Ghana in search of fertile uncultivated land and settled in the southwestern part of Burkina Faso and the northern part of Côte d'Ivoire. Today this people group is found in

${ }^{4}$ Pooda, interview, May 12, 2014.

${ }^{5}$ Hervé Sansan Pooda, La Mort Comme Voyage Vers L'Au-delà chez les Lobi d'Afrique de l'Ouest: Une Lecture Africaine de la Bible en Jean 11:1-44 (Sarrebruck, Germany: Editons Universitaires Européennes, 2010), 7. In 2001 as Hervé Sansan Pooda and other priests were preparing to celebrate the midnight Christmas Mass, it was reported that someone died in the village. Because of that death, only very view of their parishioners showed up at the mass. Traditional religious practices have more importance to many Lobi converts to Christianity. This is an example of the very entrenched syncretism among some Christians (p. 8). 
Ghana, Burkina Faso, and Côte d'Ivoire. ${ }^{6}$ Hervé Sansan Pooda asserts that the details of Lobi history remain a mystery due to the fact that they do not recount historical events; historical preference is given to the memory of their rites. ${ }^{7}$ Some historians of the Lobi assert that their society took shape in the mid-nineteenth century when the djoro (or jòrò), a powerful socio-religious organization, was set up to ascribe the Lobi identity to their community members by means of initiation. ${ }^{8}$

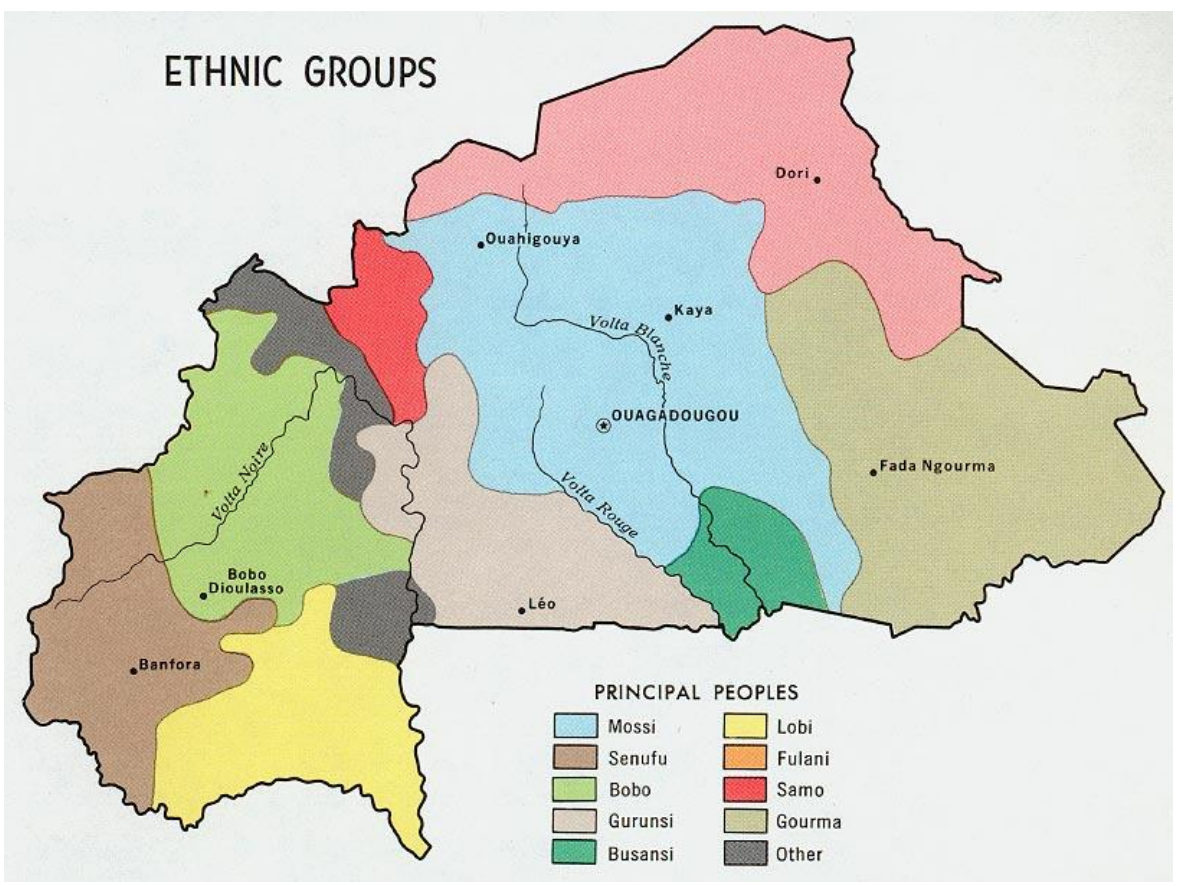

Figure 1. Major ethnic groups of Burkina Faso. Source: "Les communutés du Burkina Faso," accessed December 11, 2014, http://www.planete-burkina.com/ethnies_burkina _faso.php.

\footnotetext{
${ }^{6}$ Ama Mazama, "Lobi," Encyclopedia of African Religion, ed. Molefi Kete Asante and Ama Mazama (Los Angeles, CA: SAGE, 2009), 382. See also Jack Goody, Death, Property and the Ancestors: A Study of the Mortuary Customs of the Lodagaa of West Africa (Stanford, CA: Stanford University Press, 1962), 3-12, and Hervé Sansan Pooda, La Mort Comme Voyage Vers L'Au-delà chez les Lobi d'Afrique de l'Ouest: Une Lecture Africaine de la Bible en Jean 11:1-44 (Sarrebruck, Germany: Editons Universitaires Européennes, 2010), 79-84.
}

${ }^{7}$ Pooda, La Mort Comme Voyage Vers L'Au-delà, 80.

${ }^{8}$ Daniela Bognolo, Lobi (Milan: 5 Continents Press, 2007), 7-9 and Madeleine Père, Les Lobi: Tradition et Changement, Tome 1 (Laval, France: Editions Siloë, 1988), 230-256. 


\section{Social Organization}

There is no centralized political system among the Lobi. ${ }^{9}$ This very unique social characteristic of the Lobi means that they have no village or ethnic chiefs, in contrast to all other people groups in Burkina Faso. The major structural organizations are the village, the clan (patriclan or matriclan), and the nuclear family ${ }^{10}$ but the patriclan and matriclan remain the two major categories of social groupings. There are four matriclans called car and about one hundred patriclans or kuon. ${ }^{11}$ The patriclan refers to the paternal lineage and is said to have started with the jòrò initiation rites, that is, long after the matriclan. ${ }^{12}$ As such, it is only at the initiation ceremony that a Lobi really discovers his/her patriclan and its rules and regulations as well as its religious secrets. ${ }^{13}$ The matriclans provide the Lobi with their roots. The members of a matriclan are united by blood lines dating back to a common female ancestor. ${ }^{14}$ Positions of authority reside within the patriclans, however "the jurisdiction of any one of these extends only to a very limited number of persons." ${ }^{" 15}$ The only clearly visible role of direct authority is at the

${ }^{9}$ Jack Goody, Death, Property and the Ancestors: A Study of the Mortuary Customs of the Lodagaa of West Africa (Stanford, CA: Stanford University Press, 1962), 3.

${ }^{10}$ Pooda, La Mort Comme Voyage Vers L'Au-delà, 83.

${ }^{11}$ Cécile de Rouville, Organisation Sociale des Lobi: Une société Bilinéaire du Burkina Faso et de la Côte d'Ivoire (Paris: L'Harmattan, 1987),

${ }^{12}$ de Rouville, Organisation Sociale des Lobi, 175.

${ }^{13}$ Jan Ovesen, "Initiation: A Folk Model among the Lobi," in Personhood and Agency: The Experience of Self and Others in African Cultures, ed. Michael Jackson and Ivan Karp (Washington, DC: Smithsonian Institution Press, 1990), 151; Pooda, La Mort Comme Voyage Vers L'Au-delà, 85; de Rouville, Organisation Sociale des Lobi, 192.

\footnotetext{
${ }^{14}$ Pooda, La Mort Comme Voyage Vers L'Au-delà, 85.

${ }^{15}$ Goody, Death, Property and the Ancestors, 7.
} 
family level, between a father and his children.

In the absence of a centralized political system, the community is held together by religious values under the custody of the elders, priests, and especially the custodian of the Earth shrine (didar) who functions as the high priest for the whole village. ${ }^{16}$ The office of the didar is an influential religious office because the didar is the one who speaks for and represents the ancestors and mediates between them and the living. ${ }^{17}$ The ancestors guarantee social order, protection, and well-being in every aspect of life to all the inhabitants. The inhabitants of each village are thought to be further united by the fact that they drink the same water, eat from the same land, and have common taboos. ${ }^{18}$

\section{Community Life and Social Values}

The Lobi social structure places an important emphasis on communal life. Community centeredness is a highly cherished social value. Solidarity among group members is the first and most important Lobi social value. The Lobi are known to be united both in happiness and in misfortune. This high sense of solidarity obliges the whole group to avenge a group member who is attacked or killed by another group. ${ }^{19}$ Generally,

In Burkina Faso, communities are closely knit together by a web of relationships and other social structures that emphasize corporateness as against individualism. The community makes and produces the individual. The individual has no existence of his own apart from the community... . The culture knows no isolated individual. Man is

\footnotetext{
${ }^{16}$ de Rouville, Organisation Sociale des Lobi, 133, 238.

${ }^{17}$ Sanou, "Motivating and Training the Laity," 58.

${ }^{18} \mathrm{de}$ Rouville, Organisation Sociale des Lobi, 125.

${ }^{19}$ Pooda, La Mort Comme Voyage Vers L'Au-delà, 89.
} 
man because he belongs. He is part of a larger family, clan or a tribe. ${ }^{20}$

The Lobi are very conscious of shame and honor. The 'lobiduur or the ideal Lobi is another revered social value. The concept of 'lobiduur can be described as one who has courage, excellence, honor, and good social reputation. It pushes each person to put his/her honor, that of his/her immediate family, and that of his/her group above all other social norms. A person with a good sense of 'lobiduur takes good care of his/her family, avenges his relatives, and participates fully in the community's social and religious events. Failure to live up to that ideal brings shame not only on the individual, but also on his/her family and clan. ${ }^{21}$

\section{Status, Leadership, and Rites of Passage}

The traditional Lobi society is hierarchical in its structure just as its religious universe is hierarchical. The progression of life is divided into stages, and transitions are marked by well-defined rituals. ${ }^{22}$ Paul Hiebert, Daniel Shaw, and Tite Tiénou explain that "these 'life cycle rites' transform persons from one level of identity to another, and in so doing, give them a growing sense of worth and importance." ${ }^{23}$ Because there are no chieftaincy titles among the Lobi, status is mostly achieved through hard work and rites of passage. ${ }^{24}$ Rites of passage are part of the socially recognized means through which

${ }^{20}$ Sanou, "Motivating and Training the Laity," 56.

${ }^{21}$ Pooda, La Mort Comme Voyage Vers L'Au-delà, 90.

${ }^{22}$ See Catherine Bell, Ritual: Perspectives and Dimensions (New York: Oxford University Press, 1997), and Victor Turner, The Ritual Process: Structure and Anti-Structure (New Brunswick, NJ: Aldine Transaction, 2008).

${ }^{23}$ Paul G. Hiebert, R. Daniel Shaw, and Tite Tiénou, Understanding Folk Religion: A Christian Response to Popular Beliefs and Practices (Grand Rapids, MI: Baker Books, 1999), 98.

${ }^{24}$ Ovesen, "Initiation: A Folk Model among the Lobi," 161. 
individuals achieve status in their community ${ }^{25}$ because these rites mark the passage of an individual from one stage to another and from one role or societal position to another. Although birth is also a rite of passage, the three most important rites of passage that confer status on individuals among the Lobi are initiation, marriage, and funeral rites. These rites of passage are very important because of the social and cultural identity they provide to the participants. ${ }^{26}$ Apart from ascribing social status and leadership roles to its members through their participation in rites of passage, traditional African society also believes that societal harmony is not possible without them. ${ }^{27}$ As such, rites of passage take on significant implications for both the participants and their communities since they “help define and redefine the community's relationship to an individual and the individual's changing place in the community."28

\section{Introduction to Rites of Passage}

Catherine Bell defines rites of passage as "ceremonies that accompany and dramatize such major events as birth, coming-of-age initiations for boys and girls, marriage, and death. Sometimes called 'life-crisis' or 'life-cycle' rites, they culturally mark a person's transition from one stage of social life to another." 29 The content of rites of passage reveals societal values at their deepest level. Rites of passage hold the key to

\footnotetext{
1:527-529.

${ }^{25}$ Johnson Pemberton III, “Iconography,” Macmillan Compendium: World Religions (1998 ed.),

${ }^{26}$ Gailyn Van Rheenen, Communicating Christ in Animistic Contexts (Pasadena, CA: William Carey, 1991), 38.

${ }^{27}$ Osadolor Imasogie, "The Nature of Rites of Passage in African Traditional Religion," Ogbomoso Journal of Theology 7 (December 1992): 14.

${ }^{28}$ Wayne E. Oates, When Religion Gets Sick (Philadelphia, PA: Westminster Press, 1970), 81.

${ }^{29}$ Bell, Ritual, 94.
} 
understanding how people think and feel about what matters to them and therefore form the basis for interacting with their natural and social environments. ${ }^{30}$ The value of rites of passage is found in the fact that they publicly declare that the socio-cultural order of a society supersedes the natural biological order. In other words, "physical birth is one thing; being properly identified and accepted as a member of the social group is another. Likewise, the appearance of facial hair or menses does not make someone an adult; only the community confers that recognition, and it does it so in its own time." 31

The Lobi attach great importance to their rite of passage. In the following pages I discuss their birth, initiation, and marriage rites. Their funeral rites are then discussed under the heading "Lobi Funeral Rites."

\section{Birth Rites among the Lobi}

Birth is the first rite of passage every human being goes through. Among the Lobi, no celebration is usually held for an unborn child. Birth is followed by the seclusion of the mother and her child from all except close elderly women relatives. The seclusion lasts three days when the child is a boy and four days when the child is a girl. During this period of seclusion, the mother is thought to be unclean and also at the mercy of evil spiritual forces. To keep these malevolent forces away from her and the child, she must constantly hold a knife or a broom. To end the assigned period of isolation, the mother and her child are ritually bathed and their heads shaved. ${ }^{32}$ It is only then that the

\footnotetext{
${ }^{30}$ Turner, The Ritual Process, 6.

${ }^{31}$ Bell, Ritual, 94.

${ }^{32}$ Henri Labouret, Les Tribus du Rameau Lobi (Paris: Institut d'Ethnologie, 1931), 309.
} 
child is ceremoniously presented to the community and a name is given. ${ }^{33}$ Sacrifices are made to thank God and the ancestors for blessing the community with reproductive success. They are also asked to watch over the child. ${ }^{34}$ The name given to a child at birth is only temporary until he/she receives at initiation the name which confers on him/her the supra-identity of Lobi. Once that happens, the individual ceases to be called by his/her earlier name. ${ }^{35}$

\section{Initiation Rites among the Lobi}

The very first rite of passage that gives a recognized status to an individual in traditional Africa in general and among the Lobi in particular is that of initiation. The importance of this rite resides in the fact that it incorporates the young as full members in the society. Initiation brings the individual a step closer to ancestorhood. An uninitiated person cannot be ushered into the realm of the ancestors at death because he/she is not a full Lobi. ${ }^{36}$ The transformation of children into responsible adults is a major function of the initiation rites. ${ }^{37}$

\footnotetext{
${ }^{33}$ Names are given following the children's birth order from the same mother. Thus, in a polygamous family several children bear the same name. See Labouret, Les Tribus du Rameau Lobi, 312. For example, for boys, the first is named Sié, the second is Sansan, the third is Ollo, and the fourth is Bébé, etc. For girls the first is Yéri, the second is Mini, and the third is called Mèmè.

${ }^{34}$ de Rouville, Organisation Sociale des Lobi, 174, 180-181. See also Katherine Olukemi Bankole, "Birth," Encyclopedia of African Religion, ed. Molefi Kete Asante and Ama Mazama (Los Angeles, CA: SAGE, 2009), 124-125.

${ }^{35}$ Ovesen, "Initiation: A Folk Model among the Lobi," 164; Labouret, Les Tribus du Rameau Lobi, 314; de Rouville, Organisation Sociale des Lobi, 181.

${ }^{36}$ Ovesen, "Initiation: A Folk Model among the Lobi," 164.

${ }^{37}$ Hiebert et al., Understanding Folk Religion, 100.
} 
The Lobi initiation rite (dyoro or jòrò) is held once every seven years ${ }^{38}$ usually from November to January. ${ }^{39}$ Because the dyoro takes place every seven years, participants are of widely different age. One of the distinctive features of the djoro is that everything having to do with it "is surrounded by great secrecy. In principle, no nonLobi, and no Lobi who has not yet been initiated into the dyoro, is allowed to know anything about it." ${ }^{40}$ This major collective initiation rite confers on all the participants, "men and women, regardless of their origin, the supra-identity of 'Lobi.",41 Ovesen further notes that it is participation in the dyoro "that makes a Lobi a Lobi." 42 Because the dyoro is a collective initiation rite, it carries both social and religious connotations. ${ }^{43}$ Initiation rites are thus considered very important community values. By initiating its young people into adulthood, "a society not only socializes its young by outwardly moving them into new roles of social responsibility, but also transforms them inwardly by molding their moral and mental disposition towards the world." 44

Initiation rites are educational school settings for training young people in the

\footnotetext{
${ }^{38}$ Bognolo, Lobi, 8; de Rouville, Organisation Sociale des Lobi, 192.

${ }^{39}$ Labouret, Les Tribus du Rameau Lobi, 416.

${ }^{40}$ Ovesen, "Initiation: A Folk Model among the Lobi," 151.

${ }^{41}$ Bognolo, Lobi, 8 .

${ }^{42}$ Ovesen, "Initiation: A Folk Model among the Lobi," 164.

${ }^{43}$ Père, Les Lobi, 275.

${ }^{44}$ Benjamin C. Ray, African Religions: Symbol, Ritual, and Community (Englewood Cliffs, NJ:
} Prentice-Hall, 1976), 91. 
skills of living useful and productive lives in their communities. ${ }^{45}$ Initiates are educated in the responsibilities of adult life. ${ }^{46}$ The occasion usually marks the beginning of acquiring tribal knowledge and wisdom that is only available to those who have been initiated. It is a period of awakening to many things and a time to receive secret instructions. Among the Lobi, the introduction to the art of communal living happens when the group to be initiated withdraws from the community, usually for several weeks, to live alone in a specific place. ${ }^{47}$ The tribal "curriculum" carries so much weight that a person is not yet a full member of the community unless he/she has been initiated. All those who have been initiated together form a lifelong peer group. Since the underlying emphasis is on separation from childhood and incorporation into adulthood, no matter how old an individual is, so long as he/she is not initiated, he/she is still considered to be a child. ${ }^{48}$

The initiation into adulthood implies that "for the well-being of a society certain facts of life must be mastered through the observance and participation in some rituals before one can enter into adulthood. Therefore, the young adults must be ritually initiated into adulthood, upon whom dwells the responsibility for social and spiritual well-being of the community." 49 But beyond the mere necessity of mastering the important concepts of

\footnotetext{
${ }^{45}$ Denis M'Passou, "The Continuing Tension between Christianity and Rites of Passage in Swaziland," in Rites of Passage in Contemporary Africa: Interaction between Christian and African Traditional Religions, ed. James L. Cox (Cardiff, UK: Cardiff Academic Press, 1998), 15.

${ }^{46}$ Hiebert et al., Understanding Folk Religion, 100.

${ }^{47}$ Ovesen, "Initiation: A Folk Model among the Lobi," 154.

${ }^{48}$ de Rouville, Organisation Sociale des Lobi, 192; Mbiti, African Religions and Philosophy, 119.

${ }^{49}$ Ademola S. Ishola, "The Sociological Significance of the Traditional African Concept of Rites of Passage," Ogbomoso Journal of Theology 7 (December 1992): 27.
} 
life, initiation rites also provide for the development of social norms as part of the societal mores that are considered essential to the continued existence and the ongoing solidarity and corporateness of the whole community. ${ }^{50}$ Initiates "are transformed from passive to active members of the society, and entrusted with preserving social traditions." 51

The initiation rite of passage may be seen as following a threefold ritual pattern consisting of rites of separation, transition, and reincorporation, of which the middle phase of transition is considered the most important. ${ }^{52}$ "In this phase people are metaphysically and sociologically remade into 'new' beings with new social roles.",53 This transitional period is the time for "cultural indoctrination when cultural values and worldview perspectives are especially explicit." ${ }^{, 54}$ This phase of the initiation rite aims at ensuring proper departure out of the prior status and proper identification with and recognition in the new status. ${ }^{55}$ To be spiritually transformed, the Lobi initiates must first be taken out of their usual profane world and ushered into the sacred world of initiation. ${ }^{56}$ According to Mbiti, the withdrawal of youth from society during African initiation rites is 28.

${ }^{50}$ Ishola, "The Sociological Significance of the Traditional African Concept of Rites of Passage,"

${ }^{51}$ Hiebert et al., Understanding Folk Religion, 101.

${ }^{52}$ Ovesen, "Initiation: A Folk Model among the Lobi," 154.

${ }^{53}$ Ray, African Religions, 91.

${ }^{54}$ Van Rheenen, Communicating Christ in Animistic Contexts, 37.

${ }^{55}$ James L. Cox, "Ritual, Rites of Passage and the Interaction between Christian and Traditional Religions," in Rites of Passage in Contemporary Africa: Interaction between Christian and African Traditional Religions (Cardiff, UK: Cardiff Academic Press, 1998), xi.

${ }^{56}$ Ovesen, "Initiation: A Folk Model among the Lobi," 154. 
interpreted as

a symbolic experience of the process of dying, living in the spirit world and being reborn (resurrected). The rebirth, that is the act of rejoining their families, emphasizes and dramatizes that the young people are now new, they have new personalities, they have lost their childhood, and in some societies they even receive completely new names. ${ }^{57}$

Another important feature of African initiation rites is that they provide the initiates a ritual process for reviewing and repeating what their ancestors said, did, and experienced as members of the same community. Initiation rites are therefore also concerned with showing proper respect to the ancestors who must be revered as the custodians of the tribal ethics. It is understood that without enlisting the ancestors' active involvement in community affairs, cultural unity would only be an illusion. ${ }^{58}$ Therefore, every family in the tribe ensures that its members, at the age for initiation, take an active part in the rituals because of the belief that

a society is in equilibrium when its customs are maintained, its goals attained and the spirit powers given regular adequate recognition. Members of society are expected to live and act in such a way as to promote society's well-being; to do otherwise is to court disaster not only for the actor but also for the society as a whole. Any act that detracts from the soundness of society is looked upon with disfavor and society takes remedial measures to reverse the evil consequences set in motion. ${ }^{59}$

Because initiation rites are seen as "a process of culture transmission and community survival," ${ }^{60}$ an individual's failure to undergo the prescribed initiation rites brings shame on his/her family and community as a whole and thus amounts to self-

${ }^{57}$ Mbiti, African Religions and Philosophy, 118.

${ }^{58}$ Imasogie, "The Nature of Rites of Passage in African Traditional Religion," 16.

${ }^{59}$ Kwesi A. Dickson, Theology in Africa (Maryknoll, NY: Orbis Books, 1984), 62.

${ }^{60}$ Mwalimu J. Shujaa, "Initiation," Encyclopedia of African Religion, ed. Molefi Kete Asante and Ama Mazama (Los Angeles, CA: SAGE, 2009), 342. 
excommunication from the entire life of the community. Any misfortune in the families or clans will be interpreted as the ancestors' unhappiness with this "moral disorder in relationships" ${ }^{\prime 61}$ that resulted in the "disequilibrium of societal peace and harmony."62 In the traditional mind-set, such individuals are considered social isolates or deviants because "to be cut off from relationships with one's ancestors is to cease to be a whole person."

\section{Marriage Rites among the Lobi}

Marriage is a universal rite of transition and is a means for a society to publicly announce "the changes in the status of the bride and groom so that the people can make appropriate adjustments in their behavior toward the couple." 64 Among the Lobi, marriage is more than just a social matter or an affair between a man and a woman. It is a binding contract that always involves at least two families and all their subunits (extended family members). Marriage is also a deeply religious act because it involves the ancestors. ${ }^{65}$ Upon marriage, the husband is invested with household priestly

\footnotetext{
${ }^{61}$ Laurenti Magesa, African Religion: The Moral Traditions of Abundant Life (Maryknoll, NY: Orbis Books, 1997), 81. 28.

${ }^{62}$ Ishola, "The Sociological Significance of the Traditional African Concept of Rites of Passage,"

${ }^{63}$ Jack Partain, "Christians and Their Ancestors: A Dilemma of African Theology," The Christian Century 103, no. 36 (November 26, 1986): 1067.

${ }^{64}$ Hiebert et al., Understanding Folk Religion, 101.

${ }^{65}$ Ama Mazama, "Marriage," Encyclopedia of African Religion, ed. Molefi Kete Asante and Ama Mazama (Los Angeles, CA: SAGE, 2009), 409.
} 
functions. ${ }^{66}$ He thus gains respect and he is listened to in his village. ${ }^{67}$ Since marriage is intimately linked with procreation, and also for the reason that parenthood is one of many criteria for a Lobi to become an ancestor at death, getting married is of utmost importance in the traditional Lobi society. ${ }^{68}$ A very common cause of divorce is infertility on the part of one of the partners. ${ }^{69}$ When a man dies, his brother usually marries the widow(s) and thus spares her/them and her/their children a life of misery.

\section{Conceptual Background of Lobi Funeral Rites}

The Lobi religious universe is pyramidal: God is at the pinnacle, followed by spirits and ancestors, and then humans at the base. ${ }^{70}$

\section{The Concept of God}

God is not an unfamiliar being to African peoples. The knowledge of God is expressed and passed on from one generation to another through means easy to remember such as proverbs, songs, people's names, myths, stories, and religious ceremonies and festivals. These means are so readily available that they predispose people, right from childhood, to the knowledge of the reality of God's existence. There is no set time when

${ }^{66}$ Labouret, Les Tribus du Rameau Lobi, 280.

${ }^{67}$ Pooda, La Mort Comme Voyage Vers L'Au-delà, 90.

${ }^{68}$ Mahmoud Malik Saako, Samuel N. Nkumbaan, Christopher Boatbil Sormiteyema, and Azerikatoa D. Ayoung, "Birifoh Belief System: Perspectives from Birifoh-Sila Yiri, Upper West Region, Ghana," Research on Humanities and Social Sciences 4, no. 3 (2014): 86.

${ }^{69}$ Mazama, "Marriage," 411. Women are usually the first to be blamed for a couple's inability to have children. People stop blaming them only if after divorce they remarry and have children. It is only then that the blame is directed to the former husband.

${ }^{70}$ Ovesen, "Initiation: A Folk Model among the Lobi," 149. 
people are taught about God. ${ }^{71}$ Although some African notions about God resemble some biblical and Semitic ideas about God, ${ }^{72}$ their dissemination in African societies is not believed to be the result of their contact with Judaism, Christianity, or Islam. ${ }^{73}$ An important concept of God in traditional Africa is that he is perceived to be transcendent but made immanent through the mediation of spirits and ancestors. His transcendence makes him outside and beyond his creation. His immanence through the mediation of spirits and ancestors makes him involved in his creation, so that nothing in the visible or the invisible worlds is outside of him or his reach. Thus, although in general God is placed on a transcendental plane, making it seem as if he is distant, isolated, and inaccessible, he is nevertheless involved in humans' daily affairs through closely associated spiritual beings and natural phenomena. ${ }^{74}$

Tangba or Thãgbá is the word for God in Lobiri (the language spoken by the Lobi). Although the same word can also mean rain, the two meanings are always kept separate. To the Lobi, Tangba is the Creator of all forms of life, both visible and invisible. ${ }^{75}$ Although Tangba is omnipotent, he is neither worshiped ${ }^{76}$ nor does he directly intervene in the affairs of human beings. ${ }^{77}$ Because Tangba is the originator of

${ }^{71}$ Mbiti, African Religions and Philosophy, 29.

${ }^{72}$ Such attributes include God's omnipotence, omniscience, and omnipresence. See John S. Mbiti, Concepts of God in Africa (London: SPCK, 1970), 3-18.

${ }^{73}$ Mbiti, African Religions and Philosophy, 29, 30.

${ }^{74}$ Ibid., 29, 36.

${ }^{75}$ Ovesen, "Initiation: A Folk Model among the Lobi," 149.

${ }^{76}$ Ibid., 149.

${ }^{77}$ Labouret, Les Tribus du Rameau Lobi, 398. 
everything that exists, both visible and invisible, no one has the right to make an image of him or try to confine him to space and time. Only some manifestations or powers that are thought to emanate directly from Tangba (e.g., the thunder) can be represented and worshiped. ${ }^{78}$ It is widely believed that God has left the running of the world in the hands of the lesser gods. Sacrifices are made to the gods and ancestors who act as intermediaries between Tangba and humans. But any sacrifice offered to them is offered ultimately to Tangba. These beings are only the medium for sending sacrifices to God. By worshiping these intermediary spirit beings, it is strongly believed that it is to Tangba worshippers address their prayers. ${ }^{79}$

\section{Spirits}

The African religious ethos cannot be completely understood without considering its concepts of the spirit world in addition to its concepts of God. This spirit world is thought to be populated by masses of spirits. ${ }^{80}$ There are broadly two categories of spirits. The first category of spirits is believed to have been created by God as a race by themselves. The other category of spirits is believed to be the ancestors. ${ }^{81}$ Because the spirits are unpredictable (they could be good but could also be bad depending on their

\footnotetext{
${ }^{78}$ Père, Les Lobi, 206.

${ }^{79}$ Pooda, La Mort Comme Voyage Vers L'Au-delà, 85, 87.

${ }^{80}$ Ovesen, "Initiation: A Folk Model among the Lobi," 150.

${ }^{81}$ Mbiti, African Religions and Philosophy, 77.
} 
humor), acknowledging and rightly worshiping them is a way in which equilibrium can be maintained in the universe. ${ }^{82}$

Among the Lobi, the first category of spirits - those created by God as a race by themselves - is called the tila. Worship among the Lobi is mainly centered on the tila (spirits with human characteristics). ${ }^{83}$ The tila are represented by wooden, metal, or ceramic statuettes. According to the Lobi, these statuettes and the shrines in which they are sometime found represent the relationships between the spiritual and physical worlds. ${ }^{84}$ The Lobi believe in a multitude of tila. A small sample is as follows: tila of the river, of the cave, of the mountain, of the market, of the forest, etc. The most popular tila among the Lobi are those of the thunder (thãgba), of the earth (dithil), of the matriclan (wathil), and of the patriclan (thilkhaa). ${ }^{85}$

\section{Ancestors}

Kontin (plur. Kontina) is the term for ancestor(s) in Lobiri. It means "a great one" or "an elder" and carries "connotations of importance, old age, and primacy." 86 The Lobi practice a cult of their ancestors for the mediation role they play between the tila, Tangba, and the living. "Highly respected elders are usually buried in the middle of the family compound or in front of the family house rather than in the cemetery. This is to

\footnotetext{
${ }^{82}$ Johannes Triebel, "Living Together with the Ancestors: Ancestor Veneration in Africa as a Challenge for Missiology," Missiology: An International Review 30, no. 2 (April 2002): 187-189. See also Bolaji Idowu, African Traditional Religion: A Definition (London, UK: SCM Press, 1973), 193.

${ }^{83}$ Ovesen, "Initiation: A Folk Model among the Lobi," 150.

${ }^{84}$ Saako et al., "Birifoh Belief System,” 86.

${ }^{85}$ Pooda, La Mort Comme Voyage Vers L'Au-delà, 87; Ovesen, “Initiation: A Folk Model among the Lobi," 150.

${ }^{86}$ Ovesen, "Initiation: A Folk Model among the Lobi," 150.
} 
keep them close to the family who are constantly being watched over by the dead elder or ancestor." ${ }^{87}$ The ancestors are regularly honored with animal sacrifices and libations. In the typical traditional Lobi context, it is a taboo for responsible people to eat or drink without first serving the ancestors, which is done by placing or pouring part of the meal and the drink on the ground for the ancestors. Such actions show their belief in the superiority of their ancestors in relation to human beings. ${ }^{88}$

In order to understand the importance of funeral rites in traditional Lobi societies, one must first grasp the central traditional belief in ancestors and their influence over every sphere of communal life. To the Lobi, a human being is made up of a soul (sie) covered with skin or a body (yanggan). At death the body decays but the soul escapes and is believed to continue its existence wandering as a ghost until it is released by the final ceremony of the second funeral rite to go and join the ancestors. ${ }^{89}$ In this traditional understanding of things, life does not end with death but continues in another realm.

Mbiti asserts that "without exception, African peoples [traditionally] believe that death does not annihilate life and that the departed continue to exist in the hereafter." 90 As such, the concepts of life and death are not mutually exclusive concepts. "Through death, what is this-worldly spills over into what is other-worldly." ${ }^{91}$ The living and their

\footnotetext{
${ }^{87}$ Sidonia Alenuma, "The Dagaare-Speaking Communities of West Africa," Journal of Dagaare Studies 2 (2002): 10-11.

${ }^{88}$ Pooda, La Mort Comme Voyage Vers L'Au-delà, 88.

${ }^{89}$ Goody, Death, Property and the Ancestors, 364, 371.

${ }^{90}$ Mbiti, Concepts of God in Africa, 264.

${ }^{91}$ Augustine Kututera Abasi, "Lua-Lia, The 'Fresh Funeral': Founding a House for the Deceased Among the Kasena of North-East Ghana," Africa 65, no. 3 (1995): 448.
} 
dead relatives (the ancestors) live in a symbiotic relationship because the community is a continuum consisting of the living and the dead. ${ }^{92}$ The relation between the living and the dead stands out as one of the most fundamental features of African traditional religious life. The use of the word "ancestors" may generally refer to the dead progenitors of a family, clan, or tribe, but in traditional religious understanding it mostly refers to dead members of a family, clan, or tribe to whom the living members of the group continue to pay regular cultic homage.

Ancestors play a very important role in family matters. The Lobi hold their ancestors in high respect because of the belief that those who reach ancestorhood are never dead but "continue to live in the other world of spirits and serve as media between their relatives, the spirits and gods," and are thought to possess the "ability to protect, guide, and offer showers of blessing to the living." 93 Ancestors are thus thought to watch over the lineage and to be involved with household matters.

Among the Lobi not every death automatically results in funeral rituals leading to one's incorporation into the company of his/her lineage ancestors. ${ }^{94}$ Several criteria exist among the Lobi to determine the eligibility of a deceased person to move to ancestorhood. ${ }^{95}$ A person attains ancestorhood generally on the basis of a long life and moral superiority. ${ }^{96}$ Among the Lobi, as in many other African traditional contexts,

\footnotetext{
${ }^{92}$ Amanze, "Christianity and Ancestors Veneration in Botswana,” 46.

${ }^{93}$ Alenuma, "The Dagaare-Speaking Communities of West Africa," 9.

${ }^{94}$ Goody, Death, Property and the Ancestors, 52.

${ }^{95}$ Ibid., 223.

${ }^{96}$ Amanze, "Christianity and Ancestors Veneration in Botswana," 43.
} 
ancestorhood is synonymous with moral superiority and exemplary leadership. To be elevated to the rank of ancestor, a person must possess certain qualities such as long life, parenthood, physical integrity, morality, self-control, and proper death. ${ }^{97}$ The followings deaths are considered bad deaths: death by drowning, lightning, suicide, or death in the course of initiation. No funeral rites are held for such people. ${ }^{98}$ A sin that warrants a denial of funeral rites for a deceased is the killing of a fellow patriclansman. There is no provision for such a sin to be expiated. "In life, such a man is excluded from the congregation of the ancestor cult and ritually prohibited from consuming any of the sacrificial offerings; in death, he is totally and finally rejected from the clan." 99

In this traditional way of thinking, the relationship to the ancestors is fundamental to the sense of selfhood and society. ${ }^{100}$ The widespread idea that the ancestors play a very important role in the life of their surviving communities is rooted in the belief that the human personality survives the death and decay of the body. 101 "Regardless of their mode of existence it is commonly believed that the ancestors still live, though invisible, and that they are certainly present in the life of the individual and the community. . . They see everything, hear everything, are interested in the affairs of human beings, and wish,

${ }^{97}$ Saako et al., "Birifoh Belief System," 86, 88.

${ }^{98}$ Pooda, interview. May 12, 2014.

${ }^{99}$ Goody, Death, Property and the Ancestors, 224.

${ }^{100}$ Partain, “Christians and Their Ancestors: A Dilemma of African Theology,” 1069.

${ }^{101}$ Edwin W. Smith, "The Idea of God among South African Tribes," in African Ideas of God: A Symposium, ed. E. W. Smith (London: Edinburgh House Press, 1950), 86. 
above everything else, to be remembered." ${ }^{\prime 102}$ Following are three key roles played by the ancestors.

First, the ancestors are believed to be the guarantors of life and well-being and as such, they are incorporated in the community network of relationships. According to Johannes Triebel, the phrase "living together with the ancestors," which also includes their veneration, summarizes the traditional African cultural and religious identity."103 Triebel further argues that in the traditional African mind-set,

The ancestors are here, they influence our lives, and we depend on them. Our wellbeing and possible misfortune are related to them. Fear and hope are like two poles that characterize the dependence on the ancestors. Living together with the ancestors means fear and hope at the same time. ... Everyone who neglects the relationship to his or her ancestors endangers his or her life, indeed the life of the whole community. The wrath of the ancestors can cause misfortune, illness, hunger, and death. It is therefore necessary to ensure their favor and benevolence towards the living and thus to preserve the stream of life. ${ }^{104}$

The notion of fear and hope is based on the belief that at death people carry along their personalities to the next life. Consequently, "if it is an angry father who dies, one expects him to be a rather angry ancestor. If family members had a short-tempered elder as their head, they become particularly careful in making certain that after he is dead he is not annoyed, knowing that he always was a man who became annoyed very easily." 105 However, the most significant element in the ancestors' interaction with the world of the living is that they are also "irrevocably committed to the well-being of their lineage and

\footnotetext{
${ }^{102}$ Amanze, "Christianity and Ancestors Veneration in Botswana," 44.

${ }^{103}$ Triebel, "Living Together with the Ancestors," 187.

${ }^{104}$ Ibid., 187, 189.

${ }^{105}$ Amanze, "Christianity and Ancestors Veneration in Botswana," 46.
} 
its continuance." ${ }^{106}$ In other words, while on one hand the ancestors can cause misfortune, on the other hand they can grant fortune, well-being, life, and good living. ${ }^{107}$ Therefore, it is quite wrong to conclude that ancestor veneration is based only on fear and the desire to escape suffering and harm.

Second, the ancestors are the representatives of law, order, and ethical values in the community. "They are the guardians of family affairs, traditions, ethics and activities. Offense in these matters is ultimately an offence against the forebearers who, in that capacity, act as the invisible police of the families and the communities." ${ }^{108}$ Punishment is the ultimate result of every offense against the ancestors and their commands. Therefore, misfortune, illness, and death in the community are often interpreted as the sign of the ancestors' anger because of an individual or family's misconduct. Any time the ancestors' authority is questioned, they in turn question people's lives. To repair an incident with the ancestors (e.g., to heal sickness, to prevent further cases of misfortune) and re-establish lost harmony, offerings are made as reconciliation to appease them. Hence, it is "only by respecting the ancestors and giving them their offerings [either to have good fortune or to repair misfortune], only by respecting the laws and orders set by them will one have a successful life." 109

Third, the ancestors act as intermediaries between people and God because of

\footnotetext{
${ }^{106}$ Aylward Shorter, "Conflicting Attitudes to Ancestor Veneration in Africa," African Ecclesial Review 11, no. 1 (January 1969): 29.

${ }^{107}$ Idowu, African Traditional Religion, 193.

${ }^{108}$ Mbiti, African Religions and Philosophy, 82.

${ }^{109}$ Triebel, "Living Together with the Ancestors," 189.
} 
their close association with the living and their proximity to God. It is believed that "just as an African chief is approached through an intermediary, so prayer may go to God through the ancestral spirits." ${ }^{\prime 10}$ Messages to God are entrusted to ancestors who know God in a way not possible for any human being. Ancestors are able to occupy this intermediate position because of their ability to "“speak' a bilingual language of human beings whom they recently 'left' through physical death, and of the spirits to whom they are now joined, or of God to whom they are now nearer than when they were physical men."111

With such a high position associated with ancestorhood, it is considered a curse in traditional Lobi context for someone to be denied funeral rites. Such a person is considered lost for his/her soul will be an eternal wanderer without any possibility of joining the ancestors and having peace. This is a major reason why funeral rites carry such important socio-cultural significance among the Lobi.

\section{Lobi Funeral Rites of Passage ${ }^{112}$}

Because of the general belief among the Lobi that there is life after death, funeral rites are elaborate ceremonial occasions as they are considered to be the indispensable means by which human beings pass from the land of the living to that of the ancestors. ${ }^{113}$

${ }^{110}$ Edward Geoffrey Parrinder, Religion in Africa (Baltimore, MD: Penguin Books, 1969), 69.

${ }^{111}$ Mbiti, Concepts of God in Africa, 230.

${ }^{112}$ This section draws heavily from interviews (especially with Hervé Sansan Pooda) and observation during my field research.

${ }^{113}$ Alenuma, "The Dagaare-Speaking Communities of West Africa," 9. 
There are three main stages in the Lobi funeral rites: mourning the dead, finding the cause of death, and the funeral rites themselves.

\section{Mourning the Dead}

In the traditional African context in general, death is not merely a family affair. It is a matter of public concern both far and near. Among the Lobi whenever a person is thought to be on the verge of death, the senior male in the compound sends boys or young men to personally inform all his/her close relatives. This is a solemn call for them to attend the dying person during his/her last moments. In a person's last moments, he/she must be sitting up and if at all possible be in the arms of a close kinswoman. ${ }^{114}$

Lobi funeral ceremonies are moments of intense demonstration of emotions. When a person dies, the ancestors are quickly consulted to know if the deceased person's funerals should be done in the prescribed way. A baby chicken is sacrificed to them. If the sacrificed baby chicken falls on its back, it symbolizes the ancestors' agreement for people to proceed with the funeral rites. If it falls forward, it means the ancestors are not in favor of the person having funeral rites. In the case of the ancestors' agreement, women start wailing and lamenting very loudly to alert neighbors and the village as a whole about the death that has just occurred. ${ }^{115}$ Because funerals are communal events, men use gun shots to alert surrounding villages. Messengers are sent far and near to inform other relatives and friends. The xylophone is played to spread the news and also to indicate, depending on the particular tune, whether the deceased is a man or a woman. All

\footnotetext{
${ }^{114}$ Goody, Death, Property and the Ancestors, 49.

${ }^{115}$ Labouret, Les Tribus du Rameau Lobi, 319.
} 
those who hear the funeral xylophone notes, be it faintly, have an obligation to attend the funeral. Failure to do so may be taken as an indication of possible involvement in the death. ${ }^{116}$

\section{Finding the Cause of Death}

In African societies there is a belief that there once was a very close relationship between God and humans; a relationship compared to that of a loving father and his children. God either lived among humans or visited them very frequently. ${ }^{117}$ Several myths are told about how the happy relation between God and his creatures came to an end. ${ }^{118}$ According to the Lobi oral tradition, Tangba "withdrew from the world because he was getting increasingly annoyed with the quasi constant fighting among men over women."119 Several unfortunate consequences such as "the loss of immortality, resurrection, rejuvenation, and free food, in addition to the coming of death and suffering" ${ }^{120}$ resulted from the broken relationship between God and humans. Death first occurred and continues to occur as one of the consequences of this separation.

Nevertheless, God is not believed to be behind every death. Every human death is thought to also have other unnatural/supernatural causes. ${ }^{121}$ In the traditional context,

\footnotetext{
${ }^{116}$ Goody, Death, Property and the Ancestors, 51, 86.

${ }^{117}$ Mbiti, Concepts of God in Africa, 171.

${ }^{118}$ Mbiti, African Religions and Philosophy, 94-97.

${ }^{119}$ Mazama, "Lobi,” 382.

${ }^{120}$ Mbiti, Concepts of God in Africa, 177.

${ }^{121}$ Mbiti, African Religions and Philosophy, 151.
} 
every death thus has a hidden cause that must be known before the deceased is buried. ${ }^{122}$ For example when someone dies of a snake bite, the snake is perceived not as the cause of the death but rather as an intermediary agent. ${ }^{123}$ While mourning goes on, many attempts are made to determine with some degree of certainty the cause of death. This may be done by recourse to divination, ${ }^{124}$ or the dead person is carried by two men on their heads and he/she is asked to lead the carriers to the person responsible for his/her death. They believe that the carriers are moved by an irresistible force/energy/power and obey all the deceased person's promptings. There is a specific code through which people know if the deceased person says yes or no to the questions being asked. ${ }^{125}$

To the Lobi death is never natural nor accidental: "Why has it not happened yesterday? Why not in two days? Why has it happened today?" 126 Death always occurs through an intermediary agent. Witches, sorcerers, ancestors, or other supernatural beings are the primary causes of death. However, the attribution of a death to ancestors and other supernatural beings does not always mean that they themselves directly caused the death of the person. It means that because of an offense done against them they have simply withdrawn their protection from the person so that he/she became an easy prey for witches, workers of curses, and sorcerers. As such, the ancestors and supernatural beings

\footnotetext{
${ }^{122}$ Labouret, Les Tribus du Rameau Lobi, 319-320.

${ }^{123}$ Goody, Death, Property and the Ancestors, 208.

${ }^{124}$ Ibid., 210.

${ }^{125}$ Labouret, Les Tribus du Rameau Lobi, 320.

${ }^{126}$ Pooda, interview, May 12, 2014.
} 
are the cause of death by withdrawing their protection over people and thus permitting either mystical or non-mystical aggression. ${ }^{127}$

There are four possible causes of death. The first cause of death is largely attributed to magic, sorcery, and witchcraft. This means that someone is almost always behind the cause of someone else's death. Second, a powerful curse placed on someone is believed to be able to bring about death. As a result of these beliefs about the main causes of death, most deaths are perceived to be cases of homicide. The third possible cause of death is attributed to ancestors and other spirits. Ancestors and spirits are believed to cause death whenever they are offended. An improper burial ceremony or a failure to follow prescribed rites may be reasons for the ancestors' wrath. Death by snakebite, accident, or by any disease is likely to be attributed to these three first causes. What has to be established is the person/ancestor that was connected with the intermediary agent, snake, accident, or disease. ${ }^{128}$

In theory the fourth and least likely cause of death occurring among the Lobi is attributed to God. Death as an act of God usually is considered when the deceased person is a child who dies before being weaned ${ }^{129}$ or one who has lived a very long life, in which

${ }^{127}$ Goody, Death, Property and the Ancestors, 209, 210.

${ }^{128}$ Ibid., 208.

${ }^{129} \mathrm{Ibid}$. Such a child "is not regarded as a human at all, but as a being of the wild that has come to trouble the parents with this pretense of mortality." 
case it is considered a natural death. ${ }^{130}$ Nevertheless in practice, the attribution of a death to God is very uncommon.

\section{The Central Funeral Rites}

Funeral rites seem to vividly express the deepest concepts people have about life. In traditional African thinking, "dead people are not dead at all. Death is only a transitional state to a spiritual life free from material hindrances." ${ }^{\prime 31}$ Death is spoken of as a departure, a setting out on a journey, a transition to ancestorhood. Nevertheless, whenever it occurs, "the soul of the deceased must undergo a series of spiritual adjustments if he or she is to find a secure place in the afterlife and continue to remain in contact with the family left behind." 132 Funeral rites are performed to reduce the effect of the sudden loss as well as a means of facilitating the process by which the deceased joins the community of the ancestors. A traditional funeral is believed not only to help the deceased reach their "fathers" (i.e., enter the ancestral world) but also to "have a tomorrow" (i.e., a continuation of life in the lineage). ${ }^{133}$ This is the community's expressed desire for kinship continuity and solidarity even in death. The community's survival is crucial and rests on the strict observance of proper burial and funeral rites to help the deceased make a good and successful journey to the ancestral world to join those

\footnotetext{
${ }^{130}$ Mbiti, African Religions and Philosophy, 151. Goody, Death, Property and the Ancestors, 208209 points out that "the death of a man whose sons have themselves begotten sons is thought of in a different way. Such a person has reached the end of his allotted span. He is too weak to arouse the anger of shrine, ancestor, or mortal."

${ }^{131}$ Amanze, "Christianity and Ancestors Veneration in Botswana," 44.

${ }^{132}$ Benjamin C. Ray, African Religions: Symbol, Ritual, and Community (Englewood Cliffs, NJ: Prentice-Hall, 1976), 140.

${ }^{133}$ Abasi, "Lua-Lia, The 'Fresh Funeral'," 448, 450, 451.
} 
who ensure life and well-being, and who become intermediaries to the living.

There are two stages in Lobi funeral rites: the first funeral rite (bii) and the second funeral rite (bobuur).

\section{The First Funeral Rite}

Once it is has been determined through divination that the deceased person deserves a funeral rite, the first funeral rite automatically starts. This gives room to even more laments because the deceased who is allowed to have a funeral was a good person. The deceased is first placed in a room surrounded by family treasures. The funeral rituals officially start when the "owner of the grief"134 throws twenty cowries on the ceremonial xylophone. Other mourners and well-wishers also throw their cowries at the feet of the deceased. ${ }^{135}$ Cowries are provisions for the deceased's expenses in his/her journey to the land of the dead, especially for the ferryman to ensure the crossing of the river which is believed to separate the land of the living from that of the dead. ${ }^{136}$ Family members further interrogate the deceased in an attempt to find the cause of his/her death. The deceased is then ceremonially bathed by ritual specialists and dressed in his/her most beautiful garments and taken to a public place where more people may have easy access to express their honor to him/her. ${ }^{137}$ The deceased is always seated facing the east, the

134، The closest patrikinsman of a man, the father, brother, or son, or the husband of a married woman is known as the senior mourner (kutuosob, "the owner of the grief") and is ultimately responsible for seeing that the [funeral] ceremony is properly performed" (see Goody, Death, Property and the Ancestors, 49).

\footnotetext{
${ }^{135}$ Pooda, interview, May 12, 2014.

${ }^{136}$ Goody, Death, Property and the Ancestors, 371.

${ }^{137}$ Labouret, Les Tribus du Rameau Lobi, 319, 321.
} 
direction to the land of the dead, surrounded by the wealth of his/her family. More gifts are provided for the journey to the land of the dead. Other gifts and messages are entrusted to him/her for the ancestors. ${ }^{138}$

Funeral ceremonies continue throughout the night, and similarly to the Dagaarespeaking communities described here, usually

involve musicians, mourners and the assembled villagers and guests from neighboring villages. The music group usually consists of xylophonists, drummers and singers. The singers improvise, recreate and reproduce through their songs the history of the family up to the death that resulted in the separation. The theme of the songs is a combination of the deeds and sorrows of the family. The best singer is one who can stir the maximum level of grief in the chief-mourners (the closest relatives of the diseased) by his choice of words. The effect of the words of the singers is echoed and amplified by the tunes of the xylophones and the sounds of the drums, moving the community to grieve freely. Wailing, screaming, groaning, running, jumping, dancing and singing are all acceptable ways of expressing grief. Shedding of tears is highly recommended and admired. The chief-mourners are expected to shed a lot of tears and behave in a way that stirs sympathizers to share the grief to the fullest by shedding as many tears as possible. ${ }^{139}$

The funeral rituals continue for one, two, or even three days. During this time a new grave is dug or a family tomb is reopened after a baby chicken has been sacrificed to ask the permission of the earth to bury the deceased. The decision of when to bury the dead person is always the prerogative of the chief mourner. When that is done, intense wailing and gun shots are performed as a sign of their farewell to the deceased. After the burial of the dead, a stick (gboo) representing him/her is placed in the house. This reminds family members that although the dead person is not physically visible, he/she is still part of the family. Another night of funeral vigil is often held after the burial. Gifts

${ }^{138}$ Pooda, La Mort Comme Voyage Vers L'Au-delà, 106.

${ }^{139}$ Alenuma, "The Dagaare-Speaking Communities of West Africa," 9-10. The Dagara, Birifor, and Lobi communities share many common religious concepts. I have personally observed such scenes during my field research. 
continue to be received. But this time they serve to pay for the expenses of the xylophonists, the drummers, and the gravediggers. ${ }^{140}$

To mark the end of the first funeral rite, the close relatives of the deceased are shaved as a further sign of bereavement but also to show that they honor the dead relative. The widow/widower and orphans start another period of bereavement. All of them are whitewashed because it is assumed that any association with death is a threat to the whole community. As such, those connected with the deceased (surviving spouse(s) and orphans) have to be cleansed of the defiling effects of their contact with him or her. The whiteness of the clay is seen as counteracting any death-related uncleanliness. Sexual intercourse and any close relationship between husband and wife are viewed as the sharing of the dirt of each other's bodies.

Whitewashing is said to free a surviving partner and orphans from any defilement received from the deceased. Unless the rite of whitewashing is performed it is believed that the dirt of the deceased partner will kill the surviving partner if he/she becomes involved in sexual intercourse with another partner. Whitewashing must be done to clean the dirt of the dead partner in order to enable the surviving spouse to have sexual intercourse with any other partner without risking death. ${ }^{141}$ Orphans whitewash their foreheads and wear strings of cowries over their shoulders. ${ }^{142}$ Although both widow(s) and widower are whitewashed, there is inequality between them regarding the length of

\footnotetext{
${ }^{140}$ Pooda, La Mort Comme Voyage Vers L'Au-delà, 107.

${ }^{141}$ Goody, Death, Property and the Ancestors, 183-193.

${ }^{142}$ Ibid., 101.
} 
this cleansing ritual. A widower does not undergo prohibition for as long as a widow does for two main reasons: (1) society does not expect a man to remain celibate for a long period especially if he has other wives and (2) a woman's funeral rite is concluded in a much shorter time than that of a man. ${ }^{143}$ Widows are particularly considered ceremonially unclean. They remain mostly secluded for the whole length of time between the first and the second funeral rites. They are not permitted to shower. For widows, whitewashing is both a means of purification and of preventing the dead husband from coming back and attempting to have sexual intercourse with them. ${ }^{144}$

Before the second phase of funeral rites, a lengthy course of action is undertaken to resolve all potential problems likely to hinder the journey of the deceased to the land of the dead. Diviners are invited and consulted in the compound of the deceased to reveal all the prescriptions to be observed. The time between the first and the second funeral rites can be two weeks to one whole year. ${ }^{145}$

\section{The Second Funeral Rite}

When all the hindrances to the journey of the deceased to the land of the ancestors have been ritually removed, the second funeral rite (bobuur) can begin. This phase may last between one to four days, or more, depending on the social status of the deceased. On the first day of the second funeral rite it is not uncommon to still hear some lamentations and wailing. But this quickly gives way to rejoicing on the second day. People rejoice

\footnotetext{
${ }^{143}$ Goody, Death, Property and the Ancestors, 194.

${ }^{144}$ Pooda, interview, May 12, 2014.

${ }^{145}$ Ibid.
} 
because they will soon have another mediator between them and other supernatural beings and God. A number of animals are sacrificed to send the deceased on his/her journey. The members of the community do their best to convince the older ancestors to welcome this new one in their midst. Once these sacrifices are made, the taboo that quarantined the widower, but more especially the widow(s) and orphans is lifted and thus they are fully reintegrated into the community. ${ }^{146}$ The second funeral rite ends with the carving of the shrine of the new ancestor which is added to that of the previous ancestors and the sharing of his/her property among his/her relatives. Among the Lobi,

The process of transmission, which begins at death, is a gradual one, for the dead man retains many of his rights until the final ceremony has been performed. As a ghost (nyããkpiin), he continues to hold some of the exclusive rights he held in life; it is only when he becomes an ancestor spirit (kpiin) and takes up permanent residence in the Land of the Dead that these rights can be taken over by the heir. Even then the dead man retains certain of his former interests, and he is still the social father of any children born to his widows who have been taken in leviratic marriage... . The whole system of sacrifice to one's forebears is linked, by the LoDagaa themselves, to the perpetual claims upon property. ${ }^{147}$

\section{Conclusion}

Full membership and fulfillment in the Lobi context, as it is in many other traditional African contexts, come to individuals as they participate in family and

${ }^{146}$ Pooda, La Mort Comme Voyage Vers L'Au-delà, 108-109.

${ }^{147}$ Goody, Death, Property and the Ancestors, 328. Among the Lobi, women also have right to inheritance. For example, if the deceased person is a woman, her cooking utensils and cloths are shared by her uterine (full) sisters and daughters. But any wealth accumulated in form of cowries, money, and livestock goes to her uterine (full) brothers and sons. In the case of a deceased man, the direct inheritors are usually his full brothers and sons. In traditionally Lobi thought, capital can only be accumulated by men; however, the male inheritors are expected to use this wealth for the benefit of their sisters and also for that of the deceased woman's husband (pp. 328-357). 
community relationships (beliefs, ceremonies, rituals, and festivals). ${ }^{148}$ Society knows no separation between social and religious life. In the traditional mind-set,

To be human is to belong to the whole community, and to do so involves participating in the beliefs, ceremonies, rituals and festivals of the community. ... A person cannot detach himself from the religion of his group, for to do so is to be severed from his roots, his foundation, his context of security, his kinships and the entire group of those who make him aware of his own existence. To be without one of these corporate elements of life is to be out of the whole picture. ${ }^{149}$

In many instances, an individual's failure to participate in some cultural practices amounts to self-excommunication from the entire life of the community. Because the social penalty for refusing to participate in some community rituals could be stiff, many people, out of fear of spirits and the penalty for not participating in important rites of passage prefer to follow the traditional customs. ${ }^{150}$

To the traditional Lobi mind-set it seems evident that life is meaningless without participation in the prescribed rites of passage. This is so because it is participation in such rites that gives a Lobi the Lobi identity. ${ }^{151}$ However, in spite of having the Lobi identity, if one cannot be joined to his/her ancestors at death, his/her whole achievement in this life amounts to nothing because he/she will forever be separated from his/her people. This belief is better captured as follows:

The world of the deceased whose memory is honoured through generations contrasts with the world of those who will never enjoy the rank of ancestor, some because the proper funeral rites were not performed, others because they died an unnatural death (for example by drowning or snake bite) and are therefore considered to be punished 2005), 127.

${ }^{148}$ Christopher Partridge, Introduction to World Religions (Minneapolis, MN: Fortress Press,

\footnotetext{
${ }^{149}$ Mbiti, African Religions and Philosophy, 2.

${ }^{150}$ Charles H. Kraft, Worldview for Christian Witness (Pasadena, CA: William Carey, 2008), 33.

${ }^{151}$ Bognolo, Lobi, 8; Ovesen, "Initiation: A Folk Model among the Lobi," 164.
} 
by the ancestors. Lastly, the ancestralisation process may not have been properly carried out. The spirits of this category of dead are forced to wander. ${ }^{152}$

Each family and clan member must therefore be involved in securing the future of the rest of the family and clan members; and this means properly contributing for their well-being both in this life and the hereafter. ${ }^{153}$

This chapter has reviewed the religious and socio-cultural significance of the Lobi funeral rites. The focus of the next chapter will be on death-related practices in Scripture.

${ }^{152}$ Bognolo, Lobi, 11.

${ }^{153}$ Ibid., 10. 


\section{CHAPTER 3}

\section{DEATH AND FUNERAL RITES OF PASSAGE IN THE BIBLE}

\section{Introduction}

Ritual theorists are in agreement that "the circumstances around a rite's performance are crucial to determining the rite's effect and significance."1 This chapter is a study of practices surrounding death in the Bible. It will consider cultural contexts and explore the biblical view of life and death, ritual practices surrounding death, and three forbidden death-related practices in Scripture. It should be remembered that all scholars approach these issues with their presuppositions on life and the human form of existence after death. After analyzing various scholars' views on each of these points, I conclude each section with my perspective as a Seventh-day Adventist.

\section{Cultural Contexts of the Bible ${ }^{2}$}

In ancient Israel, religious and social identity was closely tied. ${ }^{3}$ Jewish people found their identity in the fact that they belonged both to God and to one another. This

${ }^{1}$ Richard E. DeMaris, The New Testament in Its Ritual World (New York: Routledge, 2008), 12.

${ }^{2}$ In this discussion, I am well aware that there is significant cultural variation between Genesis and Revelation as well as commonalities.

${ }^{3}$ Kent L. Sparks, "Religion, Identity and Origins of Ancient Israel," Religion Compass 1, no. 6 (2007): 587. 
was also true in the Jewish cultural milieu at the time of the New Testament. ${ }^{4}$ Because of the communal nature of funeral rites of passage in traditional societies, this section will focus on the cultural values peoples in the Bible placed on the concept of community in order to better understand their relational concepts and how these might have influenced their view about death and its related rites. ${ }^{5}$

\section{Cultural Values of Community in the Old Testament}

The cultural context of the Ancient Near East (ANE) served as the incubator of biblical peoples' thought and literature ${ }^{6}$ Core values of the ANE culture were based on a "shame and honor" paradigm. In coherence with their communal structure, they assumed that individuals should have proper esteem and value not only in their own eyes, but also in the eyes of their community. ${ }^{7}$ This was expressed in several ways, but mainly through a group-centric identity, a corporate solidarity, and interdependent collaboration. ${ }^{8}$

The ANE culture emphasized the corporate nature of human existence and experience. ANE peoples never thought of valuing the individual separate from the

${ }^{4}$ Luke Timothy Johnson, The Writings of the New Testament: An Interpretation, rev. ed. (Minneapolis, MN: Fortress Press, 1999); David A. DeSilva, Honor, Patronage, Kinship \& Purity: Unlocking New Testament Culture (Downers Grove, IL: InterVarsity Press, 2000).

${ }^{5}$ Other factors that shaped funeral rites in the Old and New Testaments are discussed under "Biblical view of Life and Death" and "Rituals and Cultural Practices Surrounding Death in Scripture."

${ }^{6}$ Henry Jackson Flanders, Robert Wilson Crapps, and David Anthony Smith, People of the Covenant: An Introduction to the Hebrew Bible (New York: Oxford University Press, 1996), 50.

${ }^{7}$ John Goldingay, Old Testament Theology: Israel's Faith (Downers Grove, IL: InterVarsity Press, 2006), 530 .

${ }^{8}$ John Pilch, Introducing the Cultural Context of the Old Testament (Mahwah, NJ: Paulist Press, 1991), 49, 97, 98. 
community. ${ }^{9}$ Individuals belonged to their groups and their doings reflected those groups. ${ }^{10}$ This understanding was likely what led Haman's hatred of Mordecai to be projected towards Mordecai's people (Esth 3:5-6). Individuals were viewed as important to the extent that they were participants in the larger group of which they were a member. In such community-centeredness, people had a strong sense of their relationship to others because they were bound together by strong kinship ties. Life was not perceived as something to be shaped according to the needs of each individual. Individuals were only what they were as links in families, deriving their lives from the family, sharing it with the family, and leaving it to be continued in posterity. ${ }^{11}$

The importance of kinship is widely expressed in biblical literature. " $\mathrm{X}$ the son of Y" lies as a thread throughout the Old Testament. The use of surnames to identify an individual's link to families is foreign to the Old Testament. The Old Testament way of identifying individuals allowed their family connections to be established in a more comprehensive fashion (e.g., "Mordecai the son of Jair, the son of Shimei, the son of Kish, a Benjamite" Esth 2:5). ${ }^{12}$ People looked at themselves as part of a family, a clan, a tribe, and then a nation. It was of great importance to know who one's relatives were. In the periodic absence of a centrally-organized system to enforce law and order and to punish wrongdoers, "a person's safety was a function of the group to which he or she belonged, and in times of war it was the duty of those who were related to each other to

${ }^{9}$ Goldingay, Old Testament Theology: Israel's Faith, 528.

${ }^{10}$ John Bright, A History of Israel, 3rd ed. (London: Westminster, 1981), 93.

${ }^{11}$ Flanders et al., People of the Covenant, 143-144.

${ }^{12}$ John Rogerson and Philip Davies, The Old Testament World (Englewood Cliffs, NJ: PrenticeHall, 1989), 45. 
stand together."13 People lived with a deep sense of solidarity between individuals and their social group, in which the group had obligations to protect individuals from harm (Gen 35), injustice, and poverty (Lev 25:14-31, 35-43, 47-55).

In the ANE context, societal structures were believed to have been revealed to their ancestors for whom they had great reverence and respect, for they were thought to have continuing influence on the living community. ${ }^{14}$ Apart from that, they also believed that evil spirits were associated with human suffering. "To the ancient mind such sicknesses as the plague or pneumonia or liver ailments came on without any external physical cause such as an animal bite or a wound. They were explained by accusing evil spirits of creating the illness, or even by suggesting that God himself sent it as a punishment (Ps 39:10-11)."15 These beliefs also influenced the Israelites ${ }^{16}$ although they believed that ultimately the power over life, sickness, and death lays in the hands of God. ${ }^{17}$ The corporateness of the society included the living, the ancestors, evil spirits, and God. God's revelation to Israel in the ANE cultural context points to the important fact that "God demonstrates his respect and appreciation for human culture by working through it rather than above or outside it." 18

\footnotetext{
${ }^{13}$ Rogerson and Davies, The Old Testament World, 46.

${ }^{14}$ Flanders et al., People of the Covenant, 165, 166. 1984), 249.

${ }^{15}$ Lawrence Boadt, Reading the Old Testament: An Introduction (Mahwah, NJ: Paulist Press,

${ }^{16}$ In Lev 16 Azalel is described as a desert demon to whom the Israelites' sins were sent yearly on the Day of Atonement.

${ }^{17}$ Boadt, Reading the Old Testament, 249.

${ }^{18}$ Ibid., 159.
} 


\section{Cultural Values of Community in the Early Church}

The cultural background of the Early Church was a combination of Hellenistic civilization, Roman rule, and Jewish faith and culture. ${ }^{19}$

The Greek conquest of Palestine left a permanent mark on Jewish life. ${ }^{20}$ In expanding his empire, Alexander the Great intended more than a mere military conquest. Because he considered the Greek way of life to be best for all, he desired to create a Hellenized world by using several tools: (1) he brought with him poets, philosophers, and historians, (2) he encouraged his soldiers to intermarry with native women so as to create one race, (3) he made Greek the universal language, and (4) he actively encouraged religious syncretism whereby local deities were identified and then merged with the gods of the Greek pantheon. ${ }^{21}$ These Hellenistic influences gradually eroded the traditional Jewish culture of the Old Testament era.

Rome was very preoccupied with political power which it achieved either by violence or by extending the right of citizenship to members of military colonies, former soldiers, and local personages. ${ }^{22}$ It had a very hierarchical social structure from the family to the state level. In the family, the father had absolute authority over the material, financial, and religious affairs of the entire household, and also determined whom his children married. Children were expected to obey and honor their parents as one would honor the gods, and as such they continued to be obligated to them even after they moved

\footnotetext{
${ }^{19}$ Johnson, The Writings of the New Testament: An Interpretation, 21.

${ }^{20}$ Gary M. Bruce, Lynn H. Cohick, and Gene L. Green, The New Testament in Antiquity: A Survey of the New Testament Within its Cultural Contexts (Grand Rapids, MI: Zondervan, 2009), 26.

${ }^{21}$ Johnson, The Writings of the New Testament, 24.

${ }^{22}$ Ibid., 26.
} 
out of the family home. Harmony, not equality, was perceived as the highest goal in family life and society. To achieve harmony, individuals were expected to stay in their respective places in society. ${ }^{23}$

In this context, personhood continued to be connected to group values. Honor and dishonor were foundational social values. Their focus on shame and honor meant that "they were particularly oriented toward the approval and disapproval of others. This orientation influenced individuals to strive to embody the qualities and to perform the behaviors that the group held to be honorable and to avoid those acts that brought reproach and caused a person's estimation in the eyes of others to drop." ${ }^{24}$

The multicultural environment of the first century was quite challenging in that each group defined what was honorable or dishonorable according to its own distinctive set of values and beliefs. While these values sometimes overlapped, they also frequently clashed. The same behavior that one group held up and rewarded as honorable could be censured and viewed as an insult or disgraceful by another group, and vice versa. ${ }^{25}$ This was a disturbing contradiction for a Jew living outside of Judea:

If he lives by the Torah, he will be honored and affirmed as a valuable member of the community by his Jewish peers, but he will also be regarded with contempt and even find his honor openly assaulted by the majority of the Greco-Roman population. ... . If he desires the approval and affirmation of the members of the Greco-Roman culture (and the opportunity for advancement, influence and wealth that networking in that direction can bring), he may well abandon his strict allegiance to Jewish values. This was the course chosen by many Jews during the Hellenistic period. Most Jews, however, chose to remain faithful to their ancestral law and customs, and to preserve their culture and its values. To do so, they had to develop strategies for

${ }^{23}$ Bruce, Cohick, and Green, The New Testament in Antiquity, 90, 91, 345.

${ }^{24}$ David A. DeSilva, Honor, Patronage, Kinship \& Purity: Unlocking New Testament Culture (Downers Grove, IL: InterVarsity Press, 2000), 35.

${ }^{25}$ Ibid., 37. 
keeping themselves and their fellow Jews sensitive to Jewish definitions of the honorable and, at the same time, insulated from non-Jewish verdicts concerning honor and dishonor. ${ }^{26}$

This combination of different cultural mind-sets under one political rule shaped the matrix in which the Christian church was formed. Judaism provided the roots of Christianity although it came to regard the Christian faith as a pernicious heresy; Hellenism provided the intellectual soil in which Christianity grew although it considered its beliefs as philosophical nonsense; and Roman imperialism provided the protection that opened the possibility for its growth although it regarded it as an impractical weakness. ${ }^{27}$

Because of its Old Testament roots, the Early Church continued to emphasize kinship as a core value. But in this new community, kinship was no longer defined in terms of blood lines and ethnicity but rather in terms of shared faith and fellowship with God. The church was an environment of inclusion, acceptance, and open unity without discrimination on the basis of race, gender, or social status (Gal 3:28). Membership was open to all on the basis of professing faith in Christ as Savior and the public demonstration of complete allegiance to Christ through water baptism (Acts 2:37, 38). The Early Church expressed its values of corporate solidarity and kinship through the use of the body of Christ and family motifs to describe the interdependence between its members, and to convey the close bond that enabled them to treat each other as family members (Rom 12; 1 Cor 12; Eph 4; Gal 6:10; Eph 2:19; 1 Tim 3:15; 1 Pet 4:17). This new understanding of family kinship was no longer based merely on blood relationships

\footnotetext{
${ }^{26}$ DeSilva, Honor, Patronage, Kinship \& Purity, 39.

${ }^{27}$ Merrill C. Tenney, Exploring New Testament Culture: A Handbook of New Testament Times (Iowa Falls, IA: Word Bible Publishers, 2000), 67, 68.
} 
but more importantly on what might be called common character. ${ }^{28}$ Their concern was not power but the development of a lasting sense of interdependence and corporate solidarity among believers. This interdependence suggested that each member of the body had a unique role to play, and yet was dependent upon all other members. ${ }^{29}$

\section{Biblical View of Life and Death}

The Nature of Humans and the State of the Dead in the Bible

Before considering death and the state of the dead in Scripture, it is important to reflect briefly on what Scripture says about the nature of human beings. The creation story gives an account of the origin of life on earth. Two key texts are considered: Gen 1:26, 27 and Gen 2:7.

At creation, humanity was given the special status of being created in God's image:

Let us make mankind in our image, in our likeness, so that they may rule over the fish in the sea and the birds in the sky, over the livestock and all the wild animals, and over all the creatures that move along the ground. God created mankind in his own image, in the image of God he created them; male and female he created them. (Gen 1:26, 27, emphasis added)

The same concept is reiterated in Gen 5:1 and Gen 9:6. Genesis 5:1 simply states that "when God created mankind, he made them in the likeness of God" (emphasis added). Genesis 9:6 gives the very first clear implication for humanity being created in God's image. It states that it is because humanity is created in the image of God that human beings should not shed the blood of one another: "Whoever sheds human

\footnotetext{
${ }^{28}$ John Driver, Images of the Church in Mission (Scottsdale, PA: Herald Press, 1997), 142.

${ }^{29}$ Robert Banks, Paul's Idea of Community (Exeter, UK: Paternoster Press, 1980), 64.
} 
blood, by humans shall their blood be shed; for in the image of God has God made mankind" (emphasis added).

The image and likeness of God in humans has been the subject of many interpretations among scholars. Is image and likeness the same or are they referring to two different things? Is it physical, mental, or spiritual? Although this is not the focus of this dissertation, I concur with the view that "bearing God's image does not imply so much resembling God [physically] as representing Him. Man is God's collaborator (Gen 2:4-6, 15) and lieutenant (Pss 8:3-8; 115:6). ${ }^{\prime 30}$ The likeness of God in humans refers to "the representational functions of humans" which include "everything that enables humankind to rule over their sphere as God rules in His." ${ }^{31}$ The creation in the image and likeness of God sets humanity apart from other creatures, because only humanity (man and woman) has been granted this special status. Although no clear clues are given as to the features of the likeness of God, God's image in human beings and the dominion that was given them over other creatures (Gen 1:26) probably have to do with humanity's relationship both to other creatures and to God the Creator. In other words, people were created as relational beings. ${ }^{32}$ Also, because the Bible further says that God is spirit (John 4:24), it seems safer to see the image of God in humans in terms of their spiritual

\footnotetext{
${ }^{30}$ Aecio E. Cairus, "The Doctrine of Man," in Handbook of Seventh-day Adventist Theology, ed. Raoul Dederen (Hagerstown, MD: Review and Herald, 2000), 208.

${ }^{31}$ Ibid., 208.

${ }^{32}$ Moshe Reiss, "Adam: Created in the Image and Likeness of God," Jewish Bible Quarterly 39, no. 3 (July-September 2011): 184.
} 
nature. ${ }^{33}$ For Reiss, the image and likeness of God in humans are located in "some spiritual quality or faculty of the human person." ${ }^{34}$ In a nutshell, the creation of humans in the image of God, the highest conceivable status, affirms their dignity and worth. ${ }^{35}$ Our true identity is first and foremost found in the fact that we are created in God's image.

Genesis 2:7 gives the two basic components of every human being, namely a physical body and the breath of life which is immaterial: "The Lord God formed a man from the dust of the ground and breathed into his nostrils the breath of life, and the man became a living being." Scholars have also debated whether at death the body and spirit have an independent existence. Two main groups have emerged out of these debates.

Scholars such as H. David Lewis, Wayne Grudem, Gary R. Habermas, and James P. Moreland believe in the immortality of the soul on the basis of texts such as: "The dust returns to the ground it came from, and the spirit returns to God who gave it" (Eccl 12:7), "Do not be afraid of those who kill the body but cannot kill the soul. Rather, be afraid of the One who can destroy both soul and body in hell" (Matt 10:28), and the parable of the rich man and Lazarus (Luke 16:19-31). For them, between death and the resurrection, believers are in some kind of conscious state of intermediary existence. Lewis states that "throughout the centuries Christians have believed that each human person consists in a soul and body; that the soul survived the death of the body; and that its future life will be

\footnotetext{
33“"In Our Image" [Gen 1:26], Seventh-day Adventist Bible Commentary (SDABC), rev. ed., ed. Francis D. Nichol (Washington, DC: Review \& Herald, 1976-1980), 1:216.

${ }^{34}$ Reiss, “Adam: Created in the image and Likeness of God," 185.

${ }^{35}$ Ibid., 181.
} 
immortal." ${ }^{36}$ Wayne Grudem unpacks the nature of the immortal soul by defining death as "the temporary cessation of bodily life and a separation of the soul from the body.

Once a believer has died, though his or her physical body remains on the earth and is buried, at the moment of death the soul (or spirit) of that believer goes immediately into the presence of God with rejoicing" ${ }^{37}$ (emphasis added). Gary R. Habermas and James P. Moreland push this concept a step further by stating that in the intermediary state "the person enjoys conscious fellowship with God while waiting for a reunion with a new, resurrected body" ${ }^{38}$ (emphasis added).

For other scholars such as Joel Green and Edward Fudge, the body and the spirit cease to exist until the resurrection of the dead. Green states that

death must be understood not only in biological terms, as merely the cessation of one's body, but as the conclusion of embodied life, the severance of all relationships, and the fading of personal narrative. It means that, at death, the person really dies; from the perspective of our humanity and sans divine intervention, there is no part of us, no aspect of our personhood, that survives death. ${ }^{39}$

Although Eccl 12:7 says that at death the spirit (ruach) returns to God, in not one of the 379 instances of its use throughout the OT does ruach denote an intelligent entity capable of existence apart from a physical body, so far as man is concerned, and it must therefore be clear that such a concept is without basis as the teachings of the Scriptures themselves are concerned (see Gen. 2:7; 35:18; Num. 5:14; Eccl. 3:19-21; cf. on Num. 5:2; 9:6). That which here returns to God is simply

${ }^{36}$ H. David Lewis, Christian Theism (Edinburgh, Scotland: Clark, 1984), 125.

${ }^{37}$ Wayne Grudem, Systematic Theology: An Introduction to Biblical Doctrine (Grand Rapids, MI: Zondervan, 1994), 816.

${ }^{38}$ Gary R. Habermas and James P. Moreland, Beyond Death: Exploring the Evidence for Immortality (Wheaton, IL: Good News Publishers, 1998), 222.

${ }^{39}$ Joel B. Green, Body, Soul, and Human Life: The Nature of Humanity in the Bible (Grand Rapids: Baker Academic, 2008), 179. 
the life principle imparted by God to both man and beast (see on Eccl. 3: 19-21, where ruach is translated "breath"). ${ }^{40}$

For Edward Fudge, a human being is an indivisible whole. The soul and the spirit are not parts into which a human may be divided. The soul refers to the living human individual; in other words, human beings do not have souls, they are souls. The spirit is a constant reminder that humans have their source in God. ${ }^{41} \mathrm{He}$ further asserts that the consistent witness of the Old Testament is that when a person dies, it is the entirety of their soul that dies (Ezek 18:20). ${ }^{42}$

Scholars who say that no part of humans survives death argue that it was only when God breathed the breath of life into the inanimate body of Adam that it became a living being/soul (Gen 2:7) ${ }^{43}$ This is the point of view from which this dissertation is written. There is a difference between "breath of life," ruach, and "soul," nephesh, in Gen 2:7. The soul "denotes man as a living being after the breath of life entered into a physical body formed from the elements of the earth." 44 This is supported by the fact that the account of Gen 2:7 says that "man became a living soul. Nothing in the Creation account indicates that man received a soul—-some kind of separate entity that, at Creation

40"The Spirit" [Eccl 12:7], Seventh-day Adventist Bible Commentary (SDABC), 3:1104.

${ }^{41}$ Edward William Fudge, The Fire That Consumes: A Biblical and Historical Study of the Doctrine of Final Punishment, 3rd ed. (Eugene, OR: Cascade Books, 2011), 27.

${ }^{42}$ Ibid.

43“A Living Soul” [Gen 2:7], Seventh-day Adventist Bible Commentary (SDABC), 1:223.

${ }^{44}$ General Conference of Seventh-day Adventists, Seventh-day Adventist Believe: A Biblical Exposition of 27 Fundamental Doctrines (Washington, DC: Ministerial Association, 1998), 82. 
was united with the human body"45 (emphasis in the original). Also, humans were only given conditional immortality at creation, as attested to by Gen 2:15-17: "The LORD God took the man and put him in the Garden of Eden to work it and take care of it. And the LORD God commanded the man, 'You are free to eat from any tree in the garden; but you must not eat from the tree of the knowledge of good and evil, for when you eat from it you will certainly die"" (emphasis added). Adam and Eve's conditional immortality was changed to mortality when they disobeyed God and ate of the forbidden fruit (Gen 3). Death is simply the reversal of the process of creation. At death, the breath of life is withdrawn from the living being/soul, ${ }^{46}$ and "when that happens, the person dies. He or she ceases to exist. The "soul' is no more because the living person is no more." ${ }^{47}$ Other Bible passages also highlight the fact that the dead are in an unconscious, nonexistent state (Eccl 9:5, 6), a state of unconscious sleep (John 11:11-13), and the next thing they will be conscious of will be when Christ returns and raises them either to eternal life (1 Thess 4:13-17) or to eternal damnation (Matt 25:46).

\section{The Gathering to One's Ancestors/People}

Several passages in the Bible make mention of people being gathered to their ancestors at death (Gen 15:15; 25:8, 17; 35:29; 49:29-50:10; Gen 50:24-24). What did it mean for the Israelites to be gathered to their ancestors when they died? Scholars have diverging views as to what this phrase means.

\footnotetext{
${ }^{45}$ General Conference of Seventh-day Adventists, Seventh-day Adventist Believe, 81-82.

46“"A Living Soul” [Gen 2:7], SDABC, 1:223.

${ }^{47}$ Bryan W. Ball, “The Immortality of the Soul: Could Christianity Survive without It?" Ministry
} Magazine 83, no. 5 (May 2011): 15. 
For Philippe King and Lawrence Stager, "the biblical expression 'to sleep with' and 'to be gathered to one's fathers' refer to secondary burials within the family tomb," 48 that is, the deceased were temporarily placed in a grave until complete decomposition and the skeletal remains were then collected and added to those of relatives who died before. King and Stager base their argument on Huldah's prophecy to King Josiah, "I will gather you to your ancestors, and you will be buried in peace" ( $2 \mathrm{Kgs} 22: 20)$. Their emphasis is thus on "you will be buried." They further argue that the references "to sleep with" and "to be gathered to one's ancestors" are to be understood in terms of the continuing relationship existing between the living and the deceased. Family burials had important implications for the maintenance of that relationship. The deceased's well-being in the afterlife depended upon the descendants' preservation of the patrimonial estate.... The afterlife of the ancestors was contingent upon the association of parents, posterity, and property. ${ }^{49}$ King and Stager's argument means that Israelites practiced family tomb burials to perpetuate their patrimony and to keep the family ties unbroken even in death.

Stephen Cook holds a similar view by pointing out that because it was thought that priests would be defiled by contact with corpses (Lev 10:6; 21:1, 10-12; Ezek 44:25), funerary matters were not part of their duties. Thus, total care for the dead was the duty of the family and clan. Israelites therefore turned to their kin networks, not temples or priests, as their source of comfort, security, and hope of afterlife.$^{50}$ In early Jewish

\footnotetext{
${ }^{48}$ Philip J. King and Lawrence E. Stager, Life in Biblical Israel (Louisville, KY: Westminster John Knox Press, 2001), 365.

${ }^{49}$ Ibid., 365.

${ }^{50}$ Stephen L. Cook, "Death, Kinship, and Community: Afterlife and the 70 Ideal in Israel," in The Family in Life and in Death: The Family in Ancient Israel, ed. Patricia Dutcher-Walls (New York: T \& T Clark, 2009), 111.
} 
thinking, death could be resisted and ultimately vanquished "through faith in the bonds and ties of lineage and land-vested community.... They [family bonds and ties to ancestral territory] are so permanent, in fact, as to transcend Sheol's power and to point to Sheol's ultimate defeat." ${ }^{" 51}$ For the Israelites, "death meant the final change of address from the family home of the living to the family home of the dead." 52 This kinshipconsciousness transcended even death as

internment in a family tomb on family-owned land was of the utmost urgency (see 2 Kgs 9:10; Jer 8:2; 16:4 22:19; 25:33). Kin should lie buried together, traditional Israelites believed, especially closely related kin (see, e.g., 2 Sam 17:23; 19:37; 21:14; $1 \mathrm{Kgs} 13: 22$ ). This insured that after death family members would not be alienated from the insulating ties of communion with their kin. ${ }^{53}$

Pnina Galpaz-Feller also adds that "burial in a family tomb denoted permanence and a connection with the community. Sons' eventual burial in their ancestral grave symbolized continuity and connection to one's roots." ${ }^{54}$ Thus, even in death a kin-group longed to remain interconnected according to the same family and lineage ties that bound them in life. ${ }^{55}$ Such was probably why Jacob, while in Egypt, desired to be buried with his fathers in the cave in the field of Machpelah where Abraham and Isaac were buried (Gen 49:29-33; 50:1-10), or for Joseph making the sons of Israel swear an oath that they

${ }^{51}$ Cook, "Death, Kinship, and Community," 106.

${ }^{52}$ E. Bloch-Smith, "From Womb to Tomb: The Israelite Family in Death as in Life," in The Family in Life and in Death: The Family in Ancient Israel, ed. Patricia Dutcher-Walls (New York: T \& T Clark, 2009), 128.

${ }^{53}$ Cook, "Death, Kinship, and Community," 112.

${ }^{54}$ Pnina Galpaz-Feller, “'And the Physicians Embalmed Him' (Gen 50.2)," Zeitschrift für die alttestamentliche Wissenschaft 118 no. 2 (2006): 210.

${ }^{55}$ Cook, "Death, Kinship, and Community," 113. 
would carry his bones out of Egypt to the promised land when God delivered them, which they did (Gen 50:24, 25; Exod 13:19).

However, according to Philip S. Johnston, "gathered to one's fathers" does not refer to people's death or burial in family tombs since "gathered to one's fathers" is mentioned alongside the allusion to their death and burial (Gen 49:33; 50:13) and also because burial in a family tomb did not occur for some Israelites such as Moses, David, and Manasseh who were not buried in family tombs. ${ }^{56}$ Rather, he asserts that the phrase "gathered to one's people" likely "indicates joining one's ancestors in the afterlife." ${ }^{57}$ In this case, family members do not have to be buried in the same tomb to preserve their kinship relations in death.

My conclusion of the discussion on the nature of humans and the state of the dead in the Bible is that "death is an unconscious state for all people." ${ }^{58}$ As such, no part of humans survives death. At death, the body and the spirit cease to exist until the resurrection of the dead at the second coming of Christ (1 Thess 4:16-17). This has a direct implication for my perspective on "gathered to one's people." If no part of humans survives death, before the resurrection of the dead there is no form of afterlife in which the dead continue to interact. The expression "to be gathered to one's ancestors/people/fathers" is a Hebrew figure of speech (euphemism) which simply means

\footnotetext{
${ }^{56}$ Philip S. Johnston, Shades of Sheol: Death and Afterlife in the Old Testament (Downers Grove, IL: InterVarsity Press, 2002), 34.

${ }^{57}$ Ibid.

${ }^{58}$ General Conference of Seventh-day Adventists, Seventh-day Adventists Believe, 387. See Seventh-day Adventist Fundamental Belief number 26.
} 
"to die" and be buried just as one's forefathers were buried. ${ }^{59}$

\section{Belief in the Afterlife}

Various scholars assert that many early Israelites apparently believed in some form of life after death. This belief may have been developed from death-related concepts in the Mesopotamian and Canaanite cultures. Some scholars argue that the burial customs in the biblical world shed some light on Israelite belief about the afterlife. ${ }^{60}$ King and Stager are of the view that it was widely believed among early Israelites that "although death marked the end of life on earth, the deceased continued an ethereal existence in Sheol or in the family tomb. In other words, death is not extinction but transition to another kind of existence in Sheol."61 According to Rachel Hallote, when people died in ancient Israel, their roles in their community and family changed but did not disappear. ${ }^{62}$ Ralph Gower adds that in the early Israelite history, people generally believed that at death they would be "gathered to an underworld (Sheol), where people were shades (or shadows) of their past." ${ }^{\prime 3}$ For King and Stager, Sheol was not thought of as a place of punishment but as an exile from God, that is, those in Sheol had no contact with the divine presence. This new form of existence was a deplorable one to the Israelites for 315.

59،'Go to Thy Fathers” [Gen 15:15], Seventh-day Adventist Bible Commentary (SDABC), 1:314,

${ }^{60}$ See section on Burial Customs below.

${ }^{61}$ King and Stager, Life in Biblical Israel, 374.

${ }^{62}$ Rachel S. Hallote, Death, Burial, and Afterlife in the Biblical World: How the Israelites and Their Neighbors Treated Their Dead (Chicago, IL: Ivan R. Dee, 2001), 30.

${ }^{63}$ Ralph Gower, The New Manners and Customs of Bible Times (Chicago, IL: Moody, 2005), 67. 
whom the essence of life was the ability to praise God. ${ }^{64}$ Bible passages such as the following point out the inability of the dead to praise God from Sheol: "For the grave cannot praise you, death cannot sing your praise; those who go down to the pit cannot hope for your faithfulness" (Isa 38:18); "Among the dead no one proclaims your name. Who praises you from the grave?" (Ps 6:5); "I am set apart with the dead, like the slain who lie in the grave, whom you remember no more, who are cut off from your care. .. . Is your love declared in the grave, your faithfulness in Destruction?” (Ps 88:5, 11). Hallote therefore concludes that "if God does not remember the dead [Ps 88:4-5], clearly being dead was not desirable." 65

To make the existence in Sheol less deplorable, the dead were provisioned by the living for continued life, ${ }^{66}$ "relatives brought furnishings, vessels, and food stuffs into the tomb with the dead soul's body. Clay lamps in great numbers aimed to fend off Sheol's dark shroud. Such deposits, typical of Hebrew burials, show the concern of the living for the well-being of the dead. ${ }^{\circ 67}$ Providing the dead with everyday personal objects suggests that these were thought to be useful for them in their new form of existence. This points to the fact that the cult of the dead was one of the features of ancient Israelite society. ${ }^{68}$

\footnotetext{
${ }^{64}$ King and Stager, Life in Biblical Israel, 375.

${ }^{65}$ Hallote, Death, Burial, and Afterlife in the Biblical World, 53.

${ }^{66}$ Bloch-Smith, "From Womb to Tomb," 125.

${ }^{67}$ Cook, "Death, Kinship, and Community," 114.

${ }^{68}$ Naomi Steinberg, "Exodus 12 in Light of Ancestral Cult Practices," in The Family in Life and in Death: The Family in Ancient Israel, ed. Patricia Dutcher-Walls (New York: T \& T Clark, 2009), 92. See also Hallote, Death, Burial, and Afterlife in the Biblical World, 64.
} 
Hallote asserts that "the Cult of the Dead was probably one of the most active domestic cults of the biblical period." 69

Scripture is very clear: The dead lie unconscious in their graves (Ps 88:5, 11; Eccl 9:5, 6). This is why God undoubtedly prohibited any attempt to establish contact with the dead. ${ }^{70}$ With this revelation, it is strange that some Israelites were still actively involved in honoring those who know nothing and who no longer have a part in what happens among the living.

\section{The Resurrection of the Dead}

If there ever was a belief in a form of life after death among the Israelites, Daniel provided a significant correction with the revelation that "a resurrection would occursome to eternal life and some to eternal punishment (Daniel 12:2)." ${ }^{.71}$ Although Dan 12:2, "Multitudes who sleep in the dust of the earth will awake: some to everlasting life, others to shame and everlasting contempt," is the first unambiguous reference to the bodily resurrection of the dead, though there were hints to belief in the resurrection of the dead prior to this.

The dramatic image of the valley of dry bones brought back to life in Ezek 37:1-14 seems to point to God's promise of resurrecting the dead, especially in v. 13: "Then you, my people, will know that I am the LORD, when I open your graves and bring you up from them" (emphasis added). Another hint to the physical resurrection of the

\footnotetext{
${ }^{69}$ Hallote, Death, Burial, and Afterlife in the Biblical World, 54.

${ }^{70}$ See section on "Forbidden Death-Related Rituals" below.

${ }^{71}$ Gower, The New Manners and Customs of Bible Times, 67.
} 
dead is found in Isa 26:19: "But your dead will live, LORD; their bodies will rise-let those who dwell in the dust wake up and shout for joy-your dew is like the dew of the morning; the earth will give birth to her dead" (emphasis added).

Up to the time of the New Testament there were still different views as to the resurrection of the dead. Some, like the Sadducees, did not believe in the resurrection of the dead (Matt 22:23; Mark 12:18; Luke 20:27), while the majority seemed to believe in a corporate resurrection of Israel's dead. ${ }^{72}$ Even Jesus' inner circle of disciples seemed to have found his resurrection from the dead incomprehensible. According to Mark 9:9-11, when Jesus was coming down the mountain following his transfiguration he gave orders to Peter, James, and John "not to tell anyone what they had seen until the Son of Man had risen from the dead. They kept the matter to themselves, discussing what 'rising from the dead' meant" (emphasis added). Green argues that "this may have been because Jesus apparently spoke of the resurrection of an individual (that is, his own resurrection), whereas resurrection-belief in contemporary Judaism was corporate in its emphasis." ${ }^{, 73}$ Jesus later resurrected a widow's son (Luke 7:11-150), Jairus's daughter (Luke 8:40-56), and Lazarus (John 11:1-44) to show the possibility of an individual's resurrection.

\section{Rituals and Cultural Practices Surrounding Death in Scripture}

Scripture makes mention of several death-related practices. This section will focus on mourning the dead, burial customs, baptism for the dead, and three forbidden death-related practices in Scripture.

\footnotetext{
${ }^{72}$ Green, Body, Soul, and Human Life, 145.

${ }^{73}$ Ibid.
} 


\section{Mourning the Dead}

Mourning was an integral part of death rites. It was thought to be a way of honoring the dead. The occurrence of death was almost always accompanied by a time of wailing and intense lamentation (2 Sam 1:11-12; Acts 8:2). ${ }^{74}$ The wail was an announcement to neighbors that a death had taken place. Family members, friends, and neighbors usually joined this lamentation. ${ }^{75}$ In biblical times, "not to be mourned was a sign of punishment."76 Familiar biblical passages include: David mourning his son Absalom (2 Sam 18:19-33), Jairus's daughter's death (Mark 5:38), and mourning during and after the burial of Stephen (Acts 8:2). Rich families often hired professional mourners, generally women, to lament during funeral ceremonies (Jer 9:16-18; Amos 5:16). To further express that they were grief-stricken, people also wore sackcloth (camel or goat hair cloth garments) (2 Sam 3:31), beat their breast (Jer 32:9-12; 41:5-6), sat on the ground (Lam 2:10), and tore their garments (2 Sam 1:11-12; 3:31; Job 2:11-13). The dead were mourned for a week or longer (Deut 34:8; 1 Sam 31:13; Job 2:11-13). Jeremiah speaks of a funeral meal being provided to close the period of mourning (Jer 16:7).

\section{Burial Customs}

In biblical times, burial usually took place quickly after a person's death, usually

\footnotetext{
${ }^{74}$ King and Stager, Life in Biblical Israel, 372, 373.

${ }^{75}$ Gower, The New Manners and Customs of Bible Times, 68.

${ }^{76}$ Angela Standhartinger, "“What Women Were Accustomed to Do for the Dead Beloved by Them' (Gospel of Peter 12.50): Traces of Laments and Mourning Rituals in Early Easter, Passion, and Lord's Supper Traditions," Journal of Biblical Literature 129, no. 2 (2010): 560.
} 
the same day. ${ }^{77}$ Nevertheless, "a burial never took place on a Sabbath or holy day (John 11:39; 39:31."78 The proper burial of the dead was a fundamental concern in biblical times. It was dishonorable and even an insult to a dead person if his/her body was allowed to remain unburied and decay or be desecrated above the ground. ${ }^{79}$ This was particularly perceived as "a disgrace and a sign of divine judgment." ${ }^{\text {" }}$ "As a sign of divine punishment, king Jehoiakim, Jezebel and Ahab's descendants were to be improperly buried: "Therefore this is what the LORD says about Jehoiakim son of Josiah king of Judah: 'They will not mourn for him: 'Alas, my brother! Alas, my sister!' They will not mourn for him: 'Alas, my master! Alas, his splendor!' He will have the burial of a donkey_dragged away and thrown outside the gates of Jerusalem"” (Jer 22:18-19). Concerning Jezebel, it is written that " "dogs will devour Jezebel by the wall of Jezreel.' 'Dogs will eat those belonging to Ahab who die in the city, and the birds will feed on those who die in the country"' (1 Kgs 21:23-24).

There were three types of burial places: natural caves (Gen 25:9; 49:31; 50:13; John 11:38), artificially made caves (sepulcher; see Gen 49:29-32; Judg 8:32), or in simple graveyards. Although cremation was practiced by the Phoenicians who were Israel's neighbors, "the Israelites considered it as an act of desecration." ${ }^{81}$ The only mention of cremation was when the people of Jabesh Gilead "took down the bodies of

${ }^{77}$ King and Stager, Life in Biblical Israel, 364.

${ }^{78}$ Gower, The New Manners and Customs of Bible Times, 69.

${ }^{79}$ James M. Freeman, The New Manners and Customs of the Bible (Gainesville, FL: Bridge-Logos, 1998), 32, 33.

\footnotetext{
${ }^{80}$ King and Stager, Life in Biblical Israel, 363.

${ }^{81}$ Ibid., 364.
} 
Saul and his sons from the wall of Beth Shan and went to Jabesh, where they burned them. Then they took their bones and buried them under a tamarisk tree at Jabesh, and they fasted seven days (1 Sam 31:12-13). The rejection of cremation as a means of burial may have been tied to the belief that "man originated from the dust of the earth and to there he shall return. Therefore the body of the dead must reunite with the dust and earth from which it came." 82

When burial took place in natural caves, these were subsequently enlarged and provided with chambers where the bodies could be put. Because of the limited number of caves and also because members of the same family wanted to be buried in the same tomb, several dead were often buried in the same cave (e.g., Sarah, Abraham, Isaac, Rebekah, Leah, and Jacob were buried in the same tomb [Gen 23:14-16; Gen 25:9; 49:31; 50:13]; Gideon and Samson were each buried in their father's tomb [Judg 8:32; 16:31]). ${ }^{83}$ When the bodies had decayed the bones were removed and placed in a heap on the floor or deposited in a pit or ossuaries (stone jars) in order to make room for further burials. ${ }^{84}$ The simple graveyards were always located at the outskirts of residential areas. Exceptions were made for royalty who were usually buried within the city ( $2 \operatorname{Kgs} 2: 10) .{ }^{85}$ Bodies were often covered with spices before burial (John 19:40). However this was not the same as the embalmment practiced by the Egyptians. The Israelites did not practice embalmment. Pnina Galpaz-Feller argues that because embalmment was the exclusive

\footnotetext{
${ }^{82}$ Galpaz-Feller, “And the Physicians Embalmed Him,” 209.

${ }^{83}$ Bloch-Smith, "From Womb to Tomb," 123.

${ }^{84}$ King and Stager, Life in Biblical Israel, 364.

${ }^{85}$ Bloch-Smith, "From Womb to Tomb," 127.
} 
domain of the Egyptians in the ancient world, the embalmment of Jacob (Gen 50:2) was an adoption of Egyptian practices rather than a way to preserve his body so that it could be well kept for burial in the land of Israel. No special significance was given to preservation of the human body at death among the Israelites, ${ }^{86}$ contrary to the Egyptians for whom the practice of embalmment was linked with the belief that there was continued existence after death and that without the body being preserved intact, there could be no further existence after the passage from this world to the next. ${ }^{87}$

According to the laws of the Pentateuch relating to ritual cleanness and uncleanness, the Israelites could contract uncleanness through contact with dead bodies (Num 5:2-3; Lev 21:1-4, 11). Whereas uncleanness conveyed by touching an unclean thing usually lasted until evening (Lev 15:1-11, 19-24), touching a human corpse made one unclean for seven days (Num 19:11). Since touching dead bodies would make priests ceremonially unclean thus excluding them from their duties in the sanctuary, they were not to be involved in burial rites except for those of their close relatives, that is, their mother, father, son, daughter, or unmarried sister (Lev 21:1-3). The high priest was not to enter a place where there was a dead body or make himself ceremonially unclean even for his father or mother (Lev 21:11). Ceremonial uncleanness placed any person under the threat of divine retribution, even death, if that person were to approach the sanctuary without purifying themselves (Lev 15:31; 22:3-9; Num 19:13). Uncleanness and the threat associated with it remained until the necessary steps for purification were taken

\footnotetext{
${ }^{86}$ Galpaz-Feller, ““And the Physicians Embalmed Him' (Gen 50.2),” 209, 211.

${ }^{87}$ Pnina Galpaz-Feller, The Exodus from Egypt: Reality or Illusion (Exodus 1-15) (Tel Aviv: Schocken, 2002), 13.
} 
(Lev 17:16; Num 19:12-13). As a result, "where contraction of impurity occurred, it was obligatory that the unclean person avoid that which is holy and take steps, involving the rituals for disposal of impurity [e.g., Lev 16:3-4; Num 8:5-8; 19:1-20], to return to a state of cleanness." 88 That might have been a reason why funerary matters were generally the duty of the bereaved family and clan. ${ }^{89}$ The rules of purity in connection with dead bodies convey in a symbolic way that the God of life is completely separated from anything that has to do with death. They also highlight the concept of the holiness of God. The purity laws suggest that "mortality involved in the birth-death cycle of human beings is opposed to divine holiness, which is characterized by life." 90 Consequently, "the unclean are excluded from the tabernacle, the symbolic dwelling place of God (Num 5:3; Lev 15:31). ${ }^{, 91}$ Furthermore, just as sacrificial offerings were to be without defect (Lev 1:3, $10 ; 3: 1,6 ; 4: 3)$, God's people were also to worship him with their lives devoid of impurities.

\section{Baptism for the Dead}

A new death-related ritual, baptism for the dead, is introduced in 1 Cor 15:29:

"Now if there is no resurrection, what will those do who are baptized for the dead? If the dead are not raised at all, why are people baptized for them?" (emphasis mine).

What is baptism for the dead and why were people observing this rite? The proper

\footnotetext{
${ }^{88}$ Joe M. Sprinkle, "The Rationale of the Laws of Clean and Unclean in the Old Testament," Journal of the Evangelical Theological Society 43, no. 2 (2000): 641.

${ }^{89}$ Stephen L. Cook, “Death, Kinship, and Community,” 111.

${ }^{90}$ Gane, Leviticus, Numbers, 659.

${ }^{91}$ Sprinkle, "The Rationale of the Laws of Clean and Unclean in the Old Testament," 649, 652.
} 
understanding of baptism for the dead has been a continuing challenge to New Testament scholars. No single interpretation of this form of baptism has gained a general consensus. $^{92}$

Richard DeMaris contends that baptism on behalf of the dead was a peculiar Corinthian practice that was little known elsewhere in the early church. He argues that as such, baptism on behalf of the dead should not be called a Christian practice. He points out that "Christianity, along with its sister religion, Judaism, was only forming in the first and second centuries. So to label first-century phenomena Christian or Jewish is historically inaccurate." 93

In the introduction of his study on 1 Cor 15:29, Bernard Foschini posits that "the phrase baptizesthai hyper tōn nekrōn of 1 Cor. 15:29 has always been obscure. It can justly be labeled as a 'crux interpretum.' An all around satisfactory explanation of the words has never ceased to tantalize exegetes." ${ }^{94}$ In the same vein, Richard Carlson comments that "despite dozens of proposed solutions, the reference itself [baptism for the dead] is simply so obscure and our knowledge so limited that we cannot discern what this rite actually involved or meant." 95 He concludes by stating that whatever "baptism on behalf of the dead" may have meant, it is presented by Paul as a baptismal rite done in

\footnotetext{
${ }^{92}$ DeMaris, The New Testament in Its Ritual Context, 57.

${ }^{93}$ Ibid., 13.

${ }^{94}$ Bernard Foschini, "Those Who Are Baptized for the Dead” 1 Cor. 15:29: An Exegetical Historical Dissertation (Worcester, MA: Heffernan Press, 1951), 1. 261.

${ }^{95}$ Richard P. Carlson, “The Role of Baptism in Paul’s Thought,” Interpretation 47 (July 1, 1993):
} 
anticipation of the resurrection of the dead at the second coming of Christ. ${ }^{96}$

For Mormon scholars such as Roger D. Launius and Robert E. Clark, baptism is an indispensable means of salvation; in other words, to be saved, a person must be baptized. They understand the phrase "baptism on behalf of the dead" as referring to the baptism of dead people by proxy, that is, a vicarious rite practiced by the living for the benefit of the physically dead. Launius writes that "those who had died without accepting the gospel will be taught after death, and others could be baptized on earth in their stead." 97

Following the same line of argument, Clark argues that because baptism is a physical ordinance, it has to be performed in the flesh. Those who have died without an opportunity to hear the gospel and be baptized thus need some means of access to this ordinance. This is accomplished by having a baptized member of the church stand as proxy for the deceased individual, allowing his or her body to be baptized for and in behalf of the one who no longer has a body. ${ }^{98}$

Another scholar, Daniel Joyce, is in full agreement with the Mormon view. He emphasizes the proposition hyper (for) in baptizesthai hyper tōn nekrōn and concludes that this "shows us that what is done is done for the dead and not for the living." 99

If among the Corinthian believers "baptism for the dead" meant baptism for the dead by proxy, DeMaris contends that they might have been influenced by the Greco-

\footnotetext{
${ }^{96}$ Carlson, "The Role of Baptism in Paul's Thought," 261.

${ }^{97}$ Roger D. Launius, “An Ambivalent Rejection: Baptism for the Dead and the Reorganized Church Experience,” Dialogue: A Journal of Mormon Thought 23, no. 2 (Summer 1990): 62.

${ }^{98}$ Robert E. Clark, "Baptism for the Dead and the Problematic of Pluralism: A Theological Reconfiguration," Dialogue: A Journal of Mormon Thought 30, no, 1 (Spring 1997): 108.

${ }^{99}$ J. Daniel Joyce, "Baptism on Behalf of the Dead: An Interpretation of I Corinthians 15:29-34," Encounter 26, no. 2 (Spring 1965): 273.
} 
Roman religious environment prevalent in Corinth. He points out that

both ancient Greek and Roman societies devoted considerable resources to the dead, in part for fear of them but primarily because the living were thought to be obligated to help the deceased become integrated into the realm of the dead. Such help was crucial, for the moment of death was thought to mark only the beginning of a long and sometimes difficult transition to the next world. In Greece this help began with proper mourning and burial rites and continued for some time in the form of periodic commemorations of the deceased, such as festivals. Remembering the dead also involved visiting the grave, a visit that might include sacrifices and feasts held for them. A few Greek graves even had feeding tubes so that blood offerings and libations could be communicated directly to the deceased. Many of these practices appear to reflect a belief that the dead could benefit directly from actions performed on their behalf. ${ }^{100}$

If "baptism for the dead" meant baptism for the dead by proxy to the Corinthian

believers, it is their concern for the well-being of their dead relatives or friends that might have led them to syncretize their Christian faith.

Other scholars such as Bernard Foschini and Joel White reject the idea that baptism for the dead refers to a baptism by proxy for the well-being of the dead.

Although Foschini started his argument by stating that the phrase "baptism for the dead" was obscure, he concludes by arguing that the word "dead" in baptism for the dead should be understood as one's own dead body, and as such, the phrase baptism for the dead can be understood as referring to baptism for the benefit of one's own self, that is, to be part of the everlasting glory promised by God (Rom 6:26). ${ }^{101}$

Joel White seems to interpret the proposition "for" (hyper) in "for the dead" as meaning "because of," "for the sake of," or "on account of" the dead. With this

\footnotetext{
${ }^{100}$ Richard E. DeMaris, "Corinthian Religion and Baptism for the Dead (1 Corinthians 15:29): Insights from Archaeology and Anthropology," Journal of Biblical Literature 114, no. 4 (Winter 1995): 663.

${ }^{101}$ Foschini, “Those Who Are Baptized for the Dead, " 97, 98.
} 
understanding, 1 Cor 15:29 will therefore read, "Now if there is no resurrection, what will those do who are baptized because of/for the sake oflon account of the dead? If the dead are not raised at all, why are people baptized because of/for the sake of/on account of them?" For him, baptism for the dead was not a vicarious rite but rather refers to the rite of regular baptism undertaken by some people as a result of their affection and respect for those who are now dead. ${ }^{102}$

Regardless of the suggested interpretations of 1 Cor 15:29, it is important to not lose sight of the fact that the apostle Paul is likely not recommending the practice of baptism by proxy for the dead. It is more likely that he is simply referring to an existing practice among Corinthian believers who had copied this heretical practice from pagans. ${ }^{103}$ It would be unlikely for Paul "to cite a pagan or heretical practice in support of a fundamental Christian doctrine." ${ }^{104}$ Further, Paul could not have argued in favor of a belief that the dead could benefit directly from actions performed on their behalf by the living based on his arguments in Rom 14:12 that "each of us will give an account of ourselves to God," and "we must all appear before the judgment seat of Christ, so that each of us may receive what is due us for the things done while in the body, whether good or bad" (2 Cor 5:10). Romans 14:12 and 2 Cor 5:10 highlight the fact that when it comes to salvation, we are all accountable for ourselves. When someone dies, nothing can be done by the living to change one's fate before God. Death marks the close of

\footnotetext{
${ }^{102}$ Joel R. White, "“Baptized on Account of the Dead': The Meaning of 1 Corinthians 15:29 in Its Context," Journal of Biblical Literature 116, no. 3 (Fall 1997): 498.

${ }^{103}$ DeMaris, “Corinthian Religion and Baptism for the Dead (1 Corinthians 15:29)," 663.

104“Baptized for the Dead” [1 Cor 15:29], Seventh-day Adventist Bible Commentary (SDABC), $6: 807$.
} 
individual human probation. Finally, baptism requires an act of faith; each person must personally believe in Christ and confess their sins (Acts 2:38; 8:36, 37; Mark 15:16). In harmony with the New Testament theology of baptism (Acts 2:38; 8:36, 37; Mark 15:16) and the main theme under discussion here (the resurrection), the phrase "those who are baptized for the dead" likely refers to people who, after the death of a Christian friend or relative, are motivated to be baptized in order to be united with them at the resurrection.

\section{Forbidden Death-Related Rituals}

Israel was strictly forbidden by God to practice several death-related rituals. Among these were cutting their bodies for the dead, cutting their hair as a sign of mourning, and involvement in spiritism. This section will consider the reasons for these prohibitions.

\section{Cutting One's Body for the Dead- Leviticus 19:28}

Various laws are outlined in Lev 19. The main reason why the Israelites needed to obey these laws is given in v. 2, "Speak to the entire assembly of Israel and say to them: 'Be holy because I, the LORD your God, am holy." Leviticus 19 is therefore a call to imitate God by embracing a lifestyle of holiness. Mark Rooker observes that Lev 19 "perhaps better than any other [chapter] in the Bible, explains what it meant for Israel to be a holy nation." 105 The prohibitions contained in the laws outlined in Lev 19 were intended to set Israel aside as a holy nation. Holiness meant imitating God rather than

\footnotetext{
${ }^{105}$ Mark F. Rooker, Leviticus. The New American Commentary, vol. 3A (Nashville, TN: Broadman \& Holman Publishers, 2000), 250.
} 
their surrounding nations. Leviticus 19:28 says, "Do not cut your bodies for the dead or put tattoo marks on yourselves. I am the LORD." This speaks against "pagan mourning practices involved in ancestor worship." ${ }^{" 106}$ In pagan mourning rituals, mourners often cut their body and shed their blood to appease the demons from tormenting their dead. ${ }^{107}$ Mourning the dead was not forbidden to Israelites, "only its identification with the pagan rites carrying idolatrous connotations." 108

\section{Spiritism-Leviticus 20:6, 27; Deuteronomy 18:10-13}

Leviticus 20 continues with the holiness theme begun in Lev 19. The motivation for keeping the laws outlined here is given in vv. 7, 8, and 26: "Consecrate yourselves and be holy, because I am the LORD your God. Keep my decrees and follow them. I am the LORD, who makes you holy. You are to be holy to me because I, the LORD, am holy, and I have set you apart from the nations to be my own." Because Yahweh is the God of Israel, they must be holy. Verses 7 and 8 also point out that the Israelites are called to protect their holy status from defilement. Refraining from practices in which the dead are consulted or worshiped (v. 23; Deut 18:10-13) is indispensable for attaining holiness (Lev 20:6, 27). ${ }^{109}$ To remain in the land God gave them (v. 22), the Israelites were to be

\footnotetext{
${ }^{106}$ Roy Gane, Leviticus, Numbers, The NIV Application Commentary (Grand Rapids, MI: Zondervan, 2004), 340.

${ }^{107}$ Walter C. Kaiser, "The Book of Leviticus," The New Interpreter's Bible (NIB) (Nashville, TN: Abingdon, 1994), 1:1135.

${ }^{108}$ Ibid.

${ }^{109}$ Jacob Milgrom, Leviticus 17-22, The Anchor Bible (New York: Doubleday, 2000), 1684.
} 
pure by refusing to consult mediums or spiritists. ${ }^{110}$ Although divination and ancestor worship were common practices in the nations surrounding Israel, ${ }^{111}$ the Israelites were not to consult the occult world because they were given a better revelation by God. ${ }^{112}$

\section{Shaving the Head for the Dead- Deuteronomy 14:1-2}

In line with God's demands in Lev 19 and 20, Deuteronomy also sets forth specific guidelines for holy living. Deuteronomy 14:1-2 "speaks of holiness as a quality that Israel possesses." 113 Although shaving the hair is not completely forbidden by Scripture, as a holy people, the Israelites were not to do so in connection with mourning rites for the dead. Such "activities were practiced by pagans especially during times of mourning for the dead." 114 Just as physical contact with a corpse was deemed defiling (Lev 11:24-40), so was any spiritual attempt to establish contact with the dead. ${ }^{115}$ Commenting on Deut 14:1-2, Daniel Block notes that "non-Israelites believed the deceased continued to exercise both beneficent and malevolent power over the living, and that the favorable influence of departed ancestors could be secured through mortuary rites" $" 116$ such as cutting their bodies or shaving their heads for the dead.

${ }^{110}$ Rooker, Leviticus, 271.

${ }^{111}$ Gane, Leviticus, Numbers, 341.

${ }^{112}$ Kaiser, "The Book of Leviticus," 1:1135.

${ }^{113}$ Daniel I. Block, Deuteronomy, The NIV Application Commentary (Grand Rapids, MI: Zondervan, 2012), 343.

\footnotetext{
${ }^{114}$ Rooker, Leviticus, 262.

${ }^{115}$ Block, Deuteronomy, 344-345.

${ }^{116}$ Ibid., 344.
} 
The three forbidden mortuary rites surveyed above share the common reason why the Israelites were not to practice them. Because the Israelites belonged to a holy God, they were to guard themselves against any form of the cult of the dead.

\section{Conclusion}

Community-centeredness was of utmost importance to the Israelites. They not only promoted it among the living, they also hoped for its continuation in death. Proper death and burial rituals were perceived as the means of making kinship relationships transcend life.

The Israelites' concern for the well-being of their dead, their hope to be united with them, and the influence of their pagan neighbors may have led some to practice the cult of the dead as a means of keeping the doors of communication open between the living and the dead. This was practiced either out of fear of retribution from the dead or out of a desire to seek their guidance since they were believed to know everything. ${ }^{117}$ As a result, although the official religion of Israel condemned and even tried to eradicate any form of attempted contact with the dead (Lev 19:28, 31; 20:6, 27; Deut 14:1-2; 18:1011), the practice persisted in spite of the threat of severe punishment (e.g., Lev 18:29; 20:27). By defiling themselves with the cult of the dead, the Israelites erased the differences between them and their polytheistic Canaanite neighbors. ${ }^{118}$

If "baptism for the dead" in 1 Cor 15:29 was understood and practiced by the Corinthian believers as baptism for the dead by proxy, it is likely that their concern for

\footnotetext{
${ }^{117}$ Hallote, Death, Burial, and Afterlife in the Biblical World, 60, 61.

${ }^{118}$ Ibid., 64.
} 
the well-being of their dead loved ones may have led them to syncretize their Christian faith. If this was the case, they might have been influenced by the Greco-Roman religious environment in which considerable resources were devoted to the dead to help them transition to the realm of the dead. ${ }^{119}$

The next chapter will report on my filed research findings and the challenges that were brought to light in the process.

${ }^{119}$ DeMaris, "Corinthian Religion and Baptism for the Dead (1 Corinthians 15:29)," 663. 


\section{CHAPTER 4}

\section{RESEARCH FINDINGS AND CHALLENGES}

\section{Introduction}

I spent the month of May 2014 in Burkina Faso doing field research in three Lobi communities concerning their funeral rites of passage. I conducted interviews and observed a burial service. My findings broadened my understanding of the sociocultural significance of the Lobi funeral rites as well as the challenges they pose to Christian mission among the Lobi.

\section{Description of Research Process}

I interviewed three Lobi religious leaders, and 12 Adventists. Each of the respondents was interviewed individually. The Adventists I interviewed were divided into three groups: (1) those who had taken part in the Lobi funeral rites before becoming Adventists, (2) those who had taken part in the Lobi funeral rites after becoming Adventists, and (3) those who are currently being or who have been pressured to participate in the Lobi funeral rites.

\section{Interviews with Lobi Religious Leaders}

The three Lobi religious leaders I interviewed were asked six questions. Their answers were the same for the first four questions. Diverging views emerged in their 
answers to questions 5 and 6. Following are the questions I asked and the synthesis of the answers that were provided.

Question 1-What is the Lobi people's perception of death?

Death is the fate that awaits all humans. No one can live without one day "tasting" death. Death creates a disharmony between humans. When a person dies, their relatives always inquire about the causes of death. In most of the cases, it is revealed that a "wicked" member of the community caused the death. This revelation inevitably creates disharmony and bitter relationships among members of the community. They also believe that the dead are not dead; they have only moved to another form of existence from which they continue to participate in the affairs of the living. They are still with us. They hear us.

Question 2-Is death always of a natural cause?

All three Lobi religious leaders believe that there is no natural illness and therefore no natural death. Illness and death always have hidden causes: a wicked person, a spirit, or an offended ancestor. It is the responsibility of the deceased's relatives to find out who, and never what, killed him/her. The cause of death can be known through divination or by directly interrogating the dead person.

Question 3-Why do you perform funeral rites for those who die?

Funeral rites are performed for one main reason: for the dead person to get to balbulah (the abode of the ancestors) and be accepted by the ancestors as one of them. Balbulah is thought to be a perfect replica of this life but with better living conditions. Without funeral rites, the dead may not reach balbulah.

The land of the living and that of the dead (ancestors) is separated by a river. If 
dead people's funerals are not done according to the prescription handed down by the ancestors, they cannot cross that river and get to balbulah. There is no rest for such dead people. They will spend their entire existence as wandering spirits who hurt the living. Question 4-Are funeral rites done for every single person who dies?

Funeral rites are not automatically done for every person that dies. When a death occurs, the ancestors are consulted to find out if the deceased deserves funeral rites. No funeral rite is performed for people who die at the dyoro (initiation rites). Such people are not welcome in balbulah. The relatives of those who die by lightning, drowning, or suicide must appease the ancestors and the earth before their dead can be buried. If the ancestors and the Mother Earth are not appeased, the community will suffer a drought. Death by lightning, drowning, or suicide is viewed as a bad death (an improper way of dying). There is, therefore, no funeral rite for this category of death.

Also, not all funeral rites lead to the ancestralisation of the dead. To become an ancestor, one should live an exemplary life (e.g., not a witch), be initiated, and be married with children.

Question 5-Do you think that all Lobi, whatever their religion, should fully take part in these rites? Why?

Two opposing views emerged during my interviews with the three Lobi religious leaders.

Two of the religious leaders said that when they die, they do not want their children who are of other religious faiths to be forced to perform the rites associated with the traditional Lobi funerals. These leaders feel that if they did not oppose their children's conversion to other religions, there is no reason for the children to submit to the traditional Lobi funerals at their (parents') death. However, both of the leaders insisted on 
only one thing: all their children, irrespective of their faiths, should, at least, be present at their funerals and help each other to take care of the well-wishers.

The third religious leader is of the view that all true Lobi must fully participate in their parents' funeral rites, i.e., throwing cowries to their parents' dead bodies, shaving their head as a sign of bereavement, and whitewashing their bodies. He expects all his children, irrespective of their religion, to submit themselves to the way of the ancestors at his death. I explicitly asked him if he expects that from his four children who are Seventh-day Adventists. He answered that at his death, all his children, including those who are Seventh-day Adventists, "must lay aside their acquired religious beliefs and fully submit themselves to the Lobi tradition." He insisted that it is a duty of all his children to honor him and make him happy both in this life and in death. For him, a child who refuses to do so has neglected and even denied him his honor and will inevitably suffer the consequences of his unhappiness in this life. Besides, he threatened to not welcome them in balbulah.

Question 6-How should the community view and treat children who refuse to submit to tradition at their parents' funerals?

Here again, the first two religious leaders said that the community should respect each person's religious choice. The third religious leader believes such children should be excommunicated because they turned their back on the ways of their society.

Interviews with Lobi Seventh-day Adventists

\section{Members Who Took Part in Lobi Funeral Rites before Conversion}

Six members were interviewed who had taken part in Lobi funeral rites before becoming Adventists but who refuse to do so after their conversion. The five questions 
each respondent was asked and the synthesis of their answers is as follows.

Question 1-What motivated you to participate in funeral rites?

All the respondents said that they were told from a young age that this was the right way of being a Lobi. A true Lobi was described to them as one who strictly follows the traditions handed down to the community by the ancestors. Full participation in one's parents' funerals is the clearest way for a child to demonstrate that he/she truly honors them.

There was also a subtle threat that led them to take part in all the rites. The respondents were told that if they refused to participate in people's funeral rites, the community would not participate in their parents' funerals. This caused their parents to put more pressure on them. They were also told that their participation in other people's funerals was an investment they were making toward their own funerals. In other words, for someone to have good funerals, they had to participate in other people's funerals. Finally, they were told that if they refused to submit to tradition at the death of their parents, or husbands, they would be rejected and would not succeed in life.

Question 2-What would have happened if you had refused to participate?

Members of the deceased's family who refuse to submit to the way of the ancestors bring shame on their entire family. Such people are seen as rebels against society. They are rejected and even accused of being responsible for the death.

Question 3-Why do you refuse to participate in Lobi funeral rites today?

Three main reasons were given why this group of Adventists would no longer participate in the traditional Lobi funeral rites: (1) the biblical teaching that the dead are unconscious and aware of nothing that happens among the living, (2) the unbiblical 
practices associated with traditional funeral rites such as divination, interrogation of the dead, and the shaving of the head in honor of the dead person, and (3) a desire to be examples of faithfulness to other church members.

\section{Question 4-What helps you stand firm?}

All of the respondents said they will continue to stand firm because of their faith in God, two said the example of a faithful few help them to stand firm, and two others (a man and a woman) said they will continue to stand firm because of their faith in God and also because they have already experienced God's power as superior to that of local deities.

I asked these last two respondents to relate how they experienced God's power. The woman lost her husband several years ago and refused to perform the traditional funeral rites such as having her head shaved and her body whitewashed. Not long after, she fell critically ill. People started saying that she was so sick and would soon die because she refused to submit herself to the way of the ancestors. She requested that the church pray that God may use her illness to glorify his name by showing to the whole community that he can save those who trust him from the curses of other gods and ancestors. The church prayed, and she was completely healed; to the amazement of everybody in her village. She told me that she has never been threatened again. She uses her story to encourage others to remain faithful to Christ.

The second respondent told me that one of his clan's taboos forbids him from touching a monkey. To make ends meet, he asked an Adventist missionary to employ him as his house helper. The missionary had several monkeys and one of his duties was to take care of them. One day as he was feeding the monkeys, one broke loose and ran into 
the village and took refuge on top of the idol that is in his father's shrine. When he tried to enter into the shrine to catch the monkey, onlookers told him that he was going to die. He stopped right there, said a prayer, and went in and caught the monkey and went back to the missionary's house. Early the next morning, people waited to hear news of his death. Seeing him alive and well, they confessed that he serves a powerful God. That incident strengthened his faith and continues to help him stand firm for his faith.

\section{Members Who Took Part/Are Taking Part in Lobi Funeral Rites after Becoming Adventists}

In my interviews, only two respondents (a man and a woman) told me that they have been involved in the traditional Lobi funeral rites. I was told about others who frequently do, but they refused to meet me for an interview. What surprised me was that the man is a former employee of the church and the woman is married to a prominent church leader currently employed by the church.

I interviewed them individually. Below is the synthesis of their answers to my questions.

Question 1-What motivated you to participate in funeral rites in spite of being an Adventist?

The woman told me that she was compelled to do so by her family at the death of her father. She said she had no choice but to shave her head in honor of her dead father. (Her husband told me that he will also do so at the death of his father). The second respondent told me that he has always taken part in funeral rites because of the following reasons: (1) tradition requires it of him, (2) his love for the Lobi culture, (3) he wants his funerals to be done according to the Lobi tradition, and (4) he believes that the dead are not dead. 
Question 2-Are there practices conflicting with biblical principles? If yes, describe them.

All the respondents said that there are practices in the traditional Lobi funeral rites that conflict with biblical principles. They mentioned divination, interrogating the dead, throwing cowries at the deceased's feet to help them pay their way to balbulah, shaving the head in honor of the dead, and dancing for the dead as unbiblical practices. This was when I learned that people vigorously dance at funerals as a way of sending the deceased on their journey to balbulah.

Question 3-Do you regret participating in these rites? Why?

The female respondent regrets not being able to stand firm for her faith. She told me that after her father's funeral, she fell sick and she attributes that to her unfaithfulness to God. The church prayed for her and she was healed.

The male respondent has no regret for his continual participation in funeral rites. He insisted that it is the right thing to do for every true Lobi.

Question 5-Should other Lobi Adventists participate in funeral rites? Why?

On the basis of her experience, the female respondent said that Adventist should not participate in the traditional funeral rites because the core rites are incompatible with biblical teachings. She also pointed to the fact that God's power is able to protect believers against evil powers.

The male respondent insisted that all real Lobi must obey their tradition in general and at the death of their parents in particular. He concluded that there is nothing wrong with that although he is well aware that traditional funeral rites contain unbiblical elements. 


\section{Members Experiencing Pressure to Participate in Lobi Funeral Rites}

Four church members who are currently being or have been pressured to participate in Lobi funeral rites were interviewed in this last category. All of them have categorically refused, despite pressures and threats, to take part in the traditional Lobi funeral rites. I wanted to further understand the type of pressure they were experiencing, as well as, what they thought would help them stand firm in their faith. Following is the synthesis of my interviews with them.

Question 1-What kinds of pressures are you experiencing now to participate in funeral rites?

I have discovered that all the respondents in this category have emotional and financial pressures. At least two are still dependent on their families for basic needs such as food and school fees. These members are being accused of preferring their Christian faith to their families and their community. Some said that they are not even considered to be Lobi; they are referred to as "Dioula," another tribe that currently resides in their village. One of the respondent has been told that he was not doing well in his business as the result of the curse he incurred by refusing to perform the required rites at the death of his father. Another respondent has even been told that his eternal salvation was at stake for refusing to honor his father and the tradition.

Question 2-Why do you refuse to participate in funeral rites?

The four respondents base their refusal to participate in the traditional Lobi funeral rites on the fact that the core rites (first and second funeral rites) all contain unbiblical practices. They consider participating in these rites as a violation of God's Word and one of the main beliefs of the church. They pointed to the following as what 
they see as contradicting their Adventist beliefs: divination and interrogating the deceased to find the cause of death, throwing cowries to the deceased as a way of contributing to the success of their journey to balbulah (the land of the ancestors), dancing to set the deceased on their journey to balbulah, head shaving as a sign of mourning and honoring the dead, and whitewashing the widows and orphans as a way of protecting them against harm from the deceased (this implies that the dead are not really dead).

Question 3-What helps you resist the pressure?

The respondents mentioned the following as those things that help them resist the pressure to take part in funeral rites: faith in God, desire to be faithful to God, the encouragement from other church members, the example of other church members, desire to be an example to others, and the power of God to protect.

Question 4-How long can you refuse participating in the traditional funeral rites for the sake of your religious beliefs?

The respondents said they have counted the cost of discipleship and that they were willing to continue to suffer for their faithfulness to God.

Question 5-What kind of support are you hoping for from your church leaders?

The respondents in this group of interviewees expect church leaders to lead by example, i.e., stand firm for their faith; conduct "good" Bible studies to ground members in the Word of God, invest time and resources in discipling new converts, and identify with other members in times of crisis.

\section{Observation of Public Behavior at a Funeral}

The last day of my field research, I traveled with my informant to conduct further interviews in another Lobi village. Upon arrival, we were informed that a death had just 
occurred in a neighboring village. A nine-year-old boy had died after a long illness. His father is an Adventist but his mother is not. Usually funeral ceremonies take place in the paternal compound but this was not so in this case. I was told that when the boy died in the hospital, his mother ran straight to her parents' compound. Because the husband had not paid the dowry, it was compulsory that his son's corpse be taken to his in-laws.

When we arrived there the body was laid on a bed under a tree surrounded by women. Men and women sat far apart from each other. Women were the ones wailing, walking to and fro, beating their chest or with both hands on their heads. I was told that it was a distinctive sign of misfortune. I met the boy's mom and presented to her my condolences. I was also led to his dad who was sitting almost alone under a tree. He was visibly in pain for losing his only child but also because none of his next of kin could be in charge of his son's funerals. Since the deceased boy's mother was not an Adventist and his father had not paid the bride price, the mother's family was to decide on the type of funeral ceremony they wanted for him. After some discussion between a group of Adventists and the woman's family, it was decided that the boy's funeral would be led by Adventists. This was a big relief for the church for two reasons: there would be no animal sacrifice and the boy's father was not going to completely lose face.

Once the church was granted permission to conduct the funeral service, a prayer was said and the choir began singing. Songs were accompanied with drums and clapping of hands. My translator told me that the songs express sorrow for the loss but also hope for the resurrection of the dead. After about 45 minutes of singing, the district pastor preached on the state of the dead and the hope of the resurrection. After the sermon, another prayer was said and the corpse was taken with the bed and we walked to the 
cemetery. A graveyard service was conducted before the burial. We returned home after the burial to present our condolences to the wife's family. Before departing, church leaders contributed money for the family.

\section{Biblical and Missiological Challenges}

On the basis of my field research, I see at least five major reasons why some Lobi Adventists continue to take part in their traditional funeral rites: (1) the fear of evil powers, (2) societal pressure, (3) the poor discipleship of some converts, (4) lack of worldview change, and (5) the inconsistency of some church leaders. All five of these reasons make it easy for some members to succumb to syncretism in times of crises.

\section{The Fear of Evil Powers}

The fear of evil powers among the Lobi is very palpable. Shrines dedicated to deities and spirits are present in homes and public places in the villages. Every misfortune is interpreted as the spirits' unhappiness with humans. In times of crises, the natural tendency is to pay these deities and spirits "their dues" to ensure their favor and benevolence. ${ }^{1}$ In such times, it is not uncommon to find church members reverting to unchristian practices as their last resort to meet some existential needs. Power objects (e.g., amulets) are worn, sacrifices are made, rituals are performed, and people of power (e.g., diviners) are consulted in an attempt to ward off evil powers in order to be successful in life.

\footnotetext{
${ }^{1}$ Triebel, "Living Together with the Ancestors," 187-189.
} 


\section{Societal Pressure}

Societal pressure to conform to tradition is exercised on individuals in five main ways: (1) In the traditional Lobi context, the whole of life is community centered. As a result, it is thought that the Lobi identity is inseparable from participation in community rituals. $^{2}$ (2) Church members who still depend on their non-Adventist families for meeting their daily needs often succumb to the societal pressure to conform to traditional customs and practices. (3) Since becoming an ancestor also depends on the proper performance of specific rites in which immediate family members of a deceased must take part, some parents threaten to curse their children in case they refuse to follow tradition at their death. (4) The social penalty for refusing to participate in some rituals could lead to the rejection of or complete indifference toward those who dare to defy tradition. (5) Misfortunes in the community are sometimes interpreted as the consequence of the ancestors' unhappiness with some community members' failure to respect and obey them. ${ }^{3}$ Also, failure to take part in funeral rites may be taken as an indication of possible involvement in the death. ${ }^{4}$ Therefore, because of the fear of being blamed for the death of a person or for the community's hardships, some people prefer to submit to tradition.

\section{Poor Discipleship of Some Converts}

The discipleship process of many Lobi converts to Adventism may be biblically

\footnotetext{
${ }^{2}$ Bognolo, Lobi, 8, and Ovesen, "Initiation: A Folk Model among the Lobi," 164.

${ }^{3}$ Triebel, "Living Together with the Ancestors," 189.

${ }^{4}$ Goody, Death, Property and the Ancestors, 51, 86.
} 
faithful to some extent but not culturally appropriate. Emphasis is only put on the cognitive knowledge about biblical truth. Although important, doctrinal clarity does not effectively speak in this context to people's existential needs of protection from curses and evil spiritual powers. Also, despite the fact that emphasis is put on doctrinal correctness, it is usually done hastily, with the event of baptism marking the end of the process. This poor discipleship of converts is unable to help them stand firm for their faith in times of crises.

\section{Lack of Worldview Change}

Worldview is the underlying, deep-level, unconscious, and unchallenged assumptions about reality upon which culture is built. It determines beliefs, ideas, feelings, and values which are manifested in visible behaviors, structures, and various products in the society. Before people adopt a new approach to life, they must experience dissatisfaction with the status quo, know of a better way, and see how to take the first steps. $^{5}$

The implication of this in cross-cultural ministry context is that we should not be content with changes in converts' behavior as the single sign of conversion. Such changes are important but they do not necessarily mean that underlying beliefs have changed. Conversion must also involve a transformation of beliefs, feelings, ideas, and values. Further, if the process of conversion stops at a change in beliefs, ideas, feelings, values,

\footnotetext{
${ }^{5}$ Kraft, Worldview for Christian Witness, 11-31; see also Paul G. Hiebert, Transforming Worldviews: An Anthropological Understanding of How People Change (Grand Rapids, MI: Baker Academic, 2009).
} 
and behavior, and the underlying worldview is not transformed, in the long run converts will fall back into syncretism. ${ }^{6}$ This is why one of my respondents still believes that the dead are not dead and therefore continues to take part in traditional funeral rites. In the Christian experience, discipleship is a lifelong process and not merely an event that happens at or before baptism. This is why discipleship and mentoring are vital for the spiritual growth of converts.

\section{Inconsistency of Some Church Leaders}

It is possible for church leaders to cause other believers to stumble in their faith (Matt 18:6-7). Jesus' warning to his followers, "So you must be careful to do everything they [the teachers of the law and the Pharisees] tell you. But do not do what they do, for they do not practice what they preach" (Matt 23:3), also points to the likelihood of new converts being influenced by church leaders whose lives are inconsistent with church principles. The Lobi community members do not understand why some Adventists are seen at the forefront of funeral rituals while others refuse to be involved. Whenever any member refuses to take part in funeral rites, they are often reminded of the fact that some of their church leaders do not have any problem to do so. Some of my interviewees have been rebuked by their family members for refusing to take part in funeral rites on the ground that they were not better than other church members and leaders who did so. In the absence of the support of good role models in the church, some converts do not have any chance of withstanding societal pressure to conform to tradition.

\footnotetext{
${ }^{6}$ See Hiebert, Transforming Worldviews.
} 
For an effective mission and ministry in the traditional Lobi context, it is essential to address the above challenges to discipleship. The next chapter will focus on proposing a biblical and missiological framework for responding to the Lobi funeral rites. 


\section{CHAPTER 5}

\section{A BIBLICAL AND MISSIOLOGICAL FRAMEWORK FOR RESPONDING TO THE LOBI FUNERAL RITES}

\section{Introduction}

The biblical revelations were intended to reform or transform the beliefs, values, and practices of the peoples to whom they were first addressed as well as in subsequent generations who would choose to follow them. ${ }^{1}$ In real life situations, missionaries face many problems when it comes to issues dealing with the correlation between the gospel and human cultures. ${ }^{2}$ Throughout the history of Christian missions, one of the challenges has been how to be sensitive to different cultures and remain faithful to biblical principles at the same time. Unfortunately, sensitivity to local cultures has sometimes overshadowed faithfulness to biblical principles. Nevertheless, there is still a need to find ways of being both biblically faithful and culturally relevant in transmitting the principles of the Word of God. If we put emphasis only on biblical coherence, "we are in danger of being ineffective messengers at best, and at worst of communicating a gospel that is misunderstood and distorted." 3 In mission, we need to present the gospel in such a way

${ }^{1}$ Rick Brown, "Contextualization without Syncretism," International Journal of Frontier Mission 23, no. 3 (Fall 2006): 127.

${ }^{2}$ Hiebert, Anthropological Insights for Missionaries, 29.

${ }^{3}$ Ibid., 141. 
that if people reject it, it should not be because it is a misunderstood gospel. Terry Muck and Frances Adeney emphasize that the contextual complexity of many ministry and mission settings requires the use of different approaches instead of a one-size-fits-all approach. To them the biblical record shows that "every time the gospel engages a cultural setting it does so in a unique way."

The focus of this chapter is on developing a biblical and missiological framework with principles that could apply to studying any group of people in order to make the gospel presentation both biblically coherent and culturally relevant, thus minimizing the risk of religious syncretism.

\section{Critical Contextualization}

Contextualization has been defined in several ways over the decades. I find the following two definitions of contextualization to be the most comprehensive in relation to my study of the Lobi people group.

Michael Pocock, Gailyn Van Rheenen, and Douglas McConnell define contextualization as

the process whereby Christians adapt the forms, content, and praxis of the Christian faith so as to communicate it to the minds and hearts of people with other cultural backgrounds. The goals is to make the Christian faith as a whole-not only the message but also the means of living the faith out in the local settingunderstandable ${ }^{5}$ (emphasis in the original).

For David Hesselgrave and Edward Rommen, contextualization is the "attempt to communicate the message of the person, works, Word, and will of God in a way that is

\footnotetext{
${ }^{4}$ Terry Muck and Frances S. Adeney, Christianity Encountering World Religions: The Practice of Mission in the Twenty-First Century (Grand Rapids, MI: Baker Academic, 2009), 34.

${ }^{5}$ Michael Pocock, Gailyn Van Rheenen, and Douglas McConnell, The Changing Face of World Mission: Engaging Contemporary Issues and Trends (Grand Rapids, MI: Baker Academic, 2005), 323.
} 
faithful to God's revelation, especially as it is put forth in the teachings of Holy Scripture, and that is meaningful to respondents in their respective cultural and existential contexts. ${ }^{\circ 6}$ Contextualization is therefore a missional strategy concerned with finding appropriate means and methods of presenting the principles of the never-changing Word of God in the contexts of an ever-changing world in such a way that these principles are correctly understood by each context. As such, contextualization is not a one-time event but an ongoing process.

A number of reasons are given by scholars in favor of the practice of contextualization in mission and ministry. There are also arguments given to discredit the practice because of the risk of syncretism that might be associated with it. However, as stated by Dean Flemming and Paul Hiebert, contextualization is not an option in view of the fact that no single cultural expression of the gospel is ultimate, ${ }^{7}$ because "all cultures can adequately serve as vehicles for the communication of the gospel." ${ }^{\prime 8}$ It has been also argued that contextualization is part of God's missiology from the time of the fall, ${ }^{9}$ and that "properly understood, the Bible is a record of contextualized revelations; a record of the way God interacted with humans in space-time history in the totality of their contexts." 10

${ }^{6}$ David J. Hesselgrave and Edward Rommen, Contextualization: Meanings, Methods, and Models (Grand Rapids, MI: Baker Books, 1989), 200.

${ }^{7}$ Flemming, Contextualization in the New Testament, 138.

${ }^{8}$ Hiebert, Anthropological Insights for Missionaries, 55.

${ }^{9}$ Richard W. Engle, "Contextualization in Missions: A Biblical and Theological Appraisal," Grace Theological Journal 4, no. 1 (1983): 86.

${ }^{10}$ R. Musasiwa "Contextualization," Dictionary of Mission Theology, ed. John Corrie (Downers Grove, IL: InterVarsity Press, 2007), 67. See also Stephen B. Bevans, Models of Contextual Theology (Maryknoll, NY: Orbis Books, 2002). 
What is argued here is that although the message of Scripture is timeless, its interpretation and application is not. In other words, to interpret and apply the message of the Bible properly, we must not only seek to understand the context of the original hearers but also that of its contemporary audiences. Emphasizing the missiological and theological reality of contextualization, Stephen Bevans emphatically states that among fallen, limited human beings, "there is no such thing as ['pure'] theology; there is only contextual theology."11

In this section I briefly explore God's dealings with people in their cultural contexts in the Old and New Testaments. Insights gained from those sources will help to respond both biblically and missiologically to some of the challenges posed by the Lobi funeral rites to Christian missions.

\section{God and Cultural Context of the Old Testament}

God worked with the Israelites within the Ancient Near Eastern (ANE) cultural context. In order to lead them where he wanted them to be, God's revelation was embedded in the language and culture of ANE peoples. Andrew Hill and John Walton point out that in his interactions with the Israelites,

God also chose to accommodate aspects of his revelation to the cultural conventions of the ancient Near East. . . . An interesting illustration of this cultural conformity in divine revelation entails the laws protecting against a husband's jealousy for a woman suspected of adultery (Num. 5.11-31). In Mesopotamian laws, the accused party took an oath before the gods (e.g., the river god, Id) and then plunged (or was thrown) into the river. The gods would see that justice prevailed, determined by whether the defendant was spared (denoting innocence) or was caused to drown (denoting guilt). Although the procedure for the Hebrew "adultery test" was more enlightened than the

\footnotetext{
${ }^{11}$ Bevans, Models of Contextual Theology, 3.
} 
Mesopotamian river ordeal, it was still a male-dominated legal tradition in that the test was given only to a female. ${ }^{12}$

God also modified the ANE customs of blood vengeance, in which the near kinsman of the victim was obligated to avenge the death of his deceased relative by killing the manslayer. He instructed Moses and Joshua to establish cities of refuge for those guilty of the crimes of involuntary or accidental manslaughter (Num 35:9-28; Deut $4: 41-43 ; 19: 1-13 ;$ Josh 20). Hill and Walton comment that "the institution of the cities of refuge was unique in the ancient world and elevated Hebrew social and moral life to a higher plane than the surrounding nations." 13

Although God chose to reveal himself to Israel in the context of ANE culture, he also expressed his freedom to work outside the cultural norms of that time. God always legislated against existing practices that downplayed human dignity. An example of God overturning ANE customs in his dealings with Israel was his decision to give an inheritance in the promise land to Zelophehad's daughters (Num 27:1-11; 36:1-13). The custom of not giving shares to daughters in the family estate was apparently a standard practice among the Hebrews as well (Deut 27.15-17). Human sacrifice is another ANE religious practice that God prohibited the Israelites to partake in (Lev 18:21;20:2-5). A basic mission principle demonstrated in God's dealing with Israel in the ANE context is that in a cross-cultural setting, missionaries should be mindful of the fact that not all cultural practices are evil. Whatever is not against biblical principles should be

\footnotetext{
${ }^{12}$ Andrew E. Hill and John H. Walton, A Survey of the Old Testament (Grand Rapids, MI: Zondervan, 2009), 157-158.

${ }^{13}$ Ibid., 156-157.
} 
kept, some practices can be redeemed by modifying them, but anything against the teachings of Scripture should be discarded.

\section{Contextualization in the New Testament}

The early church was also faced with the dilemma of relating the gospel to local contexts. Under the leadership of the Holy Spirit they were able to transcend cultural boundaries in fulfilling the mandate to take the gospel to the ends of the world. Scholars see several examples in the New Testament as precedents to the practice of contextualization in contemporary mission. The following four are explored here: the incarnation of Christ as a foundation of contextualization, Logos in reference to Christ, four gospels instead of one, and the decisions of the Jerusalem Council.

\section{The Incarnation as a Foundation of Contextualization}

Richard Engel sees Christ's incarnation in the first century Jewish cultural setting as a perfect model of contextualization. He observes that Christ's incarnation as a human being serves as a foundation of "contextualization of God's message without compromise. By means of the incarnation God perfectly contextualized his communication (cf. Hebrews 1-2). He met his target culture where it was and as it was"14 (emphasis added). Alluding to Jesus' incarnation as a foundation of missiological contextualization, Gorden Doss argues that Christ's "life style would have been somewhat different had he been incarnated into another culture." 15 Finally, for Allan

\footnotetext{
${ }^{14}$ Engle, "Contextualization in Missions," 93.
}

${ }^{15}$ Gorden R. Doss, "The Jerusalem Council," in Adventist Responses to Cross-Cultural Mission: Global Mission Issues Committee Papers, vol. 2, 2002-2005, ed. Bruce L. Bauer (Berrien Springs, MI: Department of World Mission, 2007), 192. 
Neely, the prologue of John's Gospel, especially verses 1 and 14, is foundational for understanding the meaning and implications of contextualization. He asserts that the fuller context of John 1:1, 14 "suggests that in Jesus, God identified thoroughly with humankind, and that God came in Jesus for the express purpose of disclosing not only

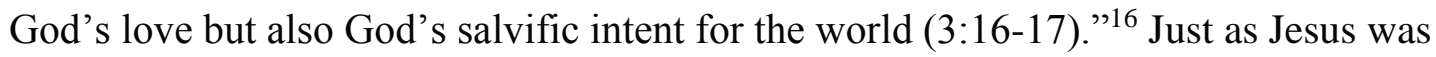
incarnated into human culture, so the Apostles applied the incarnational model to the teaching of his Gospel.

\section{Christ as the Logos in John 1:1, 14}

John begins his gospel by introducing Jesus as "the Word" (Logos). At the time of John, the word logos was loaded with different meanings. To the Jews, the logos "conveys the notion of divine self-expression or speech (cf. Ps. 19:1-4)"17 or an agent of creation (Ps 33:6). To Greek philosophers, the logos was the principle of reason that ruled the world. ${ }^{18}$ With these different understandings, it was unthinkable for Greeks to say that "the Logos became flesh," (John 1:14) because for them "the separation of the divine spirit and the mundane world (flesh, sarx) was an axiom of belief." ${ }^{19}$ For that reason, to say that Jesus took on flesh was to suggest an image of lowliness. ${ }^{20}$ For Jews it was

\footnotetext{
${ }^{16}$ Alan Neely, “Incarnational Mission,” Evangelical Dictionary of World Mission, ed. A. Scott Moreau (Grand Rapids, MI: Baker Books, 2000), 474.

${ }^{17}$ Andreas J. Köstenberger, John (Grand Rapids, MI: Baker Academic, 2004), 25.

${ }^{18}$ Charles L. Campbell, “John 1:1-14,” Interpretation 49, no. 4 (October 1995): 395. See also B. E. Reynolds, "Logos" in Dictionary of Jesus and the Gospels, ed. Joel B. Green (Downers Grove, IL: IVP Academic, 2013), 523-526. 59.

${ }^{19}$ Gary M. Burge, John, The NIV Application Commentary (Grand Rapids, MI: Zondervan, 2000),

${ }^{20}$ G. L. Parsenios, “Incarnation," Dictionary of Jesus and the Gospels, ed. Joel B. Green (Downers Grove, IL: IVP Academic, 2013), 400.
} 
blasphemous to state that "the Logos was God," (John 1:1) i.e., inferring "some personal identity between the Logos and God."21 It was also shocking for Jews to hear that the Logos became flesh and made his dwelling among human beings because "the verb for dwelling is employed in the Greek Old Testament for the tabernacle of God. In other words, Christ is the locus of God's dwelling with Israel as he had dwelt with them in the tabernacle in the desert (Ex. 25:8-9; Zech. 2:10). Hence the glory of God, once restricted to the tabernacle (Ex. 40:34), is now visible in Christ (John 1:14b)." 22

In this religiously pluralistic context it was a risky creativity for John to introduce Jesus as Logos to his audience (both Jews and Gentiles) since each group would be inclined to understand it from their cultural perspective. For John however, "the different understandings proved to be the key to begin a creative dialogue with his context and explain the Jesus tradition through this dialogue. ${ }^{, 23}$ In this dialogue, John leads his audience to understand the Logos not only as a divine creative attribute or as a simple principle of order in the universe, but as a full divine being alongside God. John's strategy demonstrates the necessity of using cultural concepts, for example, names for God, but infusing them with biblical meaning over time in order to make the proclamation of the gospel contextual, effective, and meaningful. For Andreas Köstenberger, in John 1:1-18, John does contextualization by employing universal terms such as "word" and "light" to engage adherents of religions and worldviews in his

\footnotetext{
${ }^{21}$ Burge, John, 54.

${ }^{22}$ Ibid., 59.

${ }^{23}$ D. R. Sadananda, "The Johannine Logos: Interpreting Jesus in a Multi-Religious Context," in Reformed Theology, ed. Wallace M. Alston Jr. and Michael Welker (Grand Rapids, MI: William B. Eerdmans, 2007), 367.
} 
religiously pluralistic context. ${ }^{24}$ A missional principle derived from this precedent is that the presentation of the timeless message of Scripture must be done "by using the cultural

forms, words, and symbols of a people in order to better present that timeless message." 25

\section{The Gospels}

Why did four biblical authors take it upon themselves to tell the story of Jesus?

Flemming answers this question by pointing out that

If modern Gospel studies have taught us anything, it is that the four Evangelists have narrated the story of Jesus according to their own theological and literary concerns and in light of how they perceived the needs of their readers. We might even say that the four Gospels are 'four contextualizations' of the one story. The Gospels, then, form an important piece of the total picture of how the Christian message is reexpressed for new audiences in the New Testament. ${ }^{26}$ (emphasis added)

The same story was packaged by each author in a different way for the consumption of a specific audience.

\section{The Jerusalem Council-Acts 15}

By the time of Acts 15, many Gentiles had come to faith in Christ. Their conversion to Christianity raised some fundamental theological questions. According to the account of Acts 15, one of the issues the early church struggled with was how to admit Gentile believers into full church membership. Was circumcision to be part of the terms on which Gentile converts were to be admitted? After a lengthy discussion they agreed that the Jewish "cultural specificities need not cross over the cultural bridge to the

\footnotetext{
${ }^{24}$ Köstenberger, John, 31.

${ }^{25}$ Bruce L. Bauer, “Avoiding Comfortable Syncretism by Doing Critical Contextualization,” in Adventist Responses to Cross-Cultural Mission: Global Mission Issues Committee Papers, vol. 2 (Berrien Springs, MI: Department of World Mission, 2007), 246.

${ }^{26}$ Flemming, Contextualization in the New Testament, 234.
} 
Gentiles." ${ }^{27}$ Later Paul wrote that "circumcision is nothing and uncircumcision is nothing. Keeping God's commands is what counts" (1 Cor 7:19). Although the council refrained from asking Gentile believers to be circumcised and adopt a Jewish way of life as a prerequisite to full church membership, they were however required "to abstain from food sacrificed to idols, from blood, from the meat of strangled animals and from sexual immorality" (Acts 15:29). Gentiles were allowed to live by their own cultural norms as long as those norms were not in conflicts with core biblical teachings.

The early church thus chose cultural diversity over cultural uniformity in faith expression. As a result of this agreement, "church life for Greek disciples was different from church life for Jewish disciples," and "the cultural differences that exist[ed] between Jewish believers and other believers no longer formed a barrier preventing fellowship between them." ${ }^{28}$ A fundamental principle of the Jerusalem Council's proceedings is that in our cross-cultural missionary endeavors, we always need to distinguish between our cultural baggage and biblical principles.

\section{Process of Critical Contextualization}

"Critical Contextualization" is a term coined by Paul Hiebert in his attempt to answer the following question: "What should people do with their old cultural ways when they become Christians, and how should the missionary respond to these traditional beliefs and practices?"29 In doing critical contextualization, "old beliefs and customs are

\footnotetext{
${ }^{27}$ Gorden Doss, “The Jerusalem Council,” 195.

${ }^{28}$ Brown, "Contextualization without Syncretism," 128.

${ }^{29}$ Hiebert, Anthropological Insights for Missionaries, 171.
} 
neither rejected nor accepted without examination. They are first studied with regard to the meanings and places they have within their cultural setting and then evaluated in the light of biblical norms." 30

The recognition by a local congregation of the need to deal biblically with certain aspects of their lives is the prerequisite to doing critical contextualization. Critical contextualization is done following four main steps as outlined by Hiebert: exegesis of culture, exegesis of Scripture, critical response, and functional substitutes. ${ }^{31}$ The members of the local congregation directly affected by a change should be actively involved in the whole process because of their knowledge of the deeper and hidden meanings associated with their cultural practices. This is the reason critical contextualization should never be attempted in solo by a pastor/missionary on behalf of a local congregation.

\section{Exegesis of Culture}

The exegesis of culture is done by uncritically gathering, describing, and analyzing all available information on specific cultural practices such as songs, gestures, dance, etc. The purpose of this first step is to understand the cultural practices being examined, not to evaluate or disapprove them. Any criticism of these cultural practices will prevent the people concerned from openly talking about them for fear of being condemned.

\footnotetext{
${ }^{30}$ Hiebert, Anthropological Insights for Missionaries, 186.

${ }^{31}$ Ibid., 186-190.
} 


\section{Exegesis of Scripture}

The exegesis of the Scriptures is undertaken to understand the biblical teachings about the cultural practice under consideration. In this step, the local congregation is led in Bible studies in relation to the question at hand. This step is vital because if the local congregation does not clearly apprehend and accept the biblical teaching related to their cultural practice, they will not be able to effectively deal with any unbiblical elements associated with it.

\section{Critical Response}

At this stage of the process, the local congregation critically evaluates their cultural practices in the light of biblical teachings and makes a decision regarding what to do about them. In most cases, cultural practices will be kept if there are no unbiblical elements present. They can also be modified to infuse them with explicit Christian meanings, or simply rejected if they prove to be unbiblical. Once again, it is important that the pastor/missionary avoids making the final decision for the congregation. If he/she does so, the congregation is likely to give a public consent to the decision but continue to practice them in secret. If the local congregation makes the decision to reject the unbiblical elements in their cultural practices, they would then be much more likely to ensure corporately that the decision arrived at is enforced.

\section{Functional Substitutes}

The last step in the process of critical contextualization is concerned with creating a contextualized Christian form of the unbiblical cultural practice. This may involve creating new symbols and rituals to communicate biblical principles in forms understandable to the local context. 


\section{Transformational Ministry}

Because change often tends to be short-lived due to the natural tendency to slip back to the status quo, ${ }^{32}$ another step, transformational ministry, is needed in addition to Hiebert's four steps to enable the local congregation to successfully manage its transition to the new state. In this step, the missionary/pastor functions as a mentor to gently and constantly remind and encourage the congregation to apply the decisions corporately arrived at through the process of critical contextualization. This may involve attending funeral ceremonies and studying the Bible together as a way of encouraging one another to stand firm on biblical principles. Although this step will take time, it is indispensable to allow the changes decided on to become permanent. Because critical contextualization is an ongoing process, there also needs to be a constant evaluation of the actions taken by the congregation.

\section{Minimizing the Risk of Religious Syncretism in Mission}

Religious syncretism is frequently mentioned in the Bible. In many ways the Ten Commandments are God's instructions against religious syncretism because the first three commands (Exod 20:1-7) charge the Israelites "to distinctively stand before God without reliance on any other gods. ${ }^{, 33}$ Just as the Israelites were warned against rejecting Yahweh and serving other gods (Deut 11:16; 2 Kgs 10:23), so too were New Testament Christians warned against dual allegiance and syncretism (Matt 6:24; 1 Cor 10:14; Rev 22:15).

\footnotetext{
${ }^{32}$ Lyle E. Schaller, The Change Agent: The Strategy of Innovative Leadership (Nashville, TN: Abingdon Press, 1972), 86.

${ }^{33}$ Gailyn Van Rheenen, "Modern and Postmodern Syncretism in Theology and Mission," in The Holy Spirit and Mission Dynamics, ed. C. Douglas McConnell (Pasadena, CA: William Carey, 1997), 173.
} 
Syncretism is a worldwide religious challenge. According to Michael Pocock, "all peoples and religions exhibit syncretism" ${ }^{\prime 34}$ (emphasis added). Unfortunately, when the influence of syncretism in the church is discussed, many tend to see it happening outside Western Christianity as if the Western form of Christianity is immune to syncretism. But Andrew Walls and Scott Moreau argue respectively that "syncretism is a greater peril for Western than African or Indian Christians, and less often recognizable for what it is." 35 They also point out that "syncretism of some form has been seen everywhere the church has existed. ${ }^{36}$ In other words, syncretism is a threat found among Christians universally as they express their faith either within their own cultures or cross-culturally. One might debate whether or not Western Christianity is inherently in greater peril of syncretism. This may be so because for centuries Western Christianity's historic role as the dominant form of Christianity has bestowed on it a seal of orthodoxy that is too often unchallenged; forgetting that the West's slide into secularism can be seen as a form of syncretism.

This section discusses three major factors contributing to religious syncretism and then offers a biblical and missiological response to the threat in contextualizing the gospel in the Lobi context.

\footnotetext{
${ }^{34}$ Michael Pocock, "Introduction: An Appeal for Balance," in Missiology and the Social Sciences: Contributions, Cautions and Conclusions, ed. Edward Rommen and Gary Corwin (Pasadena, CA: William Carey, 1996), 10.

${ }^{35}$ Andrew F. Wall, The Cross-Cultural Process in Christian History (Maryknoll, NY: Orbis Books, 2002), 69.

${ }^{36}$ A. Scott Moreau, "Syncretism," in Evangelical Dictionary of World Mission (Grand Rapids, MI: Baker Books, 2000), 924.
} 


\section{Understanding Religious Syncretism}

Scrutinizing literature on religion and missions reveals definitions of syncretism with subtle differences. Synthesizing some of these definitions of syncretism is the focus of this section. André Droogers and Sidney Greenfield offer a brief but succinct history of syncretism. They point out that the term

"syncretism" was first used by Plutarch to describe the temporary coming together of the quarreling inhabitants of Crete in the face of a common enemy. . . . The Greek word from which the English "syncretism" is derived refers to people joining together, in this case in battle. Erasmus later employed it metaphorically to refer to an agreement between people with seemingly disparate opinions. The new reference centered on ideas and beliefs. Seventeenth-century theologians then gave it a negative connotation by using it for what to them was the undesirable reconciliation of Christian theological differences. Syncretism for them became a threat to "true" religion. To this negative judgment a more neutral view was added in the second half of the nineteenth century when students of the history of religions began to use the word to acknowledge the mixing of religious elements from diverse sources, including Christianity that had occurred and continues to take place. ${ }^{37}$

Religious syncretism is generally defined today as the blending of different (sometimes contradictory) forms of religious beliefs and practices. Gailyn Van Rheenen defines syncretism as "the reshaping of Christian beliefs and practices through cultural accommodation so that they consciously or unconsciously blend with those of the dominant culture... Syncretism is the blending of Christian beliefs and practices with those of the dominant culture so that Christianity [drops its distinct nature and] speaks with a voice reflective of its culture"38 (emphasis in the original). For Lynn D. Shmidt, "A person who draws from two or more belief systems at the same time is guilty of

\footnotetext{
${ }^{37}$ André Droogers and Sidney M. Greenfield, "Recovering and Reconstructing Syncretism," in Reinventing Religions: Syncretism and Transformation in Africa and the Americas, ed. Sidney M. Greenfield and André Droogers (New York: Rowman and Littlefield, 2001), 27-28.

${ }^{38}$ Van Rheenen, "Modern and Postmodern Syncretism in Theology and Mission,” 173.
} 
syncretism. He or she is reaching for the best of two religious worlds." 39 While in Van Rheenen's definition it is possible for a church as a whole to succumb to syncretism through cultural accommodation in its effort to be relevant to the culture in which it bears witness, in Shmidt's definition it is individual believers who are to be blamed for drawing from non-Christian belief systems.

In the Dictionary of Asian Christianity, Mark Mullins addresses the difference between standard usages of "syncretism" in the social sciences and in missiology. He points out that the term

"syncretism" is usually understood as a combination of elements from two or more religious traditions, ideologies, or value systems. In the social sciences, this is a neutral and objective term that is used to describe the mixing of religions as a result of culture contact. In theological and missiological circles, however, it is generally used as a pejorative term to designate movements that are regarded as heretical or sub-Christian. ${ }^{40}$

In his definition of syncretism, Mullins points out that it is not everyone that sees syncretism as a negative phenomenon, and in agreement with Van Rheenen he sees contact with a new culture as one of the possible contributing factors of religious syncretism.

In the Evangelical Dictionary of World Missions, Scott Moreau presents a more nuanced definition of syncretism. He defines syncretism as the

blending of one idea, practice, or attitude with another. Traditionally among Christians it has been used of the replacement or dilution of the essential truths of the gospel through the incorporation of non-Christian elements. . . Syncretism of some

\footnotetext{
${ }^{39}$ Lynn D. Shmidt, “How Much Syncretism Is Allowed?” Evangelical Missions Quarterly (January 2013): 27-28.

${ }^{40}$ Mark R. Mullins, "Syncretistic Movements," in Dictionary of Asian Christianity, ed. Scott W. Sunquist (Grand Rapids, MI: William B. Eerdmans, 2001), 809-810.
} 
form has been everywhere the church has existed. We are naïve to think that eliminating the negatives of syncretism is easily accomplished. ${ }^{41}$

Throughout the rest of this discussion, religious syncretism refers to the blending of non-biblical elements from another tradition into the beliefs and practices of Christianity.

\section{Factors Contributing to Religious Syncretism}

Several factors are known to contribute to religious syncretism. Three of these factors are discussed here: the growing acceptance of religious pluralism, mission approaches to other religions, and inadequate discipling of new converts.

\section{Growing Acceptance of Religious Pluralism}

That the world has become a religiously plural place is a fact that cannot be denied. People of diverse ethnic origins and many dissimilar religious commitments live and share public life together. This globalization has put major world religions within the reach of almost everyone today. Worldwide migration patterns, international travel and trade, progress in communications technology, and international media activities have introduced people to nearly all religious traditions. Mission is no longer from the West alone; Islam and Eastern religions are also dynamically engaged in missionary work. ${ }^{42}$ This has resulted in the option of cafeteria-style choices in the area of religion with many people picking and choosing from among various religious traditions and practices to

\footnotetext{
41 "Syncretism," in Evangelical Dictionary of World Missions, ed. A. Scott Moreau (Grand Rapids, MI: Baker Books, 2000), 924-925.

${ }^{42}$ Roger E. Hedlund, "Religious Pluralism: Fact and Issue," in Many Other Ways? Questions of Religious Pluralism, ed. M. Bage, R. Hedlund, P. B. Thomas, Martin Alphonse, and George David (New Delhi, India: Printsman, 1992), 13.
} 
meet their personal needs. ${ }^{43}$ If all religions are equally valid ways to salvation as some argue ${ }^{44}$ then a cocktail of religious beliefs and practices is even better. As a result of this religious globalization, religious traditions outside of Christianity and Judaism are no longer treated as "the work of the Devil." Modern scholarship not only promotes many positive features of other religions, it also claims that "all religions, including Christianity, are relative. . . [ [and that] every religion is considered equally valid." ${ }^{45}$ Religious pluralism is thus built on the assumption that the different religious traditions are complementary rather than contradictory. As a direct result of this call for cooperation among various religious cultures, there is a growing positive public attitude to other religions. Religious pluralism, especially in the West, seems to have become a spiritual adventure ${ }^{46}$ to the extent that Claude Geffré even affirms that "the religiosity of the Western person of our times is spontaneously syncretistic." ${ }^{47}$ Pressure for syncretism comes from two directions: from non-Christian religions and from within Christianity itself. When Christian thinkers also advocate a pluralistic theology of religions, thus $2011,20$.

${ }^{43}$ Amy Frykholm, “One Person, Two Faiths: Double Belonging,” Christian Century, January 25,

${ }^{44}$ P. B. Thomas, “Any Other Name? A Response to Dialogical Theology,” in Many Other Ways? Questions of Religious Pluralism, ed. M. Bage, R. Hedlund, P. B. Thomas, Martin Alphonse, and George David (New Delhi, India: Printsman, 1992), 28.

${ }^{45}$ Ibid.

${ }^{46}$ Yossi K. Halevi, At the Entrance to the Garden of Eden: A Jew's Search for Hope with Christians and Muslims in the Holy Land (New York: Harper Perennial, 2002), 9.

${ }^{47}$ Claude Geffré, "Double Belonging and the Originality of Christianity as a Religion," in Many Mansions? Multiple Religious Belonging and Christian Identity, ed. Catherine Cornille (Maryknoll, NY: Orbis Books, 2002), 94. 
asserting the subjectivity of Christian belief statements, the Church cannot but be under the threat of religious syncretism. ${ }^{48}$

\section{Mission Approaches to Other Religions and Cultures}

Christian mission to other religions and cultures has sometimes gone to two opposing extremes. One extreme consists of the denial "that there is anything that is of God in non-Christian religions." 49 The other extreme is that in some contexts, both crossculturally and intra-culturally, Christian mission has indiscriminately accommodated local cultures and religions. ${ }^{50}$ Both of these approaches-displacement and accommodation - have negative effects on the types of Christianity they produce.

The indiscriminate rejection of old religious practices either creates a void that is filled by imported practices leading to the gospel being misunderstood and rejected, or the old religious practices simply go underground. ${ }^{51}$ Whenever old religious practices go underground, believers assent to orthodox Christian beliefs and join in the public denunciations of their old religious forms, but privately retain their loyalty to them especially in times of serious crises. ${ }^{52}$ This reversion to old religious practices is a direct result of the displacement model's exclusive focus on doctrinal and rational arguments in

\footnotetext{
${ }^{48}$ Thomas, “Any Other Name?” 28.

${ }^{49}$ Jabulani A. Nxumalo, "Christ and Ancestors in the African World: A Pastoral Consideration," JTSA no. 32 (September 1980): 6.

${ }^{50}$ Hiebert, Anthropological Insights for Missionaries, 185.

${ }^{51}$ Ibid., 184, 188.

${ }^{52}$ Partain, "Christians and their Ancestors," 1067.
} 
contexts where existential issues rather than clarity and orthodoxy are the most important considerations. $^{53}$

The accommodation paradigm tends towards an uncritical acceptance of traditional practices by the church because they are thought to be part of a people's cultural heritage that is cherished. ${ }^{54}$ However, these traditional practices often contain syncretistic nonbiblical elements from the receptor culture. ${ }^{55}$ This happens both in cross-cultural and intra-cultural missions. Van Rheenen sees the root cause of syncretism here in the fact that the church too often accommodates to the worldviews of its time. For him,

syncretism frequently begins apologetically: The Christian community attempts to make its message and life attractive, alluring, and appealing to those outside the fellowship. Over a period of years the accommodations become routinized, integrated into the narrative story of the Christian community and inseparable from its life. ... Syncretism thus occurs when Christianity opts into the major cultural assumptions of its society. ${ }^{56}$

As such, the accommodation model indirectly minimizes change in the lives of converts whereas the gospel challenges people individually and corporately to turn from their unbiblical practices. This paradigm thus opens the door to syncretism as Christians continue to maintain beliefs and practices that stand in conflict with the gospel.

In view of the above, both accommodation and displacement as mission approaches to other religions and cultures potentially promote religious syncretism.

\footnotetext{
${ }^{53}$ Klaus Nürnberger, "Ancestor Veneration in the Church of Christ?" Journal of Theology for Southern Africa no. 129 (November 2007): 66.

${ }^{54}$ Mary Yeo Carpenter, "Familism and Ancestor Veneration: A Look at Chinese Funeral Rites," Missiology: An International Review 24, no. 4 (October 1996): 504.

${ }^{55}$ David J. Hesselgrave and Edward Rommen, Contextualization: Meanings, Methods, and Models (Pasadena, CA: William Carey, 2000), 1.

${ }^{56}$ Van Rheenen, "Modern and Postmodern Syncretism in Theology and Mission,” 173.
} 


\section{Inadequate Discipling of New Converts}

Some converts to Christianity revert to their previous religious practices or reach out to new non-Christian practices in times of crises. This reversal sometimes comes as the result of an inadequate discipling process before and after their acceptance into church membership. Because of this faulty discipleship process, converts do not experience completeness in Christ that is both culturally appropriate and biblically faithful. As such, it becomes difficult for them to continue to stand firm on Christian principles especially if some of their pressing needs are not yet met.

The use of a baptismal model of mission rather than a discipleship model is another cause of religious syncretism. In the baptismal model, success is seen to have been achieved upon baptism. In the discipleship model, baptism is an early part of a long and continuing process. In a baptismal model of mission, much discipleship is hasty and incomplete. Many of those who show interest in becoming Christians are taught and then baptized; the event of baptism often marks the end of the discipleship process for some of them. Once in full church membership, some converts are no longer shown the same degree of personal attention the church gave them prior to their baptism. It is implicitly assumed that the rest of the process will be taken care of by weekly sermons and prayer meetings. Unfortunately the sharing of Christian principles in Sabbath sermons or during the mid-week prayer meetings usually does not effectively address the deep issues some of the converts are struggling with.

Discipleship is not synonymous with simply presenting biblical truth no matter how crucial that truth is. The process of discipleship involves more than just an information transfer about doctrinal correctness. It requires a personal relational 
investment in the learner by one or more mature Christians that allows for molding, mentoring, counsel, and conversational instruction over a significant period of time.

\section{A Biblical Response to Religious Syncretism}

\section{Emphasis on Discipleship}

The threat posed by syncretism is not so much with the converts' old religious beliefs and practices as it is with the underlying assumptions on which these old beliefs are built. People will not give up on their old beliefs so long as those old beliefs remain the only working alternatives they have. ${ }^{57}$ The only solution is for the gospel to not only change former beliefs but also to transform the converts' worldviews. If this does not happen the new beliefs will continue to be reinterpreted in terms of the old worldviews. ${ }^{58}$ A biblical model of discipleship is key to worldview transformation.

A good biblical model of discipleship is portrayed in 1 Thess 2:7-13. This text presents discipleship as a process of spiritual parenting. In that passage Paul uses the parent-child metaphor to describe principles of discipleship by referring to familiar things of life which both the direct recipients and the wider readership of the epistle were conversant with. This parent-child metaphor is still a powerful means of impressing on people’s minds important spiritual principles about Christian discipleship. A brief analysis of this passage reveals the following four components of biblical discipleship.

\footnotetext{
${ }^{57}$ Ellen Van Velsor and Wilfred H. Drath, “A Lifelong Developmental Perspective on Leader Development," in Handbook of Leadership Development, 2nd ed., ed. Cynthia D. McCauley and Ellen Van Velsor (San Francisco, CA: Jossey-Bass, 2004), 390.

${ }^{58}$ Paul G. Hiebert, R. Daniel Shaw, and Tite Tiénou, "Responding to Split-Level Christianity and Folk Religion," IJFM 16, no. 4 (Winter 1999/2000): 177.
} 
Long-term commitment to the spiritual welfare and growth of believers. "Just as a nursing mother cares for her children, so we cared for you" (vv. 7 and 8, emphasis added). Paul and his missionary team cared for the believers in the congregations they established as a mother cares for her children. This would have involved tenderly and patiently teaching the Thessalonians to walk with God. They demonstrated intentional commitment to the spiritual growth and welfare of believers.

Modeling a spiritual walk with God. "Surely you remember, brothers and sisters, our toil and hardship; we worked night and day in order not to be a burden to anyone while we preached the gospel of God to you. You are witnesses, and so is God, of how holy, righteous and blameless we were among you who believed" (vv. 9 and 10, emphasis added). The missionary team strove to be role models to the new believers. If Hampton Keathley's perspective on discipleship is correct, about 90 percent of what a disciple learns or applies is caught from the discipler's life rather than from his/her teaching. As a result, he argues that "we should place our emphasis on being a friend and let people see how we deal with things, how we study, how we pray, how we love, etc. We don't want to just give him all the facts. We need to allow him to see how we work through various issues and help him work through the issues himself." ${ }^{\text {59 }}$ Without any doubt, this was what happened in Jesus' discipling ministry of the Twelve and his other early followers who so faithfully imitated him that when those who had observed them found no other way to call them but Christians (Acts 11:26).

\footnotetext{
${ }^{59}$ Hampton Keathley IV, “Discipleship Overview," Bible.org, accessed November 22, 2014, www.http://bible.org/article/ discipleship-overview.
} 
Personal attention to believers' spiritual needs. "For you know that we dealt with each of you as a father deals with his own children, encouraging, comforting and urging you to live lives worthy of God, who calls you into his kingdom and glory" (vv. 11 and 12, emphasis added). They gave believers individual attention and instruction as a father would do to his children with the intention to help each of them with unique needs. They understood that each believer's uniqueness meant individual attention. Hampton Keathley illustrates this need for personal attention as follows.

When we bring a newborn home from the hospital, we don't just put down the infant and say, "Welcome to the family, Johnny. Make yourself at home. The towels are in the hall closet upstairs, the pantry is right here, the can opener is in this drawer. No crying after $10 \mathrm{p} . \mathrm{m}$. If you have any questions there are lots of people in the family who would love to help you so don't be afraid to ask." You laugh and say that is ridiculous, but that is what usually happens to new Christians. Someone gets saved and starts going to church but never gets much personal attention. We devote 18 years to raising our children, but don't even spend six months helping a new Christian get started in understanding the spiritual world. As a result, many people have been Christians for many years, but have not grown very much. Hebrew 5:12 refers to this phenomenon. So, new believers need someone to give them guidance and help them grow. Like a newborn, they need some personal attention. ${ }^{60}$

Another important insight highlighted in Keathley's illustration is that discipling converts requires a significant investment of time. It is not an event limited to a two to three week evangelistic series or something that is taken care of in a formal teaching setting (e.g., baptismal class). This makes mentorship inseparable from discipleship. Beside the formal teaching settings, spiritual mentors should be available to share their spiritual journey and experiences (both positive and negative) with new converts.

The teaching of biblical truth. "And we also thank God continually because, when you received the word of God, which you heard from us, you accepted it not as a

\footnotetext{
${ }^{60}$ Keathley, "Discipleship Overview."
} 
human word, but as it actually is, the word of God, which is indeed at work in you who believe" (v. 13). Conforming themselves to the command of Matt 28:19-20, Paul and his companions made the Word of God an essential element of the Thessalonians' discipleship process.

The passage in 1 Thess 2:7-13 clearly shows that although the teaching of biblical truth was essential, it was not the sole component of Paul's missionary team's discipleship model. While the teaching of biblical truth is an essential component of discipleship because a convert cannot fully mature spiritually without understanding biblical principles, it must also be acknowledged that a convert may have considerable biblical knowledge and yet remain spiritually immature. For this reason the teaching of biblical truth must always be balanced with other components of biblical discipleship such as an intentional commitment to the spiritual growth and welfare of new believers, a modeling of a spiritual walk with God, and personal attention to each believer's spiritual welfare and growth needs. Congregational and small group teaching and personal attention of the believers are needed to encourage them along the road to their Christian maturity. Just as a baby needs an additional amount of attention, new converts also need someone to provide them with attention and guidance in the maturation process.

\section{Dimensions of Biblical Discipleship}

Christian witness and discipleship are associated with truth, allegiance, and power dimensions. Each of these three dimensions has its specific concern. The concern of the truth dimension is to counter ignorance or error in order to bring people to a correct understanding about Jesus Christ. The concern of the allegiance dimension is to bring people to undivided commitment and growing obedience to God. The power dimension, 
sometimes referred to as spiritual warfare or the Great Controversy, is concerned with releasing people from Satan's captivity and bringing them to freedom in Jesus Christ. ${ }^{61}$ Although each of these three dimensions has its specific concern, all three need to be interrelated for wholistic spiritual growth.

Truth and allegiance dimensions have generally been emphasized more than the power dimension in Christian witness. This approach to spiritual growth thus seems to show preference to these two dimensions instead of stressing that all three are necessary for holistic Christian maturity. Too often little if any attention is paid to the power dimension as if Christian discipleship rests only on the truth and allegiance one confesses. Such a strategy does great damage by neglecting an essential pillar-poweron which Christian discipleship must also rest. By neglecting the power dimension, the focus is on cognitive knowledge about God and some aspects of the Christian life without any tangible experience of these aspects in everyday life. ${ }^{62}$

The purpose of this section is to point to the need for a move from an unbalanced emphasis on cognitive belief to a balanced use of all three dimensions in Christian witness and discipleship.

Truth dimension. The truth dimension has to do with cognitive understanding of biblical truth. Before surrendering their lives to Christ, people need a certain level of understanding of scriptural truth. Jesus spent an important part of his ministry in the

\footnotetext{
${ }^{61}$ Charles Kraft, "Three Encounters in Christian Witness," in Perspectives on the World Christian Movement, 4th ed., ed. Ralph D. Winter and Steven C. Hawthorne (Pasadena, CA: Institute of International Studies, 2009), 446.

${ }^{62}$ Charles H. Kraft, "Contextualization in Three Crucial Dimensions," in Appropriate Christianity, ed. Charles H. Kraft (Pasadena, CA: William Carey, 2005), 102.
} 
teaching of truth (e.g., the Sermon on the Mount in Matt 5-7; the parables: Luke 15;

18:1-14; 19:11-26; Matt 11:1; Luke 4:31-32; John 15:1-17). His intention was for his hearers to grow in their understanding of the person and will of God in order for them to have a better relationship with him. However, he focused more on knowledge grounded in relationship and experience with God than on head knowledge alone (John 8:32;

15:1-10). In John 4:23, Jesus couples the cognitive and experiential dimensions of truth as the formula for the identity of true worshippers by stating that "Yet a time is coming and has now come when the true worshipers will worship the Father in the Spirit and in truth, for they are the kind of worshipers the Father seeks" (emphasis added).

Although Pentecostals tend to lay the emphasis on power, truth is the dimension usually emphasized among Seventh-day Adventists. Unlike Jesus, Christian witness tends to focus heavily on cognitive knowledge assuming that people who hear about the various aspects of the Christian life will have sufficient reasons to convert to Christ. Unfortunately, there is no automatic transfer from knowledge about Christian beliefs and lifestyle to the actual experience of these aspects of Christianity. The cognitive and informational dimensions of truth, although necessary, are often strongly emphasized to the detriment of relational and experiential truth. In most cases, people's minds are filled with pieces of information thus leading to "an intellectual understanding of Christianity,"63 and thereby forgetting that "whenever the Scripture speaks of knowledge and truth, it is referring to experiential knowledge and truth, not merely the intellectual

\footnotetext{
${ }^{63}$ John Wimber and Kevin Springer, Power Evangelism (Ventura, CA: Regal, 2009), 187.
} 
byproducts of these factors" ${ }^{\prime 4}$ (emphasis in the original). A related problem is that when Christian witness focuses primarily on fighting error by pointing out truth, it often pays little attention to discipleship and mentoring. Also, with the rigorous intellectual task of Bible study very often employed by the truth dimension, students of the Bible can easily fall "into reliance on study rather than reliance on the Holy Spirit." ${ }^{\prime 55}$ As a result, converts are not taught how to apply their intellectual knowledge to their day-to-day challenges.

Allegiance dimension. Many biblical teachings are primarily concerned with the believer's relationship to God. Throughout the Scriptures, God constantly calls people to commit themselves to him as their primary allegiance. The relationship dimension of discipleship is thus focused on growing in an intimate relationship with God. Hearing and accepting the truth cognitively as it is in the Bible is not the end of the Christian experience. After consenting to the truth that the Bible teaches, converts need to constantly pay close attention to their experiential growth in Christ (2 Pet 3:18). One of the dangers in spiritual growth is making truth and faith something that is merely discussed rather than something that moves us into allegiance to Christ. Although the goal of the Great Commission (Matt 28:18-20) is to make disciples by teaching them to obey the truth as it is presented in Scripture, disciples are made only when converts pledge full allegiance (commitment and obedience) to Christ and continue to do so every day of their lives. In contrast, members too often are people who have made an intellectual assent to a body of truth and who have been baptized without any further

\footnotetext{
${ }^{64}$ Kraft, "Contextualization in Three Crucial Dimensions," 107.

${ }^{65}$ Wimber and Springer, Power Evangelism, 187.
} 
follow up toward full commitment to the lordship of Christ. Ellen G. White insists that unless believers choose only the disposition of Christ, that is, unless Christ's interests are identified with theirs, they are not fit to be called disciples. ${ }^{66}$ For that reason, the allegiance dimension is a vital piece of Christian experience; for without this continual commitment and obedience to Christ, there is no spiritual life.

Loyalty to Christ is a lifelong process that starts at conversion and moves the convert into a more intimate relationship with Christ and other believers. The goal of this process is to grow in the likeness of Christ. As this happens, the new and growing relationship with Christ replaces any other commitment that was primary in the convert's life before he/she met Christ. This is evident in Christ's call to make him first in everything. He is radical in his call to discipleship, "If anyone comes to me and does not hate [love me more than] father and mother, wife and children, brothers and sisters-yes, even their own life — such a person cannot be my disciple” (Luke 14:26). Charles Kraft expresses well the uniqueness and the importance of the allegiance dimension of the Christian life in comparison to its truth and power dimensions by pointing out that

The allegiance-relationship dimension is quite distinct from the other two dimensions. For example, no one becomes a Christian simply through knowledge or power. As James says, even demons have enough understanding to cause them to tremble in fear (Jas. 2:19). They have all the knowledge they need but none of the relationship required for salvation. Yet we are often taught to witness primarily by increasing the person's knowledge, as if knowledge is going to bring him/her into the Kingdom. ... We can't simply click into a relationship on the basis of what we know. ${ }^{67}$

\footnotetext{
${ }^{66}$ Ellen G. White, Selected Messages Book 1 (Washington, DC: Review and Herald, 1958), 110.

${ }^{67}$ Kraft, “Contextualization in Three Crucial Dimensions," 105.
} 
Power dimension ${ }^{68}$ The Bible contains a series of divine power manifestations. Two of the prominent Old Testament power demonstrations are found in Exod 5-12 (Moses and Pharaoh) and in $1 \mathrm{Kgs} 18$ (Elijah and the prophets of Baal). Jesus' ministry also included power demonstrations in order to challenge and defeat the powers of Satan. In fact, his whole ministry was a power demonstration because he was at the center of the Great Controversy. ${ }^{69}$ When John the Baptist sent his disciples to inquire from Christ, "Are you the one who is to come, or should we expect someone else?" (Luke 5:20), Jesus did not answer them with rational arguments. He rather used a demonstration of God's power in healing the sick, casting out evil spirits, and giving sight to the blind (Luke $5: 21)$.

Spiritual warfare was a natural part of Christ's ministry. ${ }^{70}$ According to Luke, it was Jesus' usual practice to heal the sick and deliver people from demon possession soon after entering a new territory (Luke 4:33-35, 39; 5:13-15; 6:6-10, 18-19). Because people in his ministry context were very concerned about spiritual power, he approached them at the point of their concern. He even instructed his disciples to use the same method whenever he sent them to prepare the way for him (Luke 9:1-6; 10:19).

A number of accounts in Acts show that power demonstrations were also a natural part of the apostles' ministry. John Wimber and Kevin Springer assert that "when first-

\footnotetext{
${ }^{68}$ The discussion of the power dimension of discipleship is lengthy compared to that of the previous two because this is one of the most important issues in mission in animistic contexts in general and in the Lobi context in particular.

${ }^{69}$ Ellen G. White, The Desire of Ages (Mountain View, CA: Pacific Press, 1940), 257.

${ }^{70}$ Paul G. Hiebert, "The Flaw of the Excluded Middle," in Perspective on the World Christian Movement, 4th ed., ed. Ralph D. Winter and Steven C. Hawthorne (Pasadena, CA: Institute of International Studies, 2009), 407.
} 
century Christians came to a new town, signs and wonders followed." ${ }^{\text {,1 }}$ These power demonstrations either gave credibility to the content of their preaching or at least drew attention to their ministry. In Acts 3:1-9 Peter and John healed a lame beggar and vv. 1126 show how this event gave Peter an audience and how he capitalized on the opportunity to share Jesus Christ. Acts 5:12-16 records that one of the things that attracted people to the early church was the expressions of the power of God at work in the apostles' ministry. Acts 8:4-8 gives a vivid account of the result of power demonstrations in Philip's ministry in Samaria,

Those who had been scattered preached the word wherever they went. Philip went down to a city in Samaria and proclaimed the Messiah there. When the crowds heard Philip and saw the signs he performed, they all paid close attention to what he said. For with shrieks, impure spirits came out of many, and many who were paralyzed or lame were healed. So there was great joy in that city. (emphasis added)

Just like these biblical peoples, most of the peoples today also see the world as inhabited by evil spirits that cause trouble if they are not appropriately dealt with. ${ }^{72}$ As such, the use of power demonstrations in mission is still necessary for both initial conversion and discipleship. Power demonstrations are also a vital part of the building up of the church. ${ }^{73}$ Animism with its strong emphasis on spiritual power is becoming more and more attractive to adherents of the major world religions. Its influence is seen in other religious movements such as New Age, folk Islam, folk Hinduism, Buddhism, and even among many professed Christians. Animistic beliefs are structured around the

\footnotetext{
${ }^{71}$ Wimber and Springer, Power Evangelism, 186.

${ }^{72}$ Charles H. Kraft, "Spiritual Power: A Missiological Issue," in Appropriate Christianity, ed. Charles H. Kraft (Pasadena, CA: William Carey, 2005), 362.

${ }^{73}$ Rick Love, "Power Encounter Among Folk Muslims: An Essential Key of the Kingdom,” IJFM 13, no. 4 (October-December, 1996): 194.
} 
understanding that "the physical world is interpenetrated with spiritual forces both personal and impersonal to the extent that objects carry spiritual significance and events have spiritual causes." ${ }^{.74}$ People who come from these power-oriented religious contexts are occupied with spirit powers, charms, and amulets because they believe they are at the mercy of evil spirits, demons, the evil eye, curses, and other spiritual forces. They live in a constant state of fear of retaliation of the spirits, or the harm an enemy can place on them through some form of spiritual power. ${ }^{75}$ As such, they are more concerned about healing, deliverance, and protection than they are about truth. Therefore, "the Christ who is the remedy for their fears will often be more attractive than the Christ who saves them from their sins." ${ }^{.76}$

With the majority of the world, including most of the adherents of the major world religions, involved in animistic practices, ${ }^{77}$ it is crucial to give due consideration to the issue of redemptive power demonstrations in Christian witness. In many instances the success of Christian witness depends on it. ${ }^{78}$ On the one hand, when converts from an animistic background "find within Christianity little or none of the spiritual power they crave for the meeting of their needs for healing, blessing, guidance, even deliverance from demons, they continue their preChristian practice of going to shamans, priests,

\footnotetext{
${ }^{74}$ Dean C. Halverson, ed., The Compact Guide to World Religions (Minneapolis, MN: Bethany House, 1996), 37, 38.

${ }^{75}$ Halverson, The Compact Guide to World Religions, 50.

${ }^{76} \mathrm{Kraft}$, Worldview for Christian Witness, 488.

${ }^{77}$ Charles H. Kraft, "Appropriate Contextualization of Spiritual Power," in Appropriate Christianity, ed. Charles H. Kraft (Pasadena, CA: William Carey, 2005), 377.

${ }^{78}$ Rick Love, "Church Planting Among Folk Muslims," International Journal of Frontier Missions 11, no. 2 (April 1994): 88.
} 
diviners, temples, shrines, and the like for spiritual power." ${ }^{19}$ This compromises their loyalty to God and makes their Christianity syncretistic. On the other hand, some traditional societies such as the Lobi put a lot of pressure on their members irrespective of their religious beliefs to take part in some practices that contain unbiblical elements. John Mbiti points out how the African social structure places an emphasis on community centeredness instead of individualism:

To be human is to belong to the whole community, and to do so involves participating in the beliefs, ceremonies, rituals and festivals of the community. ... A person cannot detach himself from the religion of his group, for to do so is to be severed from his roots, his foundation, his context of security, his kinships and the entire group of those who make him aware of his own existence. To be without one of these corporate elements of life is to be out of the whole picture. ${ }^{80}$

What Mbiti expresses is very similar to the concept of 'lobiduur mentioned in chapter 2. Since full membership and fulfillment in such contexts come for individuals as they participate in family and community relationships (beliefs, ceremonies, rituals, and festivals), ${ }^{81}$ some converts to Christianity succumb to dual allegiance and syncretism as they continue to practice elements of their former religion. Because the social penalty for refusing to participate in some community rituals could be severe, many people, out of fear of the penalty prefer to follow the custom. ${ }^{82}$ This being the reality in which many sincere Christian converts find themselves, it is abnormal and even totally unacceptable that the power dimensions of biblical teaching continue to be ignored in Christian witness

\footnotetext{
${ }^{79}$ Kraft, "Spiritual Power,” 361.

${ }^{80}$ Mbiti, African Religions and Philosophy, 2.

${ }^{81}$ Partridge, Introduction to World Religions, 127.

${ }^{82} \mathrm{Kraft}$, Worldview for Christian Witness, 33.
} 
and discipleship. Spiritual warfare is a reality that Jesus did not ignore in his ministry. He did not see Satan and demonic forces as myths and superstition. He saw these forces as real enemies from which people needed to be set free. ${ }^{83}$

Things will be different for converts from an animistic background only when they experience the Christian God as a God of power able to control the enemy spirits and how they interfere in their lives. The worldview of animistic converts to Christianity does not get transformed just by hearing about God's power but by experiencing it personally, for it is "spiritual power to heal, bless and to overcome the power of demonic spirits that have held animists captive for generations, that really speaks to them." 84 According to Alan Tippett, in a power-oriented society, change of faith must be powerdemonstrated because many animists need a visible demonstration of the superior power of God to become Christians. ${ }^{85}$

Many converts from animism feel that some of their former practices, though clearly unbiblical, are still important in their struggle for human existence both spiritually and materially. ${ }^{86}$ As such, the church cannot afford to just condemn these practices as a denial of the Christian faith. With animism being a worldwide phenomenon, if the church sticks to the approach that emphasizes only the truth and allegiance dimensions in Christian witness, Christianity will be speaking to the majority of its converts in alien

${ }^{83}$ C. Peter Wagner, Spiritual Warfare Strategy: Confronting Spiritual Powers (Shippensburg, PA: Destiny Image Publishers, 1996), 119-136.

${ }^{84}$ Kraft, Worldview for Christian Witness, 483, 486.

${ }^{85}$ Alan Tippett, People Movements in Southern Polynesia: Studies in the Dynamics of Churchplanting and Growth in Tahiti, New Zealand, Tonga, and Samoa (Chicago, Moody Press, 1971), 81.

${ }^{86}$ Amanze, "Christianity and Ancestors Veneration in Botswana," 43. 
tones. While the Church is right in decrying the unbiblical beliefs and practices associated with dual allegiance and syncretism, it also needs to find effective and biblically appropriate ways to demonstrate that the God of the Bible is more powerful than other gods and spirits. In animistic contexts where spiritual power is a primary concern, redemptive power demonstrations are the clearest way to establish the superiority of God over their many spirits and gods. ${ }^{87}$

While firmly maintaining biblical integrity, the church in its mission must also be resourceful and flexible in adjusting its methods and procedures to the different contexts of the world in which it finds itself. The Church needs to realize and accept that "a Christianity that [merely] talks about and promises spiritual power but leaves out the experiencing in this area . . . leaves itself open to the problem of dual allegiance." 88 Unless converts from animistic backgrounds experience a powerful Christianity, many of them will "continue to seek out the old power sources to satisfy their fears and needs." 89

When it comes to dealing with spiritual powers, those involved in Christian witness need to understand that Satan cannot be fought with cognitive knowledge alone. Satanic powers cannot be effectively challenged only by biblical knowledge and truth. They must be opposed by the power of God. Christian witness is done only in part when it simply points out the errors of other religions and fails to deal with the spiritual powers

\footnotetext{
${ }^{87}$ Tippett, People Movements in Southern Polynesia, 81. See also Kraft, Anthropology for Christian Witness, 452.

${ }^{88}$ Charles H. Kraft and Marguerite G. Kraft, "Communicating and Ministering the Power of the Gospel Cross-Culturally: The Power of God for Christians Who Ride Two Horses," in The Kingdom and the Power, ed. Gary S. Greig and Kevin N. Springer (Ventura, CA: Regal Books, 1993), 350. 342

${ }^{89}$ Bruce L. Bauer, “A Response to Dual Allegiance,” Evangelical Missions Quarterly (July 2008):
} 
that drive these faiths. Satanic powers must be fought with the power of Christ for those under their influences to be converted and freed. The truth that sets free (John 8:32) is an experienced truth and not just an intellectual one. ${ }^{90}$

The Bible describes our world as including Satan and other demonic beings. Ellen White also asserts that no one "can doubt that satanic agencies are at work among men with increasing activity to distract and corrupt the mind, and defile and destroy the body." 91 She adds that, unfortunately,

while the world is filled with these evils, the gospel is too often presented in so indifferent a manner as to make but little impression upon the consciences or the lives of men. Everywhere there are hearts crying out for something which they have not. They long for a power that will give them mastery over sin, a power that will deliver them from the bondage of evil, a power that will give health and life and peace... . The world needs today what it needed nineteen hundred years ago-a revelation [of the power] of Christ. ${ }^{92}$ (emphasis added)

Toward a balanced approach. Christian discipleship can be likened to a threelegged stool. Just as a three-legged stool needs all three legs to stay balanced, Christian discipleship must solidly rest on all its dimensions - truth, allegiance, and power. Truth

\footnotetext{
${ }^{90}$ See C. Peter Wagner, "Missiology and Spiritual Power," in Paradigm Shifts in Christian Witness: Insights from Anthropology, Communication, and Spiritual Power, ed. Charles E. Van Engen, Darrell Whiteman, and J. Dudley Woodberry (Maryknoll, NY: Orbis Books, 2008), 91-97; J. Dudley Woodberry, "Power and Blessing: Keys to Relevance to a Religion as Lived," in Paradigm Shifts in Christian Witness: Insights from Anthropology, Communication, and Spiritual Power, ed. Charles E. Van Engen, Darrell Whiteman, and J. Dudley Woodberry (Maryknoll, NY: Orbis Books, 2008), 98-105; John Travis and Anna Travis, "Deep-Level Healing Prayer in Cross-Cultural Ministry: Models, Examples, and Lessons," in Paradigm Shifts in Christian Witness: Insights from Anthropology, Communication, and Spiritual Power, ed. Charles E. Van Engen, Darrell Whiteman, and J. Dudley Woodberry (Maryknoll, NY: Orbis Books, 2008), 106-115; Tormod Engelsviken, "Spiritual Conflict: A Challenge for the Church in the West with a View to the Future," in Paradigm Shifts in Christian Witness: Insights from Anthropology, Communication, and Spiritual Power, ed. Charles E. Van Engen, Darrell Whiteman, and J. Dudley Woodberry (Maryknoll, NY: Orbis Books, 2008), 116-125; and Kraft, Worldview for Christian Witness, 488, 489. See also Kraft, "Spiritual Power,” 363.

${ }^{91}$ Ellen G. White, Ministry of Healing (Mountain View, CA: Pacific Press, 1909), 143.

${ }^{92}$ Ibid.
} 
and allegiance dimensions of discipleship are not the only dimensions portrayed in

\section{Scripture.}

Jesus spent most of his time teaching truth. . . A As He taught, though, He constantly invited people into greater and greater allegiance to Him and His Father. In conjunction with the teaching of truth and the appeals for allegiance, He regularly freed people from the enemy's captivity through His use of God's power. ${ }^{93}$

Instead of the truth and power dimensions supporting the allegiance dimension as suggested by Kraft (figure 2), I submit that it is all three - truth, allegiance, and power dimensions - that are intended to support the believer's discipleship (figure 3).

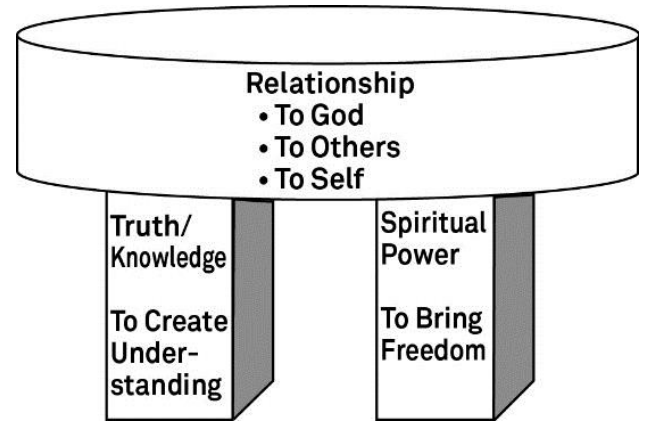

Figure 2. The relation between the three dimensions as proposed by Charles Kraft. From Charles H. Kraft, "Contextualization in Three Crucial Dimensions," in Appropriate Christianity, ed. Charles H. Kraft (Pasadena, CA: William Carey, 2005), 104.

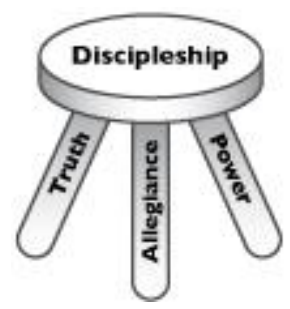

Figure 3. Discipleship supported by its truth, allegiance, and power dimensions.

\footnotetext{
${ }^{93} \mathrm{Kraft}$, Anthropology for Christian Witness, 452.
} 
The truth dimension (cognitive knowledge) is the appropriate antidote for ignorance and/or error. The allegiance dimension (commitment to Jesus Christ) is what is needed to replace any other previous commitment in a person's life and keep him/her from dual allegiance. Together, the truth and allegiance dimensions also help a person to relate better to others and to self. The power dimension (spiritual warfare) is the appropriate antidote for satanic captivity and harassment. Effective Christian witness is not a matter of either/or when it comes to appealing to these three dimensions because we can't fight a wrong primary allegiance with either knowledge or power. We can only fight one allegiance with another allegiance. Likewise, we cannot fight error or ignorance with either an allegiance or with power. These must be fought with knowledge and truth. So also with power. We cannot fight power with knowledge or truth, only with power. In other words, we fight allegiance with allegiance, truth with truth, and power with power. ${ }^{94}$

There is a need to use all three dimensions together, not separately in missionary witness. The need for the interconnectedness of the three dimensions of discipleship is well expressed as follows:

People need freedom from the enemy to (1) open their mind to receive and understand truth (2 Cor 4:4) and (2) to release their wills so they can commit themselves to God. However, they can't understand and apply Christian truth, nor can they exercise power, without a continuing commitment to God. Nor can they maintain the truth and their allegiance without freedom from the enemy won through continual power encounters. We constantly need each of the three dimensions in our lives. ${ }^{95}$

Biblical Christianity emphasizes truth, allegiance, and power. Western Christianity, which influences the rest of the Christian world, is very strong on the truth dimension, a little weak on the allegiance dimension, but very deficient in dealing with

\footnotetext{
${ }^{94}$ Kraft, "Contextualization in Three Crucial Dimensions," 100.

${ }^{95} \mathrm{Kraft}$, "Three Encounters in Christian Witness," 448.
} 
spiritual powers. ${ }^{96}$ For wholistic Christian witness, none of the three dimensions can be de-emphasized or neglected. Though prominent in Scripture, truth is never an end in and of itself. It is always balanced by concern for an intimate relationship with God and his power (Mark 10:17-27). The same is true when it comes to spiritual power; it is always balanced by a concern for a relationship with God and his truth (Luke 10:15-20). Any evangelistic strategy that promotes the power dimension without giving sufficient consideration to the truth and allegiance dimensions is not biblically balanced. Not everyone who saw or even experienced power events in Jesus's ministry turned to him in faith (Luke 17:11-19). Therefore, there must be balance and interdependence between the three dimensions.

Truth, allegiance, and power dimensions of discipleship appear both implicitly and explicitly throughout Jesus' ministry. In his ministry, power demonstrations were a means to an end, that is, discipleship, not ends in themselves. Through his teaching and power demonstrations, Jesus' aim was to lead people into a saving relationship with God.

\section{Theological and Missiological Perspectives on Culture}

\section{Working Definitions of Culture}

Scores of definitions of the term culture have been offered in the social sciences.

Two of the definitions that are the most relevant to my study are discussed below.

Paul Hiebert defines culture as "the more or less integrated system of ideas, feelings, and values and their associated patterns of behavior and products shared by a

\footnotetext{
${ }^{96}$ Wimber and Springer, Power Evangelism, 187.
} 
group of people who organize and regulate what they think, feel, and do."97 In other words, culture is a set of assumptions, beliefs, values, understandings, and meanings held in common by a society and used to guide their perceptions, judgments, and behaviors in their day-to-day life.

For Louis Luzbetak, culture is " a dynamic system of socially acquired and socially shared ideas according to which an interacting group of human beings is to adapt itself to its physical, social, and ideational environment"98 (emphasis in the original). Culture determines the rules according to which a person is to interact with others in a group. Three significant characteristics of culture in this definition are: (1) culture is dynamic, that is, culture constantly changes; (2) culture is socially acquired (learned) rather than biologically determined or race-restricted; and (3) culture is a system of strategies for coping with a group's environment.

\section{A Theological Perspective on Culture}

In his book Christ and Culture, Richard H. Niebuhr presents five paradigms as possible attitudes of Christians to culture: Christ against Culture, Christ of Culture, Christ above Culture, Christ and Culture in Paradox, and Christ the Transformer of Culture. These models portray culture in generalized terms as a monolith to which a Christian must take a single attitude. ${ }^{99}$

The "Christ against Culture" position perceives an opposition between Christ and

\footnotetext{
${ }^{97}$ Hiebert, Anthropological Insights for Missionaries, 30.

${ }^{98}$ Louis J. Luzbetak, The Church and Cultures: New Perspectives in Missiological Anthropology (Maryknoll, NY: Orbis Books, 1988), 74.

${ }^{99}$ Richard H. Niebuhr, Christ and Culture (New York: Harper \& Brothers, 1951).
} 
human culture. It stresses that "whatever may be the customs of the society in which the Christian lives, and whatever the human achievements it conserves, Christ is seen as opposed to them, so that he confronts men with the challenges of an 'either-or' decision." 100 In other words, true Christians must be very serious about holiness, which means withdrawing from the world into separate communities of believers. ${ }^{101}$ The majority of the early cross-cultural missionaries, including Adventists, viewed the religious piety of Africans as wholly erroneous and some even regarded it as their duty to wipe it out and replace it with a transformed character. ${ }^{102}$ This position should have led them to reject their own cultures also. The indiscriminate rejection of traditional customs was often rooted in the missionaries' ethnocentric tendency to associate the gospel with their own culture and, as a result, they judged all other cultural ways as bad. Although it is clear that Christ is against some elements of every culture, this paradigm's "call for separation tends to minimize the potential influence that Christianity may have for good upon society."103

The advocates of the "Christ of Culture position" perceive God's total approval of human cultures through the incarnation of Jesus whereby he entered the history and the

${ }^{100}$ Niebuhr, Christ and Culture, 140.

${ }^{101}$ Thomas K. Johnson cites the Old Order Amish made up of descendants of Swiss and Alsatian Anabaptists of the 16th century as a contemporary example of the advocates for the "Christ against Culture" paradigm. "Christ and Culture," Evangelical Review of Theology 35 (2011): 4-7.

${ }^{102}$ Stefan Höschele, Christian Remnant-African Folk Church: Seventh-day Adventism in Tanzania, 1903-1980 (Boston, MA: Brill, 2007), 262. See also Felix Chingota, "A Historical Account of the Attitude of Blantyre of the Church of Central Africa Presbyterian towards Initiation Rites," in Rites of Passage in Contemporary Africa: Interaction between Christian and African Traditional Religions, ed. James L. Cox (Cardiff, UK: Cardiff Academic Press, 1998), 147.

${ }^{103}$ Rick Allbee, "Christ Witnessing to Culture: Toward a New Paradigm between Christ and Culture," Stone-Campbell Journal 8 (Spring 2005): 18. 
particularities of the Jewish culture, learned to speak their language, ate the same food as his contemporaries, dressed the way they did, and attended their social events. For them, Jesus is "a great hero of human culture history; his life and teachings are regarded as the greatest human achievement; ... he confirms what is best in the past, and guides the process of civilization to its proper goal." 104 This position thus tends toward an uncritical accommodation of cultural values as it often feels no great tension between the church and the secular world. ${ }^{105}$ By making little distinction between Christ and culture, it also tends to drift towards humanism, animism, or whatever the prevailing view is in a given culture. ${ }^{106}$

The "Christ above Culture" paradigm seeks to stay away from both an uncritical accommodation to culture and a complete denial of the validity of culture in the process of gospel transmission. While it elevates and validates the positive dimensions of culture, it rejects the cultural values that are antagonistic to the gospel. ${ }^{107}$ Nevertheless, this paradigm hardly acknowledges that even though God exists outside of human culture, the Scriptures reveal that "he is willing to enter human culture and work through it in order to engage in meaningful communication with humans."108

The "Christ and Culture in Paradox" position is that of the dualists. By making a

${ }^{104}$ Niebuhr, Christ and Culture, 41.

${ }^{105}$ Tennent, Invitation to World Missions, 161. 1998): 319 .

${ }^{106}$ Paul G. Schrotenboer, "Christ and Culture," Evangelical Review of Theology 22 (October (2007): 35 .

${ }^{107}$ Paul Louis Metzger, "Christ, Culture, and the Sermon on the Mount Community," Ex Auditu 23

${ }^{108}$ Glenn Rogers, The Bible Culturally Speaking: The Role of Culture in the Production, Presentation and Interpretation of God's Word (Bedford, TX: Mission and Ministry Resources, 2004), 31. 
sharp distinction between the temporal and spiritual life, and between the reign of Christ and human culture, ${ }^{109}$ this paradigm is unable to reach a meaningful synthesis of Christians' attitude to culture. ${ }^{110}$ It struggles with the acknowledgment that although the world is in a fallen state, God still "uses human culture as a vehicle for interacting with humans." $" 111$

Niebuhr's last paradigm, "Christ the Transformer of Culture," "recognizes the corruption of culture but is optimistic and hopeful about the possibility of cultural renewal. Culture is perceived critically as perverted good, but not inherently evil. Conversion makes it possible for human beings and culture to move from selfcenteredness to Christ-centeredness."112

\section{A Missiological Perspective on Culture}

The "in the world" but "not of the world" concepts in John 17:14-18 constitute the basis of the recurrent problem involved in the discussion of Christians' attitude to culture. ${ }^{113}$ Because the followers of Christ are not of the world, many Christians have taken a negative attitude toward culture. But because believers are also reminded of the fact that they are in the world, some see the need for Christians to interact with their culture. There is thus an ongoing conflict among Christians on what their attitude should

${ }^{109}$ Niebuhr, Christ and Culture, 171.

${ }^{110}$ Allbee, "Christ Witnessing to Culture," 19.

${ }^{111}$ Rogers, The Bible Culturally Speaking, 27.

${ }^{112}$ Guenther, “The 'Enduring Problem' of Christ and Culture,” 217-218.

${ }^{113}$ Henry R. Van Til, The Calvinistic Concept of Culture (Grand Rapids, MI: Baker Academic, 2001), 15. 
be toward culture. In their struggle with the practical, everyday issues of life, Christians are confronted by the dilemma of how to be "in the world" but not "of the world."114 Therefore, an understanding of the role of culture and the Christian attitude toward it is of great importance both in determining what the Bible says and in communicating the Bible's message in meaningful terms that are understandable by people in various cultures. ${ }^{115}$ My proposed Christian perspective on culture builds on Charles H. Kraft, Timothy C. Tennent, Paul G. Hiebert, and Glenn Rogers's perspectives on the role of culture in the presentation of the gospel.

Charles Kraft argues that Jesus' incarnation into the cultural life of first-century Palestine to communicate with people is sufficient proof that "God takes culture seriously and ... is pleased to work through it to reach and interact with humans." ${ }^{116} \mathrm{Kraft}$ assumes that God created humanity with a culture-producing capacity and "views human culture [although tainted by sin] primarily as a vehicle to be used by him and his people for Christian purposes, rather than an enemy to be [always] combated or shunned."117 The "do not love the world or anything in the world" of 1 John 2:15-16 and "the whole world is under the control of the evil one" of 1 John 5:19 are not a call to reject culture but rather a call to refrain from participation with Satan in his use of one's culture. God's

\footnotetext{
${ }^{114}$ Craig A. Carter, Rethinking Christ and Culture: A Post-Christendom Perspective (Grand Rapids, MI: Brazos Press, 2006), 74.

${ }^{115}$ Eunice Okorocha, "Cultural Issues and the Biblical Message," in Africa Bible Commentary (Grand Rapids, MI: Zondervan, 2006), 1467.

${ }^{116} \mathrm{Kraft}$, Anthropology for Christian Witness, 33.

${ }^{117}$ Charles H. Kraft, Christianity in Culture: A Study in Biblical Theologizing in Cross-Cultural Perspective (Maryknoll, NY: Orbis books, 2005), 81.
} 
true attitude toward culture is that he "seeks to cooperate with human beings in the use of their culture for his glory. It is allegiance to the satanic use of that same culture that he stands against, not the culture itself" ${ }^{118}$ (emphasis in the original). Although God is above culture as it is warped by the pervasive influence of human sinfulness, nevertheless "culture [like individual temperaments] is not in and of itself either an enemy or a friend to God or humans. It is, rather, something that is there to be used by personal beings such as humans, God, and Satan."119

Timothy C. Tennent also argues that God acts in a redemptive way within human culture as its author and sustainer. He views the incarnation of Jesus as not only a revelation of God to humanity but "God the Father's validation of the sanctity of human culture... . The true union of God and man in one person is the ultimate rebuke against the secularization of culture"120 (emphasis in the original). He nevertheless warns against the uncritical divinization of culture. ${ }^{121}$

Hiebert also affirms that every culture has positive elements that can be used by Christians as well as aspects which express the demonic and dehumanizing forces of evil that must be challenged. ${ }^{122}$ Nevertheless he strongly maintains that

all authentic communication of the gospel in missions should be patterned on biblical communication and seek to make the Good News understandable to people within their own cultures. All cultures can adequately serve as vehicles for the communication of the gospel. If it were not so, people would have to change cultures

\footnotetext{
${ }^{118}$ Kraft, Christianity in Culture, 83.

${ }^{119}$ Ibid., 89.

${ }^{120}$ Tennent, Invitation to World Missions, 179, 181.

${ }^{121}$ Ibid., 181.

${ }^{122}$ Hiebert, Anthropological Insights for Missionaries, 56.
} 
to become Christians. This does not mean that the gospel is fully understood in any one culture, but that all people can learn enough to be saved and to grow in faith within the context of their own culture. ${ }^{123}$

The passages in 1 John 2:15-16 ("do not love the world or anything in the world") and 5:19 ("the whole world is under the control of the evil one") are not the only biblical references concerning the attitude of God or Christians toward "the world." The Greek word kosmos for "world" used in 1 John 2:15-16 and 5:19 is also the word employed in John 3:16 in reference to the world as the object of God's abundant love. Kosmos is also the word Jesus used in his intercessory prayer for his disciples in John 17:14-18:

I have given them Your word; and the world has hated them because they are not of the world, just as I am not of the world. I do not pray that You should take them out of the world, but that You should keep them from the evil one. They are not of the world, just as I am not of the world. Sanctify them by Your truth. Your word is truth. As You sent Me into the world, I also have sent them into the world.

In this prayer, Jesus does not ask the Father to take his disciples out of the world, but rather to protect them from the evil one as they remain in the world. Although Jesus also prays for his disciples' holiness ("Sanctify them by Your truth," v. 17) and calls us to holiness and warns us not to be conformed to this world, he nevertheless wants his followers to be in the world. "Probably Jesus recognized that the real problem with worldliness is not something 'out there in the world,' but rather something deep inside ourselves — our own unbelief, pride and ingratitude toward God. All this could easily come along with us, if we try to withdraw from the world into holy communities." 124

\footnotetext{
${ }^{123}$ Hiebert, Anthropological Insights for Missionaries, 55.

${ }^{124}$ Johnson, "Christ and Culture," 5.
} 
Therefore, 1 John 2:15-16 and 5:19 should not be interpreted as a call to reject culture. Read together with John 17:14-18, these texts are better understood as a call to live in real contact with culture without letting one's identity, thoughts, priorities, feelings, and values be controlled by it. God not only redeems people from the godlessness of their cultures $(1$ Pet 1:18, 19) when they accept Christ as their Savior, he also sends his people back into the same godless cultures as light bearers to work with him for the cultures' transformation. In other words, while we continue to be in contact with the culture, our identity, thoughts, priorities, feelings, and values should be continually sanctified by the truth - the living Word of God. And as such sanctified people, Jesus sends us into the world in a way that is similar to how the Father sent Jesus into the world. We can probably summarize the central thrust of this biblical text [John 17:14-18] by saying: Jesus wants us to be in the world but not of the world for a very specific purpose: He has sent us into the world as hearers and bearers of the Word. ${ }^{125}$ (emphasis in the original)

God is not bound by culture. In his interactions with human beings, he can choose to limit himself to the capacities of culture because of human finiteness or transcend cultural limitations. Because human beings are created in the image of God, their cultures can be seen as God's creative design; but because of the far-reaching effects of sin, all human cultures are sin-tainted. However, despite the effects of sin, God's revelation still occurs within the particularities of human culture. ${ }^{126}$ God's revelation of himself in the Old and New Testaments took place within the context of human cultures. Today as well, God's self-disclosure still encounters people within their specific cultural settings with the gospel sitting in judgment over all cultures and calling all of them to change. Glenn

\footnotetext{
${ }^{125}$ Johnson, "Christ and Culture," 6.

${ }^{126}$ Tennent, Invitation to World Missions, 172, 173.
} 
Rogers sums up this vital fact by pointing out that

God interacted with Abraham, Israel, and the Prophets, with Jesus, with the apostles, and with every one of us (including you and me) not in some otherworldly or heavenly context, but in the context of this material world, a world of human culture. ... God uses human culture as a vehicle for interaction and communication with humans because human culture is the only context in which humans can communicate. This is not because God is limited. It is because humans are limited. Human culture is the only frame of reference humans have. If God wants to communicate with humans it must be within the framework of human culture. ${ }^{127}$

A crucial point to take note of is that sin neither invalidates the Christians' cultural mandate nor excuses Christians from fulfilling their God-given mission of participating in the redemption of fallen humanity. The Christian expectation of future glory and complete redemption has implications for believers' attitude toward culture. The salt of the world metaphor (Matt 5:13) is an evangelistic call to intermingle with the world and transform it. As disciple-makers and ambassadors for Christ (Matt 28:18-20; 2 Cor 5:20) and salt and light of the world (Matt 5:13-16), it is not possible to visualize the Christian movement apart from human culture. ${ }^{128}$ "Just as Jesus incarnated himself into Jewish culture, so his religion is to be incarnated into every culture."129

\section{Creating Functional Substitutes for Lobi Funeral Rites}

Functional substitutes refer to the new Christian ritual forms and practices created at the end of the process of critical contextualization to replace the unbiblical elements associated with traditional practices. Without them, the mere rejection of old customs will

${ }^{127}$ Rogers, The Bible Culturally Speaking, 27, 28.

${ }^{128}$ Van Til, The Calvinistic Concept of Culture, 17, 57.

${ }^{129}$ Gorden R. Doss, "Shifting Worldviews in Encounter of African Traditional Religion and Christianity" (paper presented at the Fifth Annual Andrews University Seminary Scholarship Symposium, Berrien Springs, MI, February 2009), 1. 
create a cultural void leading to the rejection of the gospel as foreign, or the old practices will simply go underground. ${ }^{130}$ Biblically faithful and culturally relevant functional substitutes thus minimize the risk of syncretism as well as the cultural and social dislocation created by the rejection of the whole or parts of traditional rituals. ${ }^{131}$ Prescribing specific functional substitutes for the traditional Lobi funeral rites is against the philosophy of critical contextualization and beyond the scope of this dissertation. The creation of functional substitutes is the final step of the process of critical contextualization and must necessarily involve the Lobi believers as a hermeneutical community. However, my life experience and my research lead me to make some tentative suggestions.

My research shows that the following features of Lobi funeral rites are major issues: divination associated with finding the cause of death, throwing cowries at the feet of the deceased to fund their afterlife, carving an ancestral shrine at the end of the second funeral rite, shaving the heads of the deceased's close relatives, and whitewashing the orphans, widows, and the widower. Each of these elements of their funeral rites needs to be either discarded, modified, or reinterpreted. But before taking any action, a comprehensive Bible study on death as the foundation for biblical funeral services should be conducted with the Lobi believers.

What is a Lobi Adventist to do in the event of the death of a relative or during funeral rites? The following suggestions could be considered for each of these core

\footnotetext{
${ }^{130}$ Hiebert, Anthropological Insights for Missionaries, 187.

${ }^{131}$ Tissa Weerasingha, "Karma and Christ: Opening Our Eyes to the Buddhist World," International Journal of Frontier Missions 10, no. 3 (July 1993): 103.
} 
practices of the Lobi funeral rites:

1. Divination to find the cause of death. This practice needs to be completely discarded because the Bible clearly condemns any attempt to contact the dead (Lev 20:6, 27; Deut 18:10-13). Instead of using nonbiblical methods as a means to come to terms with the loss of a dear one, members should be encouraged to put their faith in God and the hope of the resurrection of the dead. It also should be emphasized that as the result of sin, death is inevitable in this life.

2. Throwing of cowries at the feet of the deceased. This practice assumes that people take on another form of existence after death and that the living relatives should ensure the deceased's journey to the land of the ancestors by giving them cowries to pay for whatever is needed during this journey to balbulah. The practice of throwing cowries could be modified as follows: At the end of the mourning period, a freewill offering could be collected and prayed over for the welfare of the widow/widower and orphans in place of providing cowries to the dead for their journey to balbulah. If the deceased could see what is being done, they would be very gratified to know that their family is being cared for.

3. Carving of an ancestral shrine. A Christian memorial service could be organized, after which a picture of the deceased could be framed and kept in a designated room of the family house to remind the living relatives to learn from the life experiences of their deceased loved one. If the deceased had made any special wishes for the welfare of their family, such as the need to live in unity, solidarity, and commitment to God, these wishes should also be framed and placed beside their picture.

4. Shaving the head of the deceased's relatives. This is another practice that 
needs to be discarded on the basis of Deut 14:1-2. Although shaving the hair is not completely forbidden by Scripture, as a holy people, the Israelites were not to cut their hair in connection with mourning rites for the dead. Any attempt to establish contact with the dead is deemed by God as defiling. ${ }^{132}$ Because many people shave their head as a sign of mourning to prevent any kind of retaliation from the deceased, a special time of prayer and dedication should be observed to ask God to protect the deceased's relatives against any form of attack.

5. The practice of whitewashing. This practice is done to protect the widow/widower and orphans against the attack of evil spirits. To meet this need of protection, the widow/widower and orphans could be dressed in white, symbolizing their protection by Christ's righteousness. A special prayer session also should be organized for them. During this special time of prayer, the pastor and church elders should lay their hands on the widow/widower and orphans, anoint them, and pray that the power of the Holy Spirit will surround and continually protect them. In addition, the widow/widower and orphans should be encouraged to make a spiritual recommitment to God.

\section{Conclusion}

No form of Christianity is immune to religious syncretism. The growing acceptance of religious pluralism, some mission approaches to other religions and cultures, and the inadequate discipling of new converts are some of the major contributing factors to religious syncretism. To safeguard the church against this problem, it is essential to always engage in mission with a well-defined biblical and

\footnotetext{
${ }^{132}$ Block, Deuteronomy, 344-345.
} 
cultural model of discipleship, a balanced Christian perspective on the role of culture in the presentation of the gospel, and an appropriate way of dealing with people involved in religious syncretism. Also, the church must always encourage growth toward maturity in the Christian life. In other words, the presentation of the gospel as the gift for personal salvation always must be done with the corresponding call to discipleship. ${ }^{133}$

The gospel is always received from within one's own cultural identity, ${ }^{134}$ making it very difficult to assimilate a new idea except in terms of other ideas and concepts one already has. ${ }^{135}$ As such, it is very difficult to be relevant in our Christian witness if we do not know and address the issues with which the people we are trying to reach are wrestling. I agree with Jonathan Campbell when he argues that "the Gospel is often held captive by cultural ideologies, traditions and structures. In order for the Gospel to spread across cultures, it must be set free from the control of any single culture."136 Just as David did not let the weight and encumbrance of Saul's armor hinder him as he approached Goliath, "we must continually identify and remove those factors that inhibit the Body of Christ from moving freely ... [and] guard against anything that might violate New Testament patterns of mission that lead to the movement of the gospel across cultures."137 Because truth, allegiance, and power dimensions are present in God's activities in

\footnotetext{
${ }^{133}$ Paul E. Pierson, The Dynamics of Christian Mission: History through a Missiological Perspective (Pasadena, CA: William Carey International University Press, 2009), 319.

${ }^{134}$ Tennent, Invitation to Word Missions, 186.

${ }^{135}$ Andrew F. Walls, The Cross-Cultural Process in Christian History (Maryknoll, NY: Orbis Books, 2002), 35.

${ }^{136}$ Jonathan Campbell, "Releasing the Gospel from Western Bondage," IJFM 16, no. 3 (Winter 1999/2000): 167.

${ }^{137}$ Ibid., 170.
} 
the human sphere, and because spiritual warfare is a lifelong battle in every person's life, ${ }^{138}$ it is vital that all three dimensions be taken into consideration together, not separately. It is also important for all of these dimensions to be contextualized, that is, they need to be appropriate to the socio-cultural setting in which Christian witness takes place.

Since the Bible teaches that demonic activities will increase in the last days (1 Tim 4:1; Rev 16:13-14), Christian witness and discipleship will not be fully "biblical or relevant to most of the peoples of the world without a solid approach to spiritual power." ${ }^{139}$ Because most of the peoples of the world are power oriented, it is essential that Christian witness also takes into account the spiritual power dimension in its presentation of the gospel. Jesus commands his disciples to make other disciples by teaching them to obey everything he commanded (Matt 28:19, 20). What he commanded includes both what he said and what he did; and "prominent among the numerous things that Jesus had explicitly commanded his disciples to do was to minister, hands-on, with spiritual powers." ${ }^{140}$ Nevertheless, the power dimension of the gospel must never be presented or used at the expense of a proper emphasis on the truth and allegiance dimensions. Nor should an emphasis on truth and allegiance dimensions be made while neglecting the spiritual power dimension.

There is no shortcut in wholistic Christian witness and discipleship. In order to be

\footnotetext{
${ }^{138}$ Ellen G. White, My Life Today (Hagerstown, MD: Review and Herald, 1980), 313.

${ }^{139}$ Kraft, “Spiritual Power," 362.

${ }^{140}$ Wagner, "Missiology and Spiritual Power," 93.
} 
effective, we cannot deviate from Jesus' ministry example, for it is "Christ's method alone [that] will give true success in reaching the people. The Saviour mingled with men as one who desired their good. He showed His sympathy for them, ministered to their needs [he did not discriminate the needs to minister to], and won their confidence. Then He bade them, 'Follow Me.'"141

Although every culture needs to be transformed by the Spirit and the Word of God, ${ }^{142}$ it is still essential that the communication of the gospel, in whatever setting, seeks to make the gospel concepts and ideas relevant to people within their own cultures. ${ }^{143}$ However, the need to be culturally appropriate always should be closely coupled with an in-depth analysis of the Scriptures. Because "people can only understand that which is part of their cultural frame of reference," 144 the presentation of the gospel must be both biblically sound and culturally relevant in order to be meaningful to the receiving peoples.

The next chapter will summarize the dissertation, draw conclusions, and make some recommendations for enhancing effectiveness in cross-cultural mission.

\footnotetext{
${ }^{141}$ White, The Ministry of Healing, 143.

${ }^{142}$ Pierson, The Dynamics of Christian Mission, 257.

${ }^{143}$ Hiebert, Anthropological Insights for Missionaries, 55.

${ }^{144}$ Rogers, The Bible Culturally Speaking, 65.
} 


\section{CHAPTER 6}

\section{SUMMARY, CONCLUSION, AND RECOMMENDATIONS}

\section{Introduction}

The focus of this dissertation has been on the study of the traditional Lobi funeral rites in Burkina Faso with the aim of proposing a biblical and missiological framework for responding to the challenges these rites pose to Christian mission in general and to SDA mission in particular. The development of this framework took into account three facts: (1) mission is primarily God's prerogative, (2) the Bible remains the foundational handbook to guide the church's involvement in mission, and (3) human culture continues to be the arena of mission.

Because God is the prime mover of mission, everything undertaken by the church in mission needs to be strongly grounded in the Word of God, by carefully examining and learning from the way God interacted with previous generations. Since human culture is the arena of mission and thus greatly impacts the receptiveness of new thought and behavior, the presentation of the gospel also must be culturally relevant. This helps minimize the rejection of the gospel as foreign. Biblical coherence and cultural relevance in mission enhance the nurture of new believers and thus significantly minimize the risk of religious syncretism and dual allegiance among church members.

\section{Summary}

The traditional Lobi are very religious. Religion is a central element of their life 
and informs every aspect of their social and cultural life. Among the Lobi, rites of passage are seen as very important moments in the social and religious life of the community. It is through participation in these rites that an individual achieves social status and leadership roles in the community. Rituals related to funeral ceremonies, in particular, are of utmost significance. Because of the general belief among the Lobi that the dead are not actually dead and therefore that there is life after death, funeral rites are elaborate ceremonial occasions because they are considered to be the indispensable means by which human beings pass from the land of the living to that of the ancestors (the living dead). ${ }^{1}$ It is thought that if at death an individual cannot be joined to their ancestors, their whole achievement in this life amounts to nothing because they will be forever separated from their people. As a result, each family and clan member must be involved in securing the future of the rest of the family and clan members; and this means appropriately contributing for their well-being both in this life and the hereafter. ${ }^{2}$

To the traditional Lobi mind-set, life is meaningless without participation in the rites of passage prescribed and overseen by the ancestors. This is so because it is participation in such rites that gives a Lobi the Lobi identity. ${ }^{3}$ The societal pressure that this puts on church members leads some to succumb to syncretism and dual allegiance in order to be fully accepted as members of their community. The full participation of some church members in the traditional funeral rites results in three things: It weakens the witness of the church in their community, it increases societal pressure on other members

\footnotetext{
${ }^{1}$ Alenuma, "The Dagaare-Speaking Communities of West Africa," 9.

${ }^{2}$ Bognolo, Lobi, 10.

${ }^{3}$ Ibid., 8; Ovesen, "Initiation: A Folk Model among the Lobi," 164.
} 
who refuse to participate, and it creates conflict between church members who choose to participate in funeral rites and those who choose not to.

A biblical and missiological framework for responding to traditional customs and practices is therefore needed to help the universal gospel become particularized in the Lobi setting without compromising its core principles. ${ }^{4}$ This concept is found in God's dealings with Israel in Old Testament times whereby in some cases he worked through the Ancient Near Eastern culture rather than above it, while in other cases he completely opposed some of their cultural practices. ${ }^{5}$ The incarnation of Christ in the cultural context of first-century Palestine is a witness to God's willingness to work with a human point of reference. In his ministry, Jesus also applied the same principles while addressing the good news of God's reign to the specific context of the Jewish culture, not as a mere abstract concept or only as an ambiguous future reality but as a present truth that could meet their deepest felt needs. ${ }^{6}$ Likewise, the early church understood that all gospel communication is a contextual event, and that as such, the unchanging truths of the gospel cannot be effectively "experienced, celebrated, or communicated without being culturally embodied."7 According to 1 Cor 9:19-23, without compromising the divine insistence upon repentance and faith, Paul's method of presenting the gospel varied depending on the people he was trying to reach. ${ }^{8}$

${ }^{4}$ Tennent, Invitation to World Missions, 334.

${ }^{5}$ Hill and Walton, A Survey of the Old Testament, 157, 159. For a full discussion, see chap. 3.

${ }^{6}$ Tennent, Invitation to World Missions, 334.

${ }^{7}$ Ibid., 338.

${ }^{8}$ David J. Hesselgrave, Planting Churches Cross-Culturally: North America and Beyond (Grand Rapids, MI: Baker Books, 2000), 150. 
The contextual approach to missions is therefore not about producing a domesticated version of the gospel or diluting the gospel to make it suitable for the people we seek to reach. It is about seeking appropriate means of critically adapting the never changing Word of God to the ever changing world in which the church ministers, in such a way that the gospel "speaks to the total context of the people to whom it is addressed." ${ }^{9}$ Today also, if the Church really wants to impact more than the surface level of people's lives, it has no choice but to balance biblical integrity with relevancy in the cultural context of the people it seeks to reach with the gospel.

\section{Conclusion}

Mission has generally been associated with the activity of the church. This misconception has often caused the Christian Church to see itself both as the initiator of and authority for mission. Jürgen Moltmann addresses this misunderstanding by pointing out that "it is not the church that has a mission of salvation to fulfill in the world; it is the mission of the Son and the Spirit through the Father that includes the church." ${ }^{10}$ In other words, the missionary movement of which the church is a part has its source in the Triune God. ${ }^{11}$ Rightly understood, therefore, mission is primarily God's prerogative. It is about God and his redemptive purposes and initiatives in the world, totally apart from any actions, tasks, strategies, and initiative undertaken by the Church. Hence, "mission is far

\footnotetext{
${ }^{9}$ Timothy George, Galatians, The New American Commentary (Nashville, TN: Broadman and Holman, 1994), 321.

${ }^{10}$ Jürgen Moltmann, The Church in the Power of the Spirit: A Contribution to Messianic Ecclesiology (London: SCM Press, 1977), 64.

${ }^{11}$ Georg F. Vicedom, The Mission of God: An Introduction to a Theology of Mission (St. Louis, MO: Concordia, 1965), 5.
} 
more about God and who He is than about us and what we do."12 The story of Jonah, the headstrong prophet, is another biblical example that highlights the fact that missio Dei "precludes any ethnocentrism or parochialism in the way the contemporary church carries out its missionary task." ${ }^{13}$ This story is also a constant reminder that the God of mission is neither limited to nor will at any time succumb to the reluctance of the church to change. When it comes to mission, God is too big to be confined to any denomination's quest for orthodoxy.

The twenty-first-century Christian Church needs a reconversion to God's concept of mission to humanity. This was both the experience of the Apostles and the key to the early church's success in mission. Acts 10 is a biblical example of a double conversion. Cornelius and his family were converted to faith in Jesus as the Messiah; Peter and subsequently the leaders of the early church (Acts 15) were reconverted in the sense that submitting to the Holy Spirit, they accepted that God is free to use any means he chooses to expand his kingdom. This helped widen their missionary focus.

Because the Church is only graciously invited to participate in God's redemptive action, it is not an exaggeration to say that the Church's primary purpose is not about expanding its realm through numerical growth or any other means, but to be an emissary of the kingdom of God. To achieve that, Scripture, missiology, and ecclesiology need to be placed in the right perspective. Without the Scripture, mission would not be only impossible but inconceivable. It is Scripture that assigns the responsibility to be involved

\footnotetext{
${ }^{12}$ Tennent, Invitation to World Missions, 55.

${ }^{13}$ Köstenberger, "The Challenge of a Systematized Biblical Theology of Mission,” 456.
} 
in mission, gives us the gospel to be proclaimed in mission, instructs us on how to proclaim it, and gives the assurance that the gospel is God's power for salvation to every believer. ${ }^{14}$ At the same time, missiology should shape our particular construction of ecclesiology for a specific culture and not the other way around..$^{15}$ Acts 10 and 15 are biblical examples of how the early church's involvement in mission helped shape their ecclesiology. Without the Apostle Paul's involvement in mission, there would be little of what we now call the New Testament.

God's missionary passion to save the world (John 3:16) calls into question all human prejudice and preconceived ideas about human cultures. As such, any endeavor made by the Church on behalf of God must be based on a sound biblical theology of mission. Also, for the reason that mission always takes place in a particular context, all genuine communication of the gospel in missions should seek to make the gospel concepts and ideas relevant to people within their own cultures. While firmly maintaining biblical integrity, the Church in its mission also must be resourceful and flexible in adjusting its methods and procedures to the changing situations of the world in which it finds itself.

Although mission and ministry in traditional contexts also must focus on the importance of giving allegiance to Jesus Christ and being grounded in biblical truth, the contents of mission and ministry need to be packaged in such a way that they speak to

\footnotetext{
${ }^{14}$ John R. W. Stott, "The Living God Is a Missionary God," in Perspectives on the World Christian Movement, 4th ed., ed. Ralph D. Winter and Steven C. Hawthorne (Pasadena, CA: Institute of International Studies, 2009), 21.

${ }^{15}$ Eugene Bunkowske, "How Does God Build His Kingdom? A Case Study Approach," Missio Apostolica 20, no. 1 (May 2012): 30.
} 
people's existential needs of healing, protection from curses and evil spiritual powers, and people's yearning for blessings in every aspect of life. The Church needs to realize and accept that "a Christianity that [merely] talks about and promises spiritual power but leaves out the experiencing in this area... leaves itself open to the problem of dual allegiance." ${ }^{" 16}$ Unless the Church presents a powerful Christianity, many of its members will "continue to seek out the old power sources to satisfy their fears and needs." 17

\section{Recommendations}

The following seven recommendations are made in connection with several challenges brought to light in the process of writing this dissertation:

1. Emphasize a discipleship model of mission. Jesus' last command to his disciples was "Go therefore and make disciples of all the nations, baptizing them in the name of the Father and of the Son and of the Holy Spirit, teaching them to observe all things that I have commanded you; and lo, I am with you always, even to the end of the age" (Matt 28:19-20). The goal of the Great Commission is clearly to make disciples. Teaching and baptizing those who believe are the means of achieving this goal.

Unfortunately, the baptism of new converts is generally perceived as the goal and the measure of success in many missionary engagements. Apart from the focus on the fundamental beliefs of the church, little teaching is done after baptism to steadily nurture new converts. The assumed typical method of discipleship in this model of mission is 350.

\footnotetext{
${ }^{16} \mathrm{Kraft}$ and Kraft, "Communicating and Ministering the Power of the Gospel Cross-Culturally,
}

${ }^{17}$ Bauer, “A Response to Dual Allegiance," 342. 
theoretical and strongly leans towards passively listening to sermons with very little intentional and practical hands-on instruction of converts. Emmanuel Egbunu rightly remarks that "the neglect of thorough follow-up to conserve the fruits of evangelism has been the major factor for the prevalence of untaught Christians whose ideas of Christianity are a travesty of biblical discipleship." 18

Unless disciples are made, that is, converts are taught and see the need of obeying all the things Christ has commanded, there always will be syncretism and dual allegiance in the Church. An antidote may be in a shift from baptism as the measure of success in mission and ministry to an emphasis on long-term teaching and mentoring (beside weekly sermons) for discipleship. For example, there can be a two year formal discipleship plan for new converts. This should be a comprehensive discipleship curriculum. Beside a doctrinal instruction, new converts need to also be taught about personal spiritual life development, family life, and how to deal with particular cultural issues they are confronted with, etc.

2. Develop a biblical theology of conversion. There is more to conversion than a simple intellectual ascent to a body of doctrines. Conversion is also not about skillfully manipulating people's emotions so as to gain a certain kind of commitment to the church. Because conversion is generally perceived as an event in time, "the significance of process and development in Christian conversion is often neglected." ${ }^{19}$ If conversion was

\footnotetext{
${ }^{18}$ Emmanuel Egbunu, "To Teach, Baptize, and Nurture New Believers," in Mission in the $21^{\text {st }}$ Century: Exploring the Five Marks of Global Mission, ed. Andrew Walls and Cathy Ross (Maryknoll, NY: Orbis Books, 2008), 25.

${ }^{19}$ Frank D. Macchia, “Towards Individual and Communal Renewal: Reflections on Luke’s Theology of Conversion," Ex Auditu 25 (2009): 93.
} 
mainly a single event, it would seem strange for Christ to turn to Peter after the final supper and tell him, "Simon, Simon, Satan has asked to sift all of you as wheat. But I have prayed for you, Simon, that your faith may not fail. And when you have turned back [converted], strengthen your brothers" (Luke 22:31-32). According to Markus Bockmuehl, conversion here denotes "a moral and spiritual re-orientation." ${ }^{20}$ Because Peter was already a disciple, Bockmuehl further adds that "one surprising implication of Luke 22:31-32 is that even on the last night of Jesus' ministry the evangelist evidently regards Peter's "conversion" still to be in the future rather than the past."21 Therefore, rather than being a static category, Christian conversion should be understood as a dynamic one. ${ }^{22}$ As such, a well-defined biblical theology of conversion is needed for a balance between a believer's response to God and the activity of God in the life of that believer.

\section{Make use of a balanced approach to mission that includes power encounter.}

Mission is more than just preaching a set of correct doctrines no matter their importance. A mere intellectual assent to a body of correct doctrines is not enough to make a convert a disciple of Christ. A balanced discipleship includes both correct doctrinal knowledge and character development. In some instances, character development cannot happen unless people are first set free from the power of Satan. ${ }^{23}$ For this reason, ministry and

\footnotetext{
${ }^{20}$ Markus Bockmuehl, “The Conversion of Simon Peter,” Ex Auditu 25 (2009): 46.

${ }^{21}$ Ibid., 47.

${ }^{22}$ Stephen J. Chester, "Romans 7 and Conversion in the Protestant Tradition," Ex Auditu 25
} (2009): 135 .

${ }^{23}$ Wimber and Springer, Power Evangelism, 448. 
mission must necessarily combine the truth, allegiance, and power dimensions of the gospel. This pattern in Jesus' ministry is shown in Matt 4:23-25:

Jesus went throughout Galilee, teaching in their synagogues, proclaiming the good news of the kingdom, and healing every disease and sickness among the people. News about him spread all over Syria, and people brought to him all who were ill with various diseases, those suffering severe pain, the demon-possessed, those having seizures, and the paralyzed; and he healed them. Large crowds from Galilee, the Decapolis, Jerusalem, Judea and the region across the Jordan followed him.

Jesus skillfully combined the proclamation of the gospel with the demonstration of the power of God to set people free from the power of Satan. It is important to note that before Jesus stated the Great Commission, he assured his disciples that "all authority (exousia) in heaven and on earth" had been given to him and was available to them as they went and made disciples: "I am with you always" (Matt 28:18, 20). The disciples likely understood that their ministry was to be patterned after that of Christ. It is no wonder that "the book of Acts reveals that the disciples went out and spread the good news in the same fashion as Christ: by combining proclamation and demonstration of the kingdom of God. The apostles not only taught what they heard but also did what Jesus did."24

Although power demonstrations are not an end in themselves, through them people experience the power of God as greater than that of evil spirits and local divinities. They help confirm the claims of the Bible as the Word of the only true God and thus strengthen the converts' allegiance to Christ. ${ }^{25}$ Wimber and Springer capture the

\footnotetext{
${ }^{24}$ Wimber and Springer, Power Evangelism, 87.

${ }^{25}$ Tormod Engelsviken, "Spiritual Conflict: A Challenge for the Church in the West with a View to the Future," in Paradigm Shifts in Christian Witness: Insights from Anthropology, Communication, and Spiritual Power, ed. Charles E. Van Engen, Darrell Whiteman, and J. Dudley Woodberry (Maryknoll, NY: Orbis Books, 2008), 125.
} 
importance of signs and wonders in mission and ministry this way: "In power evangelism, resistance to the Gospel is overcome by the demonstration of God's power, and receptivity to Christ's claims is usually very high." 26

With the warning that demonic activities will increase in the last days (1 Tim 4:1; Rev 16:13-14), in order for Christian witness and discipleship to be relevant to most of the peoples of the world, witness and discipleship must necessarily reflect a solid approach to spiritual power. ${ }^{27}$ To be relevant in many contexts in general and in the Lobi context in particular, the Church needs an objective answer to the following question: If power demonstrations were an essential part of both Christ's and the early church's ministry, why are they absent from ours today?

\section{Facilitate open discussions in local churches on the impact of syncretism and} dual allegiance on the witness of the Church. Church members in the Lobi context are divided on the question of whether or not to participate in traditional funeral rites. While some members fully participate in them, others categorically refrain from participation because of the non-biblical elements they contain. This lack of unity among members, due to the practice of syncretism and dual allegiance by some members, affects the witness of the church. The witnessing done by members who stand firm for their faith is weakened or overshadowed by the behavior of other members who see no problem in participating in cultural practices that go against biblical principles. It is therefore important that open discussions on the impact of dual allegiance and syncretism on Christian witness be facilitated in local churches. This has the potential of being "a truth

\footnotetext{
${ }^{26}$ Wimber and Springer, Power Evangelism, 77.

${ }^{27}$ Kraft, "Spiritual Power,” 362.
} 
and reconciliation" forum as well as a discipleship program that also will help address other issues related to funeral rites of passages such as the need to develop functional substitutes.

5. Develop functional substitutes for non-biblical cultural practices. The mere rejection of traditional practices often creates a cultural void that can either lead to the rejection of the gospel as foreign, or that can cause the practices to simply go underground. ${ }^{28}$ Functional substitutes, new Christian ritual forms and practices, need to be created to replace the non-biblical elements associated with traditional practices. Biblically faithful and culturally relevant functional substitutes will minimize the risk of syncretism as well as the cultural and social dislocation created by the rejection of the whole or parts of traditional rituals..$^{29}$ New symbols and rituals need to be developed to communicate biblical principles in forms understandable to the Lobi context. The process of developing functional substitutes for the traditional Lobi funeral rites needs to be facilitated by the Burkina Faso SDA Mission and must actively involve the members of various local Lobi congregations because of their knowledge of the deeper and hidden meanings associated with their cultural practices. Involving the members directly affected by this change helps to ensure that the new Christian symbols and rituals survive over time.

6. Help church members attain economic independence. The societal pressure to conform to all aspects of a group's cultural practices is unbearable especially for church

\footnotetext{
${ }^{28}$ Hiebert, Anthropological Insights for Missionaries, 187.

${ }^{29}$ Tissa Weerasingha, "Karma and Christ: Opening Our Eyes to the Buddhist World," International Journal of Frontier Missions 10, no. 3 (July 1993): 103.
} 
members who are financially or materially dependent on non-Christian members of their families or community. In some cases the help these members receive from others is withdrawn once they decide to turn their backs on traditional practices that contradict their Christian faith. The fear of being abandoned by their families coupled with the local church's inability to meet their basic needs leads some converts into syncretism and dual allegiance.

In addition to spiritual empowerment, if members are also economically empowered, they would have a greater chance to withstand societal pressure to conform to non-biblical elements associated with some cultural practices. In this case, mission and sustainable economic development need to go hand in hand. The Burkina Mission, the Adventist Development and Relief Agency, ${ }^{30}$ and the local Dorcas Society ${ }^{31}$ can partner and provide church members with both entrepreneurial skills and means to run sustainable income-generating activities.

\section{Introduce a course on cultural anthropology in our theological institutions.}

Effective pastoral ministry is not built only around the ability to do good biblical exegesis. If theology is really "centered in the process of reflecting on and applying biblical truth to a particular situation,"32 the exegesis of the context in which the biblical text is to be applied cannot be ignored as separated from the process of doing theology. It is only by associating the exegesis of culture to the exegesis of biblical texts that our

\footnotetext{
${ }^{30}$ The official development and relief agency of the worldwide Seventh-day Adventist Church.

${ }^{31} \mathrm{~A}$ local church organization with a mission to help the less fortunate members.

${ }^{32}$ Jon Dybdahl, "Doing Theology in the Doctor of Ministry Program," https://www.andrews.edu/ $\mathrm{sem} / \mathrm{dmin} /$ about/theological-reflection/ (accessed January 12, 2015).
} 
theology will be both equipped to answer questions that our parishioners are asking and to confront different cultures with God's revelation in a way they can respond to and make intelligent decisions in favor of that revelation. It is not out of context to say that a useful theologian is one whose theology is relevant to their context. All gospel workers therefore must be equipped with tools to exegete their ministry context with the same rigor they apply to exegesis of biblical texts. This double exegesis will help them successfully address the cognitive, affective, and evaluative dimensions of people's lives. 


\section{BIBLIOGRAPHY}

Abasi, Augustine Kututera. "Lua-Lia, The 'Fresh Funeral': Founding a House for the Deceased Among the Kasena of North-East Ghana." Africa 65, no. 3 (1995): 448475.

Alenuma, Sidonia. “The Dagaare-Speaking Communities of West Africa.” Journal of Dagaare Studies 2 (2002): 10-16.

Allbee, Rick. "Christ Witnessing to Culture: Toward a New Paradigm between Christ and Culture.” Stone-Campbell Journal 8 (Spring 2005): 17-33.

Amanze, James N. "Christianity and Ancestors Veneration in Botswana." Studies in World Christianity 9, no. 1 (2003): 43-59.

Ball, Bryan W. "The Immortality of the Soul: Could Christianity Survive without It?" Ministry Magazine 83, no. 5 (May 2011): 14-17.

Bankole, Katherine Olukemi. "Birth." Encyclopedia of African Religion. Edited by Molefi Kete Asante and Ama Mazama. Los Angeles, CA: SAGE, 2009. 124-125.

Banks, Robert. Paul's Idea of Community. Exeter, UK: The Paternoster Press, 1980.

"Baptized for the Dead" [1 Cor 15:29]. Seventh-day Adventist Bible Commentary. Rev. ed. Edited by Francis D. Nichol. Washington, DC: Review \& Herald, 1976-1980. 6:807.

Bauer, Bruce L. "Avoiding Comfortable Syncretism by Doing Critical Contextualization." In Adventist Responses to Cross-Cultural Mission: Global Mission Issues Committee Papers, edited by Bruce L. Bauer, 2:245-262. Berrien Springs, MI: Department of World Mission, 2007.

. “A Response to Dual Allegiance.” Evangelical Missions Quarterly (July 2008): 340-347.

Bell, Catherine. Ritual: Perspectives and Dimensions. New York: Oxford University Press, 1997.

Bevans, Stephen B. Models of Contextual Theology. Maryknoll, NY: Orbis Books, 2002. 
Bloch-Smith, E. "From Womb to Tomb: The Israelite Family in Death as in Life." In The Family in Life and in Death: The Family in Ancient Israel, edited by Patricia Dutcher-Walls, 122-131. New York: T \& T Clark, 2009.

Block, Daniel I. The NIV Application Commentary: Deuteronomy. Grand Rapids, MI: Zondervan, 2012.

Boadt, Lawrence. Reading the Old Testament: An Introduction. Mahwah, NJ: Paulist Press, 1984.

Bockmuehl, Markus. "The Conversion of Simon Peter.” Ex Auditu 25 (2009): 42-60.

Bognolo, Daniela. Lobi. Milan, Italy: 5 Continents Press, 2007.

Bright, John. A History of Israel. London, UK: Westminster, 1981.

Brown, Rick. "Contextualization without Syncretism." International Journal of Frontier Mission 23, no. 3 (Fall 2006): 127-133.

Bruce, Gary M., Lynn H. Cohick, and Gene L. Green. The New Testament in Antiquity: A Survey of the New Testament within Its Cultural Contexts. Grand Rapids, MI: Zondervan, 2009.

Bunkowske, Eugene. "How Does God Build His Kingdom? A Case Study Approach." Missio Apostolica 20, no. 1 (May 2012): 30-50.

Burge, Gary M. The NIV Application Commentary: John. Grand Rapids, MI: Zondervan, 2000.

Cairus, Aecio E. "The Doctrine of Man.” In Handbook of Seventh-day Adventist Theology, edited by Raoul Dederen, 205-232. Hagerstown, MD: Review and Herald, 2000.

Campbell, Charles L. “John 1:1-14.” Interpretation 49, no. 4 (October 1995): 394-398.

Campbell, Jonathan. "Releasing the Gospel from Western Bondage." International Journal of Frontier Missions 16, no. 3 (Winter 1999/2000): 167-171.

Carlson, Richard P. "The Role of Baptism in Paul's Thought." Interpretation 47 (July 1, 1993): 255-266.

Carpenter, Mary Yeo. "Familism and Ancestor Veneration: A Look at Chinese Funeral Rites." Missiology: An International Review 24, no. 4 (October 1996): 503-517.

Carter, Craig A. Rethinking Christ and Culture: A Post-Christendom Perspective. Grand Rapids, MI: Brazos Press, 2006. 
Chester, Stephen J. "Romans 7 and Conversion in the Protestant Tradition." Ex Auditu 25 (2009): 135-171.

Chingota, Felix. "A Historical Account of the Attitude of Blantyre of the Church of Central Africa Presbyterian towards Initiation Rites." In Rites of Passage in Contemporary Africa: Interaction between Christian and African Traditional Religions, edited by James L. Cox, 146-156. Cardiff, UK: Cardiff Academic Press, 1998.

Clark, Robert E. "Baptism for the Dead and the Problematic of Pluralism: A Theological Reconfiguration." Dialogue: A Journal of Mormon Thought 30, no. 1 (Spring 1997): 105-116.

Cook, Stephen L. "Death, Kinship, and Community: Afterlife and the $70 \pi$ Ideal in Israel." In The Family in Life and in Death: The Family in Ancient Israel, edited by Patricia Dutcher-Walls, 106-121. New York: T \& T Clark, 2009.

Cox, James L. "Ritual, Rites of Passage and the Interaction between Christian and Traditional Religions." In Rites of Passage in Contemporary Africa: Interaction between Christian and African Traditional Religions, edited by James L. Cox, viii-xvi. Cardiff, UK: Cardiff Academic Press, 1998.

Cruz e Silva, Teresa, and Ana Laforte. "Christianity, African Traditional Religions and Cultural Identity in Southern Mozambique." In Rites of Passage in Contemporary Africa: Interaction between Christian and African Traditional Religions, edited by James L. Cox, 34-45. Cardiff, UK: Cardiff Academic Press, 1998.

de Rouville, Cécile. Organisation Sociale des Lobi: Une société Bilinéaire du Burkina Faso et de la Côte d'Ivoire. Paris, France: L'Harmattan, 1987.

DeMaris, Richard E. "Corinthian Religion and Baptism for the Dead (1 Corinthians 15:29): Insights from Archaeology and Anthropology." Journal of Biblical Literature 114, no. 4 (Winter 1995): 661-682.

. The New Testament in Its Ritual World. New York: Routledge, 2008.

DeSilva, David A. Honor, Patronage, Kinship \& Purity: Unlocking New Testament Culture. Downers Grove, IL: InterVarsity Press, 2000.

Dickson, Kwesi A. Theology in Africa. Maryknoll, NY: Orbis Books, 1984.

Doss, Gorden R. "The Jerusalem Council." In Adventist Responses to Cross-Cultural Mission: Global Mission Issues Committee Papers, edited by Bruce Bauer, 2:191-197. Berrien Springs, MI: Department of World Mission, 2007. 
Doss, Gorden R. "Shifting Worldviews in Encounter of African Traditional Religion and Christianity." Paper presented at the Fifth Annual Andrews University Seminary Scholarship Symposium, Berrien Springs, MI, February 2009.

Driver, John. Images of the Church in Mission. Scottsdale, PA: Herald Press, 1997.

Droogers, André, and Sidney M. Greenfield. "Recovering and Reconstructing Syncretism." In Reinventing Religions: Syncretism and Transformation in Africa and the Americas, 21-42. New York: Rowman and Littlefield, 2001.

Dybdahl, Jon. "Doing Theology in the Doctor of Ministry Program." https://www .andrews.edu/ sem/dmin/about/theological-reflection/ (accessed January 12, 2015).

Egbunu, Emmanuel. “To Teach, Baptize, and Nurture New Believers.” In Mission in the 21st Century: Exploring the Five Marks of Global Mission, edited by Andrew Walls and Cathy Ross, 25-36. Maryknoll, NY: Orbis Books, 2008.

Engelsviken, Tormod. "Spiritual Conflict: A Challenge for the Church in the West with a View to the Future." In Paradigm Shifts in Christian Witness: Insights from Anthropology, Communication, and Spiritual Power, edited by Charles E. Van Engen, Darrell Whiteman, and J. Dudley Woodberry, 116-125. Maryknoll, NY: Orbis Books, 2008.

Engle, Richard W. "Contextualization in Missions: A Biblical and Theological Appraisal." Grace Theological Journal 4, no. 1 (1983): 85-107.

Flanders, Henry Jackson, Robert Wilson Crapps, and David Anthony Smith. People of the Covenant: An Introduction to the Hebrew Bible. New York: Oxford University Press, 1996.

Flemming, Dean. Contextualization in the New Testament: Patterns for Theology and Mission. Downers Grove, IL: InterVarsity, 2005.

Foschini, Bernard. "Those Who Are Baptized for the Dead" 1 Cor. 15:29: An Exegetical Historical Dissertation. Worcester, MA: Heffernan Press, 1951.

Freeman, James M. The New Manners and Customs of the Bible. Gainesville, FL: Bridge-Logos, 1998.

Frykholm, Amy. "One Person, Two Faiths: Double Belonging." Christian Century, January 25, 2011, 20-23.

Fudge, Edward William. The Fire That Consumes: A Biblical and Historical Study of the Doctrine of Final Punishment. 3rd ed. Eugene, OR: Cascade Books, 2011. 
Galpaz-Feller, Pnina. “"And the Physicians Embalmed Him'(Gen 50.2).” Zeitschrift für die alttestamentliche Wissenschaft 118, no. 2 (2006): 209-217.

. The Exodus from Egypt: Reality or Illusion (Exodus 1-15). Tel Aviv, Israel: Schocken, 2002.

Gane, Roy. The NIV Application Commentary: Leviticus, Numbers. Grand Rapids, MI: Zondervan, 2004.

Geffré, Claude. "Double Belonging and the Originality of Christianity as a Religion." In Many Mansions? Multiple Religious Belonging and Christian Identity, edited by Catherine Cornille, 93-105. Maryknoll, NY: Orbis Books, 2002.

General Conference of Seventh-day Adventists. Seventh-day Adventists Believe: A Biblical Exposition of 27 Fundamental Doctrines. Washington, DC: Ministerial Association, 1998.

George, Timothy. The New American Commentary: Galatians. Nashville, TN: Broadman and Holman, 1994.

"Go to Thy Fathers" [Gen 15:15]. Seventh-day Adventist Bible Commentary. Rev. ed. Edited by Francis D. Nichol. Washington, DC: Review \& Herald, 1976-1980. 1:314315.

Goldingay, John. Old Testament Theology: Israel's Faith. Downers Grove, IL: InterVarsity Press, 2006.

Goody, Jack. Death, Property and the Ancestors: A Study of the Mortuary Customs of the Lodagaa of West Africa. Stanford, CA: Stanford University Press, 1962.

Gower, Ralph. The New Manners and Customs of Bible Times. Chicago, IL: Moody, 2005.

Green, Joel B. Body, Soul, and Human Life: The Nature of Humanity in the Bible. Grand Rapids, MI: Baker Academic, 2008.

Grimes, Ronald L. Beginnings in Ritual Studies. 3rd ed. Waterloo, Canada: Ritual Studies International, 2010.

Grudem, Wayne. Systematic Theology: An Introduction to Biblical Doctrine. Grand Rapids, MI: Zondervan, 1994.

Habermas, Gary R., and James P. Moreland. Beyond Death: Exploring the Evidence for Immortality. Wheaton, IL: Good News Publishers, 1998. 
Halevi, Yossi K. At the Entrance to the Garden of Eden: A Jew's Search for Hope with Christians and Muslims in the Holy Land. New York: Harper Perennial, 2002.

Hallote, Rachel S. Death, Burial, and Afterlife in the Biblical World: How the Israelites and Their Neighbors Treated Their Dead. Chicago, IL: Ivan R. Dee, 2001.

Halverson, Dean C. The Compact Guide to World Religions. Minneapolis, MN: Bethany House, 1996.

Hedlund, Roger E. "Religious Pluralism: Fact and Issue." In Many Other Ways? Questions of Religious Pluralism, edited by M. Bage, R. Hedlund, P. B. Thomas, Martin Alphonse, and George David, 13-27. New Delhi, India: Printsman, 1992.

Hesselgrave, David J. Planting Churches Cross-Culturally: North America and Beyond. Grand Rapids, MI: Baker Books, 2000.

Hesselgrave, David J., and Edward Rommen. Contextualization: Meanings, Methods, and Models. Grand Rapids, MI: Baker Books, 1989.

Hiebert, Paul G. Anthropological Insights for Missionaries. Grand Rapids, MI: Baker Academic, 1985.

. "The Flaw of the Excluded Middle." In Perspective on the World Christian Movement, edited by Ralph D. Winter and Steven C. Hawthorne, 407-414. Pasadena, CA: Institute of International Studies, 2009.

. Transforming Worldviews: An Anthropological Understanding of How People Change. Grand Rapids, MI: Baker Academic, 2009.

Hiebert, Paul G., R. Daniel Shaw, and Tite Tiénou. "Responding to Split-Level Christianity and Folk Religion." International Journal of Frontier Missions 16, no. 4 (Winter 1999/2000): 173-182.

. Understanding Folk Religion: A Christian Response to Popular Beliefs and Practices. Grand Rapids, MI: Baker Books, 1999.

Hill, Andrew E., and John H. Walton. A Survey of the Old Testament. Grand Rapids, MI: Zondervan, 2009.

Hillman, Eugene. Polygamy Reconsidered: African Plural Marriage and the Christian Churches. New York: Orbis Books, 1975. 
Höschele, Stefan. Christian Remnant-African Folk Church: Seventh-day Adventism in Tanzania, 1903-1980. Boston, MA: Brill, 2007.

Idowu, Bolaji. African Traditional Religion: A Definition. London, UK: SCM Press, 1973.

Imasogie, Osadolor. "The Nature of Rites of Passage in African Traditional Religion." Ogbomoso Journal of Theology 7 (December 1992): 13-17.

"In Our Image" [Gen 1:26]. Seventh-day Adventist Bible Commentary. Rev. ed. Edited by Francis D. Nichol. Washington, DC: Review \& Herald, 1976-1980. 1:216.

Ishola, Ademola S. "The Sociological Significance of the Traditional African Concept of Rites of Passage." Ogbomoso Journal of Theology 7 (December 1992): 26-32.

Jebadu, Alexander. "Ancestral Veneration and the Possibility of Its Incorporation into the Church." Exchange 36, no. 3 (2007): 246-2280.

Johnson, Luke Timothy. The Writings of the New Testament: An Interpretation. Minneapolis, MN: Fortress Press, 1999.

Johnson, Thomas K. "Christ and Culture." Evangelical Review of Theology 35 (2011): 4-16.

Johnston, Philip S. Shades of Sheol: Death and Afterlife in the Old Testament. Downers Grove, IL: InterVarsity Press, 2002.

The Joshua Project. www.joshuaproject.net/countries.php?rog3=UV (accessed December 7, 2014).

Joyce, James Daniel. "Baptism on Behalf of the Dead: An Interpretation of 1 Corinthians 15:29-34." Encounter 26, no. 2 (Spring 1965): 269-277.

Keathley, Hampton IV. "Discipleship Overview." Bible.org. www.http://bible.org/ article/discipleship-overview (accessed November 22, 2014).

Kaiser, Walter C. "The Book of Leviticus." The New Interpreter's Bible. Nashville, TN: Abingdon, 1994. 1:983-1191.

King, Philip J., and Lawrence E. Stager. Life in Biblical Israel. Louisville, KY: Westminster John Knox Press, 2001.

Köstenberger, Andreas J. "The Challenge of a Systematized Biblical Theology of Mission: Missiological Insights from the Gospel of John.” Missiology: An International Review 23, no. 4 (October 1995): 445-464. 
Köstenberger, Andreas J. John. Grand Rapids, MI: Baker Academic, 2004.

Kraft, Charles H. "Appropriate Contextualization of Spiritual Power." In Appropriate Christianity, 375-395. Pasadena, CA: William Carey, 2005. . Christianity in Culture: A Study in Biblical Theologizing in CrossCultural Perspective. Maryknoll, NY: Orbis books, 2005. . "Contextualization in Three Crucial Dimensions." In Appropriate Christianity, 99-115. Pasadena, CA: William Carey, 2005.

. "Culture, Worldview and Contextualization." In Perspectives on the World Christian Movement: A Reader, edited by Ralph D. Winter and Steven C. Hawthorne, 400-406. Pasadena, CA: Institute of International Studies, 2009. . "Spiritual Power: A Missiological Issue.” In Appropriate Christianity, 361-374. Pasadena, CA: William Carey, 2005.

. "Three Encounters in Christian Witness." In Perspectives on the World Christian Movement, edited by Ralph D. Winter and Steven C. Hawthorne, 445-469. Pasadena, CA: Institute of International Studies, 2009. . Worldview for Christian Witness. Pasadena, CA: William Carey, 2008.

Kraft, Charles H., and Marguerite G. Kraft. "Communicating and Ministering the Power of the Gospel Cross-Culturally: The Power of God for Christians Who Ride Two Horses." In The Kingdom and the Power, edited by Gary S. Greig and Kevin N. Springer, 345-356. Ventura, CA: Regal Books, 1993.

Kwast, Lloyd E. "Understanding Culture." In Perspectives on the World Christian Movement, edited by Ralph D. Winter and Steven C. Hawthorne, 397-399. Pasadena, CA: Institute of International Studies, 2009.

Labouret, Henri. Les Tribus du Rameau Lobi. Paris, France: Institut d'Ethnologie, 1931.

Launius, Roger D. "An Ambivalent Rejection: Baptism for the Dead and the Reorganized Church Experience." Dialogue: A Journal of Mormon Thought 23, no. 2 (Summer 1990): 61-84.

The Lausanne Committee for World Evangelization. "The Willowbank Report.” In Perspectives on the World Christian Movement: A Reader, edited by Ralph D. Winter and Steven C. Hawthorne, 506-528. Pasadena, CA: Institute of International Studies, 2009.

Lewis, H. David. Christian Theism. Edinburgh, Scotland: Clark, 1984. 
"A Living Soul" [Gen 2:7]. Seventh-day Adventist Bible Commentary. Rev. ed. Edited by Francis D. Nichol. Washington, DC: Review \& Herald, 1976-1980. 1:223.

Love, Richard D. "Church Planting Among Folk Muslims." International Journal of Frontier Missions 11, no. 2 (April 1994): 87-91.

. "Power Encounter Among Folk Muslims: An Essential Key of the Kingdom." International Journal of Frontier Missions 13, no. 4 (OctoberDecember 1996): 193-195.

Luzbetak, Louis J. The Church and Cultures: New Perspectives in Missiological Anthropology. Maryknoll, NY: Orbis Books, 1988.

Macchia, Frank D. "Towards Individual and Communal Renewal: Reflections on Luke's Theology of Conversion.” Ex Auditu 25 (2009): 92-105.

Magesa, Laurenti. African Religion: The Moral Traditions of Abundant Life. Maryknoll, NY: Orbis Books, 1997.

Mathema, Zacchaeus. "Towards an Understanding of the African Worldview." In The Church, Culture and Spirits: Adventism in Africa, edited by Kwabena Donkor, 37-48. Silver Spring, MD: The Biblical Research Institute, General Conference of Seventh-day Adventists, 2011.

Mazama, Ama. "Lobi." Encyclopedia of African Religion. Edited by Molefi Kete Asante and Ama Mazama. Los Angeles, CA: SAGE, 2009. 1:382-383. . "Marriage." Encyclopedia of African Religion. Edited by Molefi Kete Asante and Ama Mazama. Los Angeles, CA: SAGE, 2009. 1:409-411.

Mbiti, John S. African Religion \& Philosophy. Oxford, UK: Heinemann, 1990. . Concepts of God in Africa. London: SPCK, 1970.

Metzger, Paul Louis. "Christ, Culture, and the Sermon on the Mount Community." Ex Auditu 23 (2007): 22-46.

Milgrom, Jacob. Leviticus 17-22. The Anchor Bible. New York: Doubleday, 2000.

Moltmann, Jürgen. The Church in the Power of the Spirit: A Contribution to Messianic Ecclesiology. London, UK: SCM Press, 1977.

Moreau, A. Scott. “Syncretism.” In Evangelical Dictionary of World Mission, 924-925. Grand Rapids, MI: Baker Books, 2000. 
M'Passou, Denis. "The Continuing Tension between Christianity and Rites of Passage in Swaziland." In Rites of Passage in Contemporary Africa: Interaction between Christian and African Traditional Religions, edited by James L. Cox, 15-33. Cardiff, UK: Cardiff Academic Press, 1998.

Muck, Terry, and Frances S. Adeney. Christianity Encountering World Religions: The Practice of Mission in the Twenty-First Century. Grand Rapids, MI: Baker Academic, 2009.

Mullins, Mark R., "Syncretistic Movements." Dictionary of Asian Christianity, edited by Scoot W. Sunquist, 809-810. Grand Rapids, MI: William B. Eerdmans, 2001.

Musasiwa, R. "Contextualization.” Dictionary of Mission Theology. Edited by John Corrie. Downers Grove, IL: InterVarsity Press, 2007. 66-71.

Myerhoff, Barbara G., Linda A. Camino, and Edith Turner. "Rites of Passage: An Overview." The Encyclopedia of Religion. Edited by Mircea Eliade New York: Macmillan, 1986. 12:380-386.

Neely, Alan. "Incarnational Mission.” In Evangelical Dictionary of World Mission, edited by A. Scott Moreau, 474-475. Grand Rapids, MI: Baker Books, 2000.

Niebuhr, Richard H. Christ and Culture. New York: Harper \& Brothers, 1951.

Nthamburi, Zablon. "Making the Gospel Relevant Within the African Context and Culture." African Ecclesial Review 25, no. 3 (June 1983): 162-171.

Nürnberger, Klaus. "Ancestor Veneration in the Church of Christ?" Journal of Theology for Southern Africa, no. 129 (November 2007): 54-69.

Nxumalo, Jabulani A. "Christ and Ancestors in the African World: A Pastoral Consideration." Journal of Theology for Southern Africa, no. 32 (September 1980): 3-21.

Oates, Wayne E. When Religion Gets Sick. Philadelphia, PA: Westminster Press, 1970.

Okorocha, Eunice. "Cultural Issues and the Biblical Message." Africa Bible Commentary. Edited by Tokunboh Adeyemo. Grand Rapids, MI: Zondervan, 2006. 1467-1468.

Ott, Craig, Stephen J. Strauss, and Timothy C. Tennent. Encountering Theology of Mission: Biblical Foundations, Historical Developments, and Contemporary Issues. Grand Rapids, MI: Baker Academic, 2010. 
Ovesen, Jan. "Initiation: A Folk Model among the Lobi." In Personhood and Agency: The Experience of Self and Others in African Cultures, edited by Michael Jackson and Ivan Karp, 149-166. Washington, DC: Smithsonian Institution Press, 1990.

Parrinder, Edward Geoffrey. Religion in Africa. Baltimore, MD: Penguin Books, 1969.

Parsenios, G. L. "Incarnation." Dictionary of Jesus and the Gospels. Edited by Joel B. Green. Downers Grove, IL: IVP Academic, 2013. 399-400.

Partain, Jack. "Christians and Their Ancestors: A Dilemma of African Theology." The Christian Century 103, no. 36 (November 26, 1986): 1066-1069.

Partridge, Christopher. Introduction to World Religions. Minneapolis, MN: Fortress Press, 2005.

Père, Madeleine. Les Lobi: Tradition et Changement. Tome 1. Laval, France: Editions Siloë, 1988.

Pierson, Paul E. The Dynamics of Christian Mission: History through a Missiological Perspective. Pasadena, CA: William Carey International University Press, 2009.

Pilch, John. Introducing the Cultural Context of the Old Testament. Mahwah, NJ: Paulist Press, 1991.

Pocock, Michael. "Introduction: An Appeal for Balance." In Missiology and the Social Sciences: Contributions, Cautions and Conclusions, edited by Edward Rommen and Gary Corwin, 7-18. Pasadena, CA: William Carey, 1996.

Pocock, Michael, Gailyn Van Rheenen, and Douglas McConnell. The Changing Face of World Mission: Engaging Contemporary Issues and Trends. Grand Rapids, MI: Baker Academic, 2005.

Pooda, Hervé Sansan. La Mort Comme Voyage Vers L'Au-delà chez les Lobi d'Afrique de l'Ouest: Une Lecture Africaine de la Bible en Jean 11:1-44. Sarrebruck, Germany: Editons Universitaires Européennes, 2010.

Ray, Benjamin C. African Religions: Symbol, Ritual, and Community. Englewood Cliffs, NJ: Prentice-Hall, 1976.

Reiss, Moshe. "Adam: Created in the image and Likeness of God." Jewish Bible Quarterly 39, no. 3 (July-September 2011): 181-186. 
Reynolds, B. E. "Logos." Dictionary of Jesus and the Gospels. Edited by Joel B. Green. Downers Grove, IL: IVP Academic, 2013. 523-526.

Rogers, Glenn. The Bible Culturally Speaking: The Role of Culture in the Production, Presentation and Interpretation of God's Word. Bedford, TX: Mission and Ministry Resources, 2004.

Rogerson, John, and Philip Davies. The Old Testament World. Englewood Cliffs, NJ: Prentice-Hall, 1989.

Rooker, Mark F. The New American Commentary: Leviticus. Nashville, TN: Broadman \& Holman, 2000.

Saako, Mahmoud Malik, Samuel N. Nkumbaan, Christopher Boatbil Sormiteyema, and Azerikatoa D. Ayoung, "Birifoh Belief System: Perspectives from Birifoh-Sila Yiri, Upper West Region, Ghana." Research on Humanities and Social Sciences 4, no. 3 (2014): 86-99.

Sadananda, D. R., "The Johannine Logos: Interpreting Jesus in a Multi-Religious Context." In Reformed Theology, edited by Wallace M. Alston Jr. and Michael Welker, 349-372. Grand Rapids, MI: William B. Eerdmans, 2007.

Sanou, Boubakar. "Motivating and Training the Laity to Increase Their Involvement in Ministry in the Ouaga-Center Adventist Church in Burkina Faso." DMin dissertation, Andrews University, 2010.

Schaller, Lyle E. The Change Agent: The Strategy of Innovative Leadership. Nashville, TN: Abingdon Press, 1972.

Schrotenboer, Paul G. "Christ and Culture.” Evangelical Review of Theology 22 (October 1998): 316-336.

Shmidt, Lynn D. “How Much Syncretism Is Allowed?” Evangelical Mission Quarterly (January 2013): 26-33.

Shorter, Aylward. "Conflicting Attitudes to Ancestor Veneration in Africa." African Ecclesial Review 11, no. 1 (January 1969): 27-37.

Shujaa, Mwalimu J. "Initiation.” Encyclopedia of African Religion. Edited by Molefi Kete Asante and Ama Mazama. Los Angeles, CA: SAGE, 2009. 1:342-344.

Smith, Edwin W. "The Idea of God among South African Tribes.” In African Ideas of God: A Symposium, 78-134. London, UK: Edinburgh House Press, 1950.

Smith, Henry N. "A Typology of Christian Responses to Chinese Ancestor Worship." Journal of Ecumenical Studies 26, no. 4 (Fall 1989): 628-647. 
Sparks, Kent L. "Religion, Identity and Origins of Ancient Israel." Religion Compass 1, no. 6 (2007): 587-614.

"The Spirit" [Eccl 12:7]. Seventh-day Adventist Bible Commentary. Rev. ed. Edited by Francis D. Nichol. Washington, DC: Review \& Herald, 1976-1980. 3:1104.

Sprinkle, Joe M. "The Rationale of the Laws of Clean and Unclean in the Old Testament." Journal of the Evangelical Theological Society 43, no. 2 (2000): 637-657.

Standhartinger, Angela. "“What Women Were Accustomed to Do for the Dead Beloved by Them' (Gospel of Peter 12.50): Traces of Laments and Mourning Rituals in Early Easter, Passion, and Lord's Supper Traditions." Journal of Biblical Literature 129, no. 2 (2010): 559-574.

Steinberg, Naomi. "Exodus 12 in Light of Ancestral Cult Practices." In The Family in Life and in Death: The Family in Ancient Israel, edited by Patricia DutcherWalls, 89-105. New York: T \& T Clark, 2009.

Stott, John R. W. "The Living God Is a Missionary God." In Perspectives on the World Christian Movement, edited by Ralph D. Winter and Steven C. Hawthorne, 3-9. Pasadena, CA: Institute of International Studies, 2009.

Tennent, Timothy C. Invitation to World Missions: A Trinitarian Missiology for the Twenty-First Century. Grand Rapids, MI: Kregel, 2010.

Tenney, Merrill C. Exploring New Testament Culture: A Handbook of New Testament Times. Iowa Falls, IA: Word Bible Publishers, 2000.

Thomas, P. B. "Any Other Name? A Response to Dialogical Theology.” In Many Other Ways? Questions of Religious Pluralism, edited by M. Bage, R. Hedlund, P. B. Thomas, Martin Alphonse, and George David, 28-43. New Delhi, India: Printstman, 1992.

Tippett, Alan. People Movements in Southern Polynesia: Studies in the Dynamics of Church-planting and Growth in Tahiti, New Zealand, Tonga, and Samoa. Chicago: Moody Press, 1971.

Travis, John, and Anna Travis. "Deep-Level Healing Prayer in Cross-Cultural Ministry: Models, Examples, and Lessons." In Paradigm Shifts in Christian Witness: Insights from Anthropology, Communication, and Spiritual Power, edited by Charles E. Van Engen, Darrell Whiteman, and J. Dudley Woodberry, 106-115. Maryknoll, NY: Orbis Books, 2008. 
Triebel, Johannes. "Living Together with the Ancestors: Ancestor Veneration in Africa as a Challenge for Missiology." Missiology: An International Review 30, no. 2 (April 2002): 187-197.

Turner, Victor. The Ritual Process: Structure and Anti-Structure. New Brunswick, NJ: Aldine Transaction, 2008.

Van Rheenen, Gailyn. Communicating Christ in Animistic Contexts. Pasadena, CA: William Carey Library, 1991.

Van Rheenen, Gailyn. "Modern and Postmodern Syncretism in Theology and Mission." In The Holy Spirit and Mission Dynamics, edited by C. Douglas McConnell, 164-207. Pasadena, CA: William Carey, 1997.

Van Til, Henry R. The Calvinistic Concept of Culture. Grand Rapids, MI: Baker Academic, 2001.

Van Velsor, Ellen, and Wilfred H. Drath. "A Lifelong Developmental Perspective on Leader Development." In Handbook of Leadership Development, edited by Cynthia D. McCauley and Ellen Van Velsor, 383-414. San Francisco, CA: Jossey-Bass, 2004.

Vicedom, Georg F. The Mission of God: An Introduction to a Theology of Mission. St. Louis, MO: Concordia, 1965.

Wagner, C. Peter. "Missiology and Spiritual Power." In Paradigm Shifts in Christian Witness: Insights from Anthropology, Communication, and Spiritual Power, edited by Charles E. Van Engen, Darrell Whiteman, and J. Dudley Woodberry, 91-97. Maryknoll, NY: Orbis Books, 2008.

. Spiritual Warfare Strategy: Confronting Spiritual Powers. Shippensburg, PA: Destiny Image Publishers, 1996.

Wall, Andrew F. The Cross-Cultural Process in Christian History. Maryknoll, NY: Orbis Books, 2002.

Wan, Enoch. "Critiquing the Model of the Traditional Western Theology and Calling for Sino-Theology." Chinese Around the World, November 1999, 12-17.

Weerasingha, Tissa. "Karma and Christ: Opening Our Eyes to the Buddhist World." International Journal of Frontier Missions 10, no. 3 (July 1993): 103-104.

White, Ellen G. The Desire of Ages. Mountain View, CA: Pacific Press, 1940. . Ministry of Healing. Mountain View, CA: Pacific Press, 1909. . My Life Today. Hagerstown, MD: Review and Herald, 1980. 
White, Ellen G. Selected Messages Book 1. Washington, DC: Review and Herald, 1958.

White, Joel R. "“Baptized on Account of the Dead': The Meaning of 1 Corinthians 15:29 in Its Context." Journal of Biblical Literature 116, no. 3 (Fall 1997): 487-499.

Wimber, John, and Kevin Springer. Power Evangelism. Ventura, CA: Regal, 2009.

Woodberry, J. Dudley. "Power and Blessing: Keys to Relevance to a Religion as Lived." In Paradigm Shifts in Christian Witness: Insights from Anthropology, Communication, and Spiritual Power, edited by Charles E. Van Engen, Darrell Whiteman, and J. Dudley Woodberry, 98-105. Maryknoll, NY: Orbis Books, 2008.

Zvarevashe, Ignatius M. "The Problem of Ancestors and Inculturation." African Ecclesial Review 29, no. 4 (August 1987): 242-251. 